\title{
Analysis of the levelized cost of green hydrogen production for very heavy
} vehicles in New Zealand

\section{By}

Rapha Julysses Enero Perez

Supervisors:

Prof Alan Brent

Dr James Hinkley

\begin{abstract}
A thesis
submitted to the Victoria University of Wellington in fulfilment of the requirements for the degree of

Master of Science by Thesis in Electronics and Computer Systems
\end{abstract}




\begin{abstract}
This study examined the feasibility of green hydrogen as a transport fuel for the very heavy vehicle (VHV) fleet in New Zealand. Green hydrogen is assumed to be produced through water electrolysis using purely renewable energy (RE) as an electricity source. This study chose very heavy vehicles as a potential market for green hydrogen, because it is considered "lowhanging fruit" for hydrogen fuel in a sector where battery electrification is less feasible. The study assumed a large-scale, decentralized, embedded (dedicated) grid-connected hydrogen system of production using polymer electrolytic membrane (PEM) electrolysers. The analysis comprised three steps. First, the hydrogen demand was calculated. Second, the additional RE requirement was determined and compared with consented, but unbuilt, capacity. Finally, the hydrogen production cost was calculated using the concept of levelized cost. A sensitivity analysis, cost reduction scenarios, and the implications for truck ownership costs were also undertaken.
\end{abstract}

The results indicate an overall green hydrogen demand for VHVs of 71 million $\mathrm{kg}$, or $8.5 \mathrm{PJ}$, per year, compared to the $14.7 \mathrm{PJ}$ of diesel fuel demand for the same VHV travelled kilometres. The results also indicate that the estimated 9,824 GWh of RE electricity from consented, yet unbuilt, RE projects is greater than the electricity demand for green hydrogen production, which was calculated to be $4,492 \mathrm{GWh}$. The calculated levelized hydrogen cost is $\mathrm{NZ} \$ 8.42 / \mathrm{kg}$. Electricity cost was found to be the most significant cost parameter for green hydrogen production. A combined annual cost reduction rate of $3 \%$ for CAPEX and $4 \%$ for electricity translates to a hydrogen cost reduction of $30 \%$ in 10 years and more than $50 \%$ in 20 years. 


\section{Acknowledgements}

I started my postgraduate journey along with Theresa Castro. Back then it was wonderful to have a friend to be with, a fellow Filipino, who was also doing a thesis. Shortly after, she finished, and she left. That is when it dawned on me how this journey can be very solitary.

A few months down the road and I experienced homesickness and culture shock, with health and wellbeing issues over the course of my studies. There was a time that my hometown was hit by four major earthquakes. And just two weeks after my scheduled submission, my grandfather, Lawrencio Enero, passed away. He waited for me to finish my studies and go home, until he could wait no more.

But despite the challenges, I am thankful for the handful of people who have extended help and support throughout this academic journey. I am truly grateful for my two supervisors, Alan Brent and James Hinkley, for their unwavering support throughout this thesis journey. I met a few friends in Wellington. I met Ernest Caballero, Aaron John Mendoyos, and Wisdom Errua. My flatmate Hanny John Mediodia, who is doing a PhD and has always supported me with my academic concerns. I've met Filipino friends whom I could hang out with. I've met friends from church at Arise and Christian friends from Student Life, and my scholarship friends with whom I could share experiences. When everyone was busy in our academic work, the coffee hours were the only times when we could to catch up with each other. Thank you to the Student Learning team, to Kirsten Reid, who organised several sessions to help us with our studies, and to the scholarship team composed of Clemmie Newton, Stefanie Fischer, Ryan Stuart, Vivian Wei, Ha Vo and Anthony Chun, who always went above and beyond to provide highly personalised care and support. These people have really made Wellington a home away from home. To MFAT, thank you so much for selecting me as one of the twenty Filipinos to be awarded a New Zealand Scholarship in 2019. To my mother, Julita, my father, Ulysses, my siblings Peter Paul, John Paul, and Lawrence Jireh. The year that passed by was the most difficult time away from family. But because of their love, I made it this far. And of course, to Almighty God, thank you for Your grace and goodness. To You be all the glory and honour, amen.

We are faced with issues of global significance. For one, climate change is a global phenomenon that doesn't recognise borders, governments, and politics, etc. As a future young leader, I have responsibilities. I have a family to feed, a country to serve and a dream to pursue. My victories in Wellington are not just to hang on walls or get dusted on shelves; I will propel this into action. The friendships and bonds that I made here are testament that the world is inclusive. My education at Victoria University of Wellington will not return to the world empty handed. 


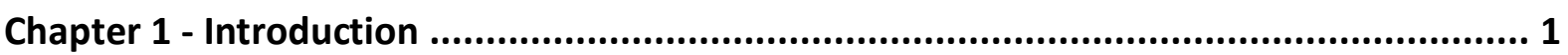

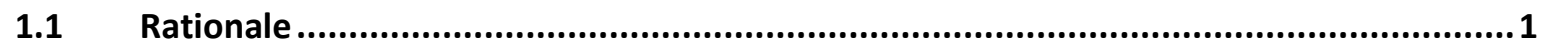

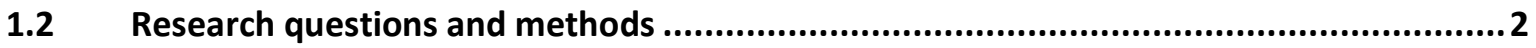

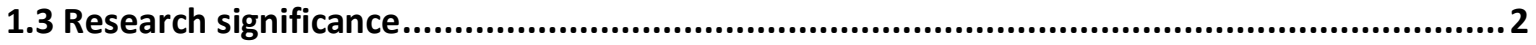

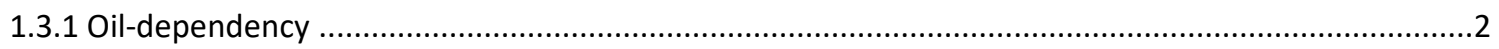

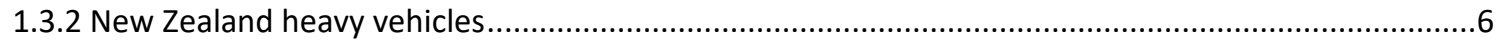

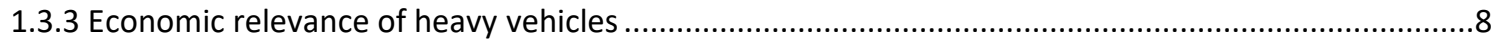

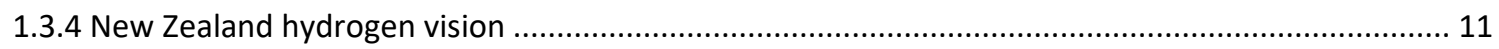

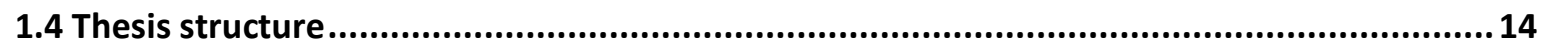

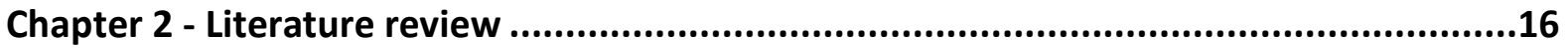

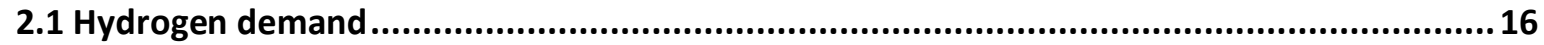

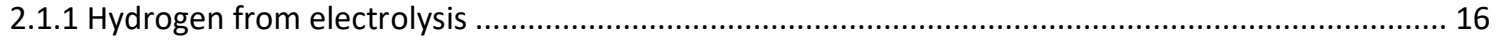

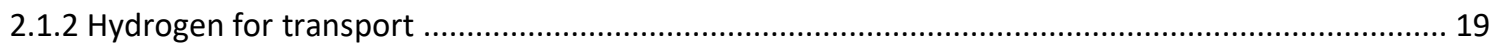

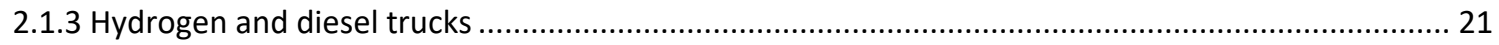

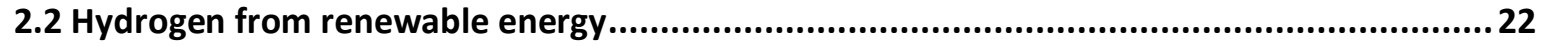

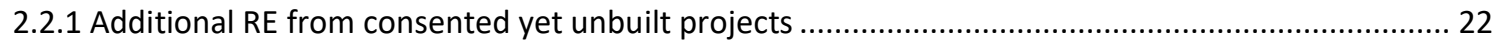

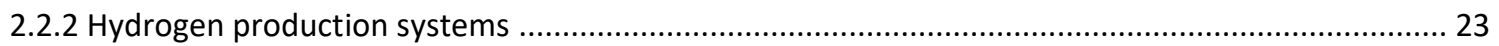

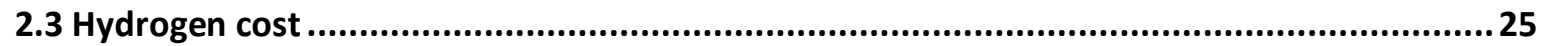

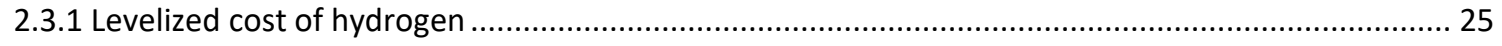

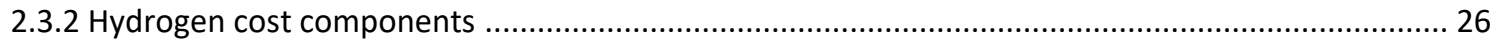

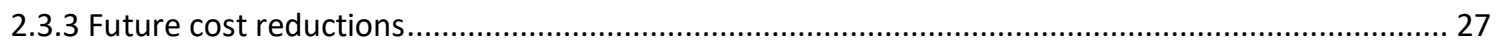

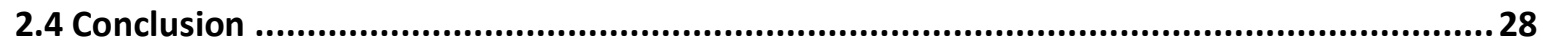

Chapter 3 - Methodology and initial results ...............................................................30

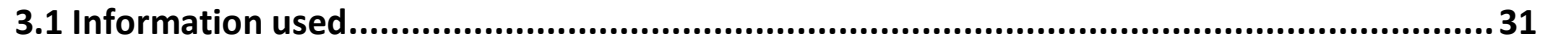

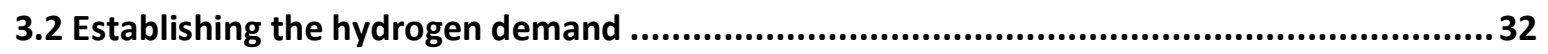

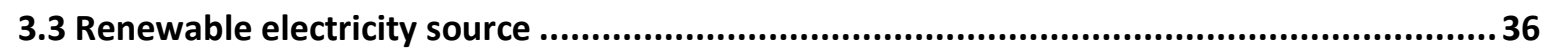

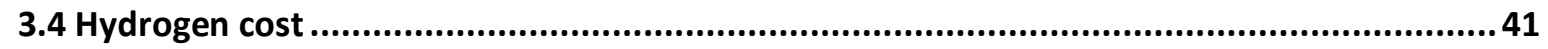

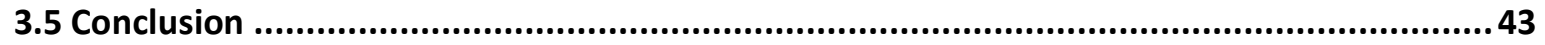

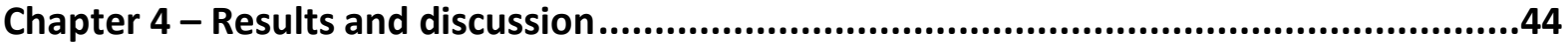

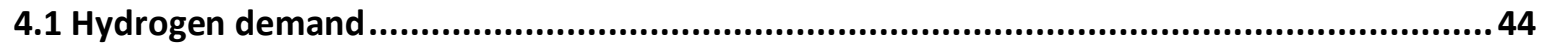

4.2 Renewable energy supply ...........................................................................45 


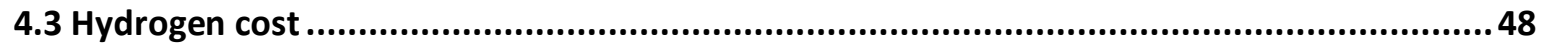

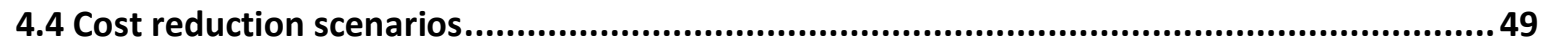

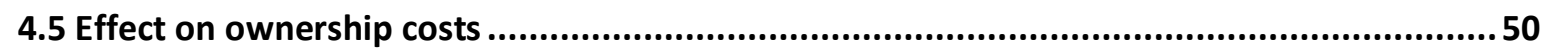

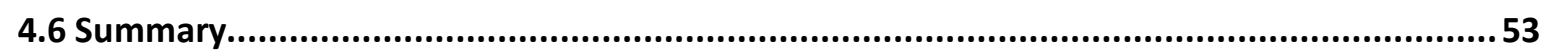

Chapter 5 - Conclusions and recommendations ....................................................54

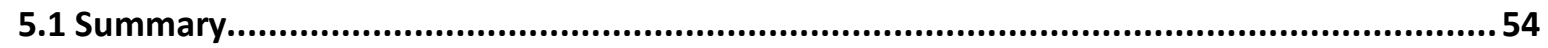

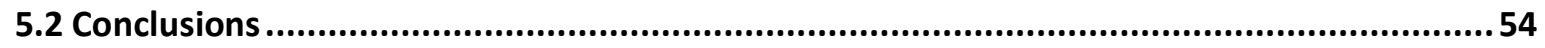

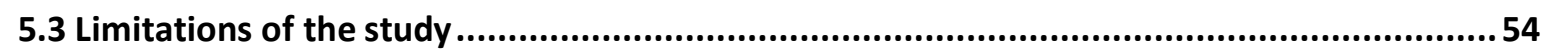

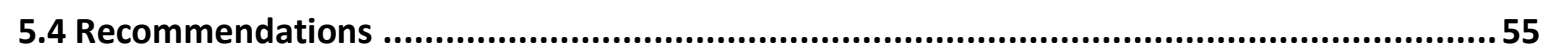

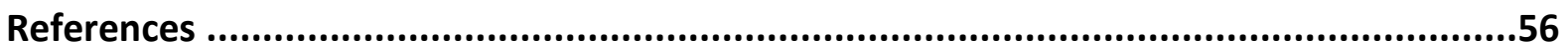




\section{List of Tables}

Table 1. 1. Global development in fuel cell vehicles. From IEA Hydrogen (2017) and Hydrogen Council (2017)

Table 2.1. Electrolyser characteristics. From Manage, Hodgson, Milligan, Simons, and Brett (2011)

Table 2.2. Technical specifications for PEM electrolysers

Table 2.3. Technical specifications of the hydrogen trucks. From ESORO (2017) and Hyundai

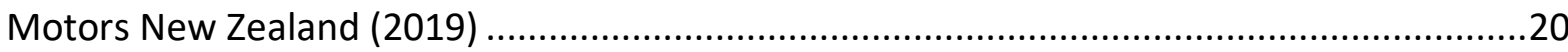

Table 2.4. HRS targets in several countries. From IEA (2017) ..........................................25

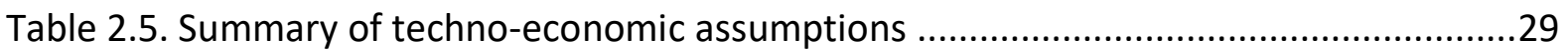

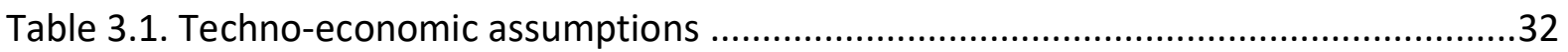

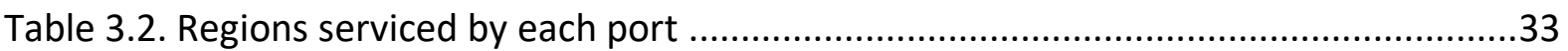

Table 3.3. Annual (2017) diesel demand for VHVs per region ...........................................34

Table 3.4. Estimated equivalent annual (2017) kilometre travel distance of the VHV fleet...35

Table 3.5. Estimated annual (2017) net hydrogen demand for VHVs ...................................36

Table 3.6. Estimated annual (2017) electrolytic energy consumption per region ..................37

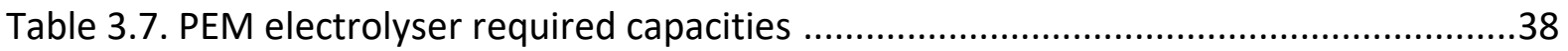

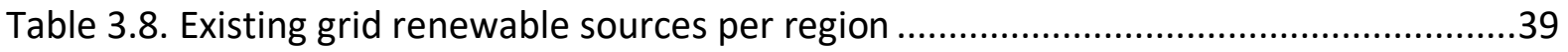

Table 3.9. Consented yet unbuilt renewable energy projects per region ..............................40

Table 3.10. Regional electrolyser energy demand and additional renewable generation .....41

Table 3.11. Hydrogen model assumptions derived from Concept Consultancy (2019) .........42

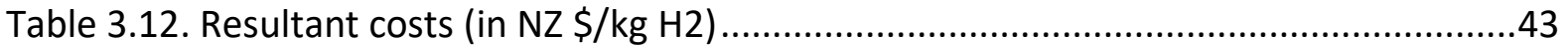

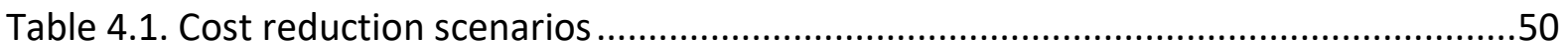

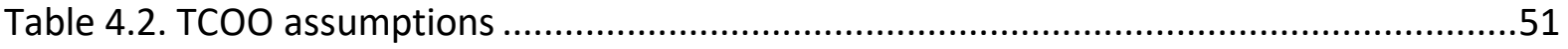




\section{List of Figures}

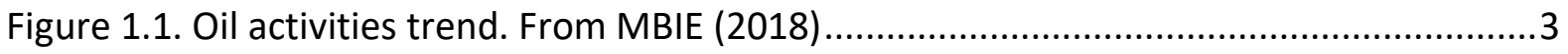

Figure 1.2. New Zealand oil balances in 2017. From MBIE (2018) .......................................... 4

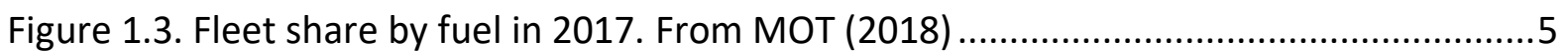

Figure 1.4. Transport oil profile in 2017. From MBIE (2017) ...................................................5

Figure 1.5. Heavy vehicles by mass (kg). From Ministry of Transport (2018) .........................6

Figure 1.6. New Zealand state highway network. From Te Ara Online Encyclopedia (2016) ...7

Figure 1.7. Regional heavy vehicle TKM on state highways in 2017. From NZTA (2018).........8

Figure 1.8. Heavy traffic index and GDP. From ANZ $(2019$, p.1) ........................................

Figure 1.9. Comparison of GDP and TKM growth from 2001 to 2017. From NZTA (2018) .......9

Figure 1.10. Comparison of population and road freight in tons (a) and ton-kilometres (b) in

2014. From Stats NZ (2019) and Deloitte (2018) ............................................................11

Figure 1.11. Complementary roles of battery electric and hydrogen fuel in the transport fleet

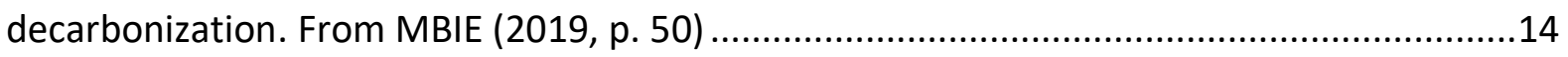

Figure 2.1. Basic diagram for electrolysis. From Siemens $(2018$, p. 3) .................................16

Figure 2.2. Alkaline and PEM electrolysers. From Lettenmeier $(2019$, p. 5) ........................18

Figure 2.3. Total RE and non-RE electricity generation. From MBIE (2018, p. 54)................22

Figure 2.4. Cost projections for PEM electrolysers from 1992 through to 2030. From Saba et

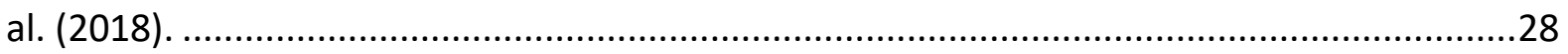

Figure 3.1. Methodology schematic diagram ................................................................ 30

Figure 3.2. Port offtakes for 2107 calendar year. From MBIE (2018; p. 35)..........................33

Figure 4.1. Regional demand for hydrogen fuel ...........................................................45

Figure 4.2. Electrolyser capacity in numbers of HyLYZER (5MW) and SilYZER (1.25 MW) units

Figure 4.3. Sensitivity of electrolyser capacity to utilization rate

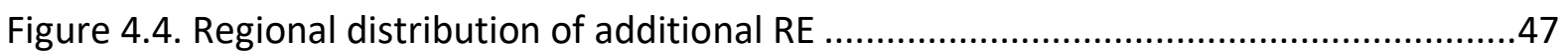

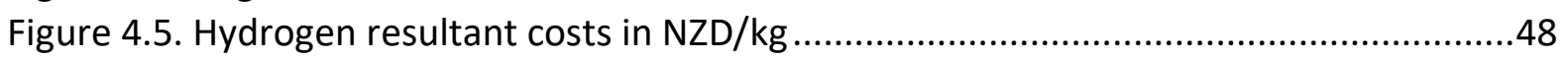

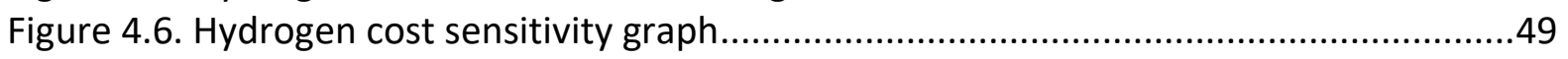

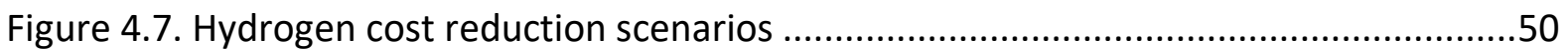

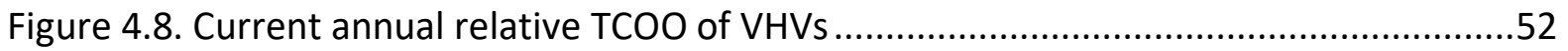

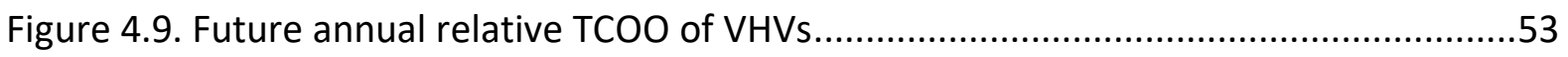




\section{List of Abbreviations}

$\begin{array}{ll}\mathrm{CO}_{2} & \text { Carbon dioxide } \\ \text { CSIRO } & \text { Commonwealth Scientific and Industrial Research Organisation (Australia) } \\ \text { DCF } & \text { Discounted cash flow } \\ \text { EIA } & \text { Energy Information Administration (U.S.) } \\ \text { FCEV } & \text { Fuel cell electric vehicle } \\ \text { FCH JU } & \text { Fuel Cells and Hydrogen Joint Undertaking (E.U.) } \\ \text { GDP } & \text { Gross domestic product } \\ \text { IEA } & \text { International Energy Agency } \\ \text { IRENA } & \text { International Renewable Energy Agency } \\ \text { kWh } & \text { Kilowatt hour } \\ \text { LCOH } & \text { Levelized cost of hydrogen } \\ \text { MBIE } & \text { Ministry of Business, Innovation and Employment (New Zealand) } \\ \text { Mmbbls } & \text { Million barrels } \\ \text { MOT } & \text { Ministry of Transport (New Zealand) } \\ \text { MT } & \text { Million tonnes } \\ \text { NZ } & \text { New Zealand } \\ \text { NZS } & \text { New Zealand dollars } \\ \text { NZFS } & \text { New Zealand Freight Study } \\ \text { NZTA } & \text { New Zealand Transport Agency } \\ \text { PEM } & \text { Proton exchange membrane } \\ \text { PJ } & \text { Petajoules } \\ \text { RE } & \text { Renewable energy } \\ \text { RUC } & \text { Road user charges } \\ \text { SH } & \text { State highway (New Zealand) } \\ \text { SOEC } & \text { Solid oxide electrolyser cell } \\ \text { TCOO } & \text { Total cost of ownership } \\ \text { TKM } & \text { Tonne kilometre } \\ \text { TWA } & \text { Time weighted average } \\ \text { VHV } & \text { Very heavy vehicle } \\ \text { WACC } & \text { Weighted average capital cost } \\ & \end{array}$




\section{Chapter 1 - Introduction}

This chapter discusses the rationale of the study, followed by the research questions and the research significance. The chapter is concluded with a summary of the thesis structure.

\subsection{Rationale}

Climate change is a global phenomenon that countries have to acknowledge, since its effects are felt regardless of national borders. Global warming, variability in climatic conditions and massive depletion of biodiversity are some of the consequences of climate change. As a result, countries are initiating efforts to combat anthropogenic climate change by abating greenhouse gas emissions. Initiatives for sectoral decarbonization are happening on a global scale. In the energy sector, the continued increase and improvement of renewable energy technologies prove to be useful in decarbonizing the electricity source and provide energy security. But there is still work that needs to be done to decarbonize the transport sector. This is one of the sectors where green hydrogen aims to provide a decarbonization option (Hydrogen Council, 2020; MBIE, 2019a).

Hydrogen is attracting significant interest in New Zealand. With potential applications including energy storage, industrial heating, chemical feedstock, and green fuel, hydrogen holds a vast potential as an alternative energy vector. The New Zealand Government recognizes the need to explore hydrogen in order to meet energy security and climate change commitments, such as the 2015 Paris agreement and net-zero carbon emissions by 2050 (MBIE, 2019b). A high share of renewables in the electricity mix (International Energy Agency, 2017) places New Zealand in a position to produce green hydrogen from renewable electricity sources through electrolysis.

As stated before, one of the sectors where hydrogen can play a role as a clean energy vector is transport. In 2017, road transport accounted for about 14.5 million tonnes of $\mathrm{CO}_{2}$ equivalent, or around 18\%, of total greenhouse gas emissions in New Zealand (Ministry for the Environment, 2019). Emissions growth in the road transport sector is responsible for an overall increase of New Zealand's greenhouse gas emissions. In particular, the heavy vehicle fleet is considered "hard to decarbonize", where the penetration of battery technology is difficult (Energy Transitions Commission, 2018).

This paper examines the feasibility of green hydrogen as a transport fuel for Very Heavy Vehicles (VHVs) in New Zealand. VHVs are defined as those vehicles with a mass that exceeds 30 tonnes (Concept Consultancy, 2019). Green hydrogen fuel is attractive for VHVs for several reasons. First, VHVs tend to have definite travel patterns with routine back-to-base trips, suitable to be serviced by centralized hydrogen refuelling facilities. Second, the growth of heavy traffic follows GDP, since economic growth necessitates road freight activities (ANZ, 2019). Third, heavy vehicles consume diesel, a non-renewable fuel with local prices that are greatly influenced by international price volatility. Therefore, green hydrogen that is produced in New Zealand could potentially decarbonize VHVs without compromising road freight activities in a growing economy. 


\subsection{Research questions and methods}

There is still work that needs to be done on the techno-economics of hydrogen in New Zealand. This is despite the existing production infrastructure in New Zealand for industrial hydrogen. Thus, the overall research objective of this study is to establish a case specific feasibility analysis of green hydrogen fuel in New Zealand. This study specifically looks at the very heavy vehicle (VHV) fleet. Providing a case specific approach determines which technoeconomic components are relevant to the calculation of hydrogen cost. This study also aims to challenge diesel dependence of VHVs by looking at how hydrogen may be a better alternative in terms of efficiency and fuel economy. In order to do this, three questions are addressed:

Question 1: How much hydrogen needs to be produced regionally?

Method 1: Electrolytic hydrogen as a green fuel is proposed to replace diesel fuel in the VHV fleet in New Zealand. This question was addressed by determining the diesel consumed by VHVs. The equivalent green hydrogen fuel demand was calculated from the equivalent travel kilometres made by all VHVs. Demand for green hydrogen fuel was also calculated regionally.

Question 2: Where and how much renewable energy (RE) electricity is required to produce the green hydrogen fuel?

Method 2: Green hydrogen fuel is produced via electrolysis using purely RE sources. Therefore, the demand for green hydrogen fuel for VHVs will drive a significant amount of RE electricity demand. This question was addressed by determining the additional consented, yet unbuilt, RE generating plants. By calculating the RE electricity demand from the green hydrogen production demand, the feasibility of utilising already consented RE projects could be determined.

Question 3: How much will this hydrogen cost?

Method 3: Hydrogen cost was calculated using the concept of levelized cost. Input parameters to the levelized cost of hydrogen $(\mathrm{LCOH})$ include hydrogen demand volume, electricity input demand, electrolyser capital cost, electricity input cost, and operations and maintenance costs. A discounted cash flow analysis using a predetermined discount and system lifetime was also included. Sensitivity analysis was undertaken to determine which input parameters are highly significant to the hydrogen cost.

\subsection{Research significance}

This study is significant in New Zealand for at least four reasons: oil-dependency, the size of the heavy vehicle fleet, and their economic relevance, as well as the country's hydrogen vision.

\subsubsection{Oil-dependency}

A discussion about the oil and diesel consumption profile of NZ is necessary to provide an overview of how oil-dependent the country is, especially the transport sector. This presents 
the opportunity for hydrogen fuel for sectors currently dominated by oil. For transport, the opportunity for hydrogen extends to heavy vehicles in general, not just VHVs.

There is a global trend in terms of an increase in oil demand and a decrease in oil production. The world is expected to see an average increase in oil demand of 1.2 million barrels/day (mb/d) by 2023 (IEA, 2018), driven by a growing world economy. Asia and the Pacific has the greatest increase as the continent is home to fastest growing economies, while Europe is flattening on oil demand. After 2023, however, global oil demand will reduce to $1.0 \mathrm{mb} / \mathrm{d}$. There are indications of shifting to alternative fuels by some countries, especially China, which has concerns over urban air quality. Other factors that influence the demand are the effective implementation of efficiency measures, and significant growth in the use of natural gas as an alternative fuel, especially for buses and trucks (IEA, 2018; Z Energy, 2019). Furthermore, diminishing oil discoveries and a decrease in investment in oil activities are also observed (IEA, 2018). The same downward trend is true in New Zealand. Expenditure on exploration and development was down by 16\% from 2016 to 2017. Production permits were down by $11 \%$ for the same period, and drilling activities had stagnated (MBIE, 2018).

New Zealand is both an importer and exporter of oil in the international market (as can be seen in Figure 1.1 below).

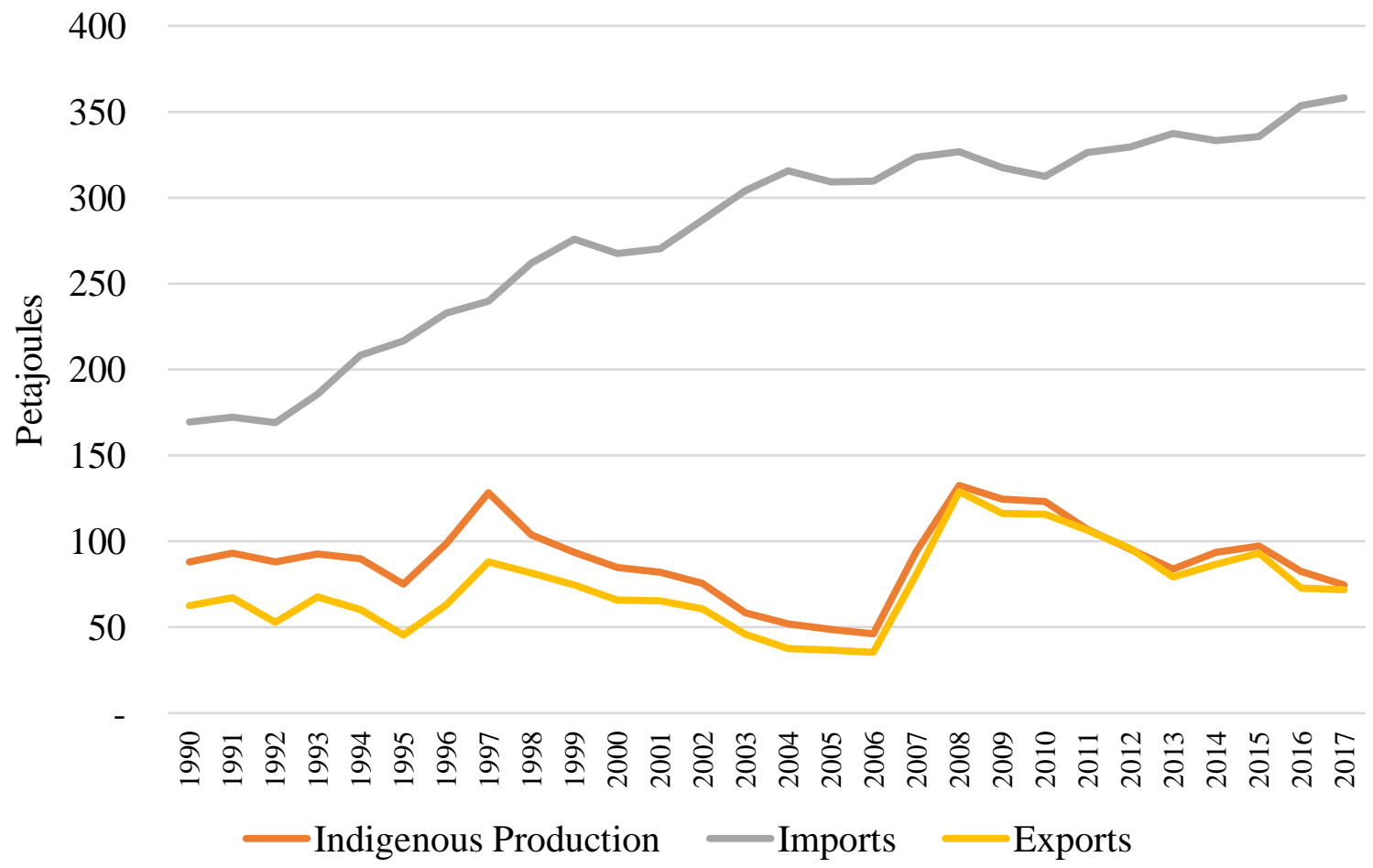

Figure 1.1. Oil activities trend. From MBIE (2018)

It is impacted not just by price volatility, but also by global supply and demand trends. In 2017, New Zealand produced 11.3 million barrels (mmbbls) of crude oil, of which 10.3 mmbbls were exported. Imported crude oil was at $41.7 \mathrm{mmbbls}$. Thus, New Zealand is a net importer of crude oil. There has been a steady growth in oil imports over the years. This is to cope with growing oil demand. The trend in oil exports closely follows indigenous 
production, which has seen a downward curve since 2008. This downward trend can be due to diminishing reserves and slowing domestic oil activities (MBIE, 2018).

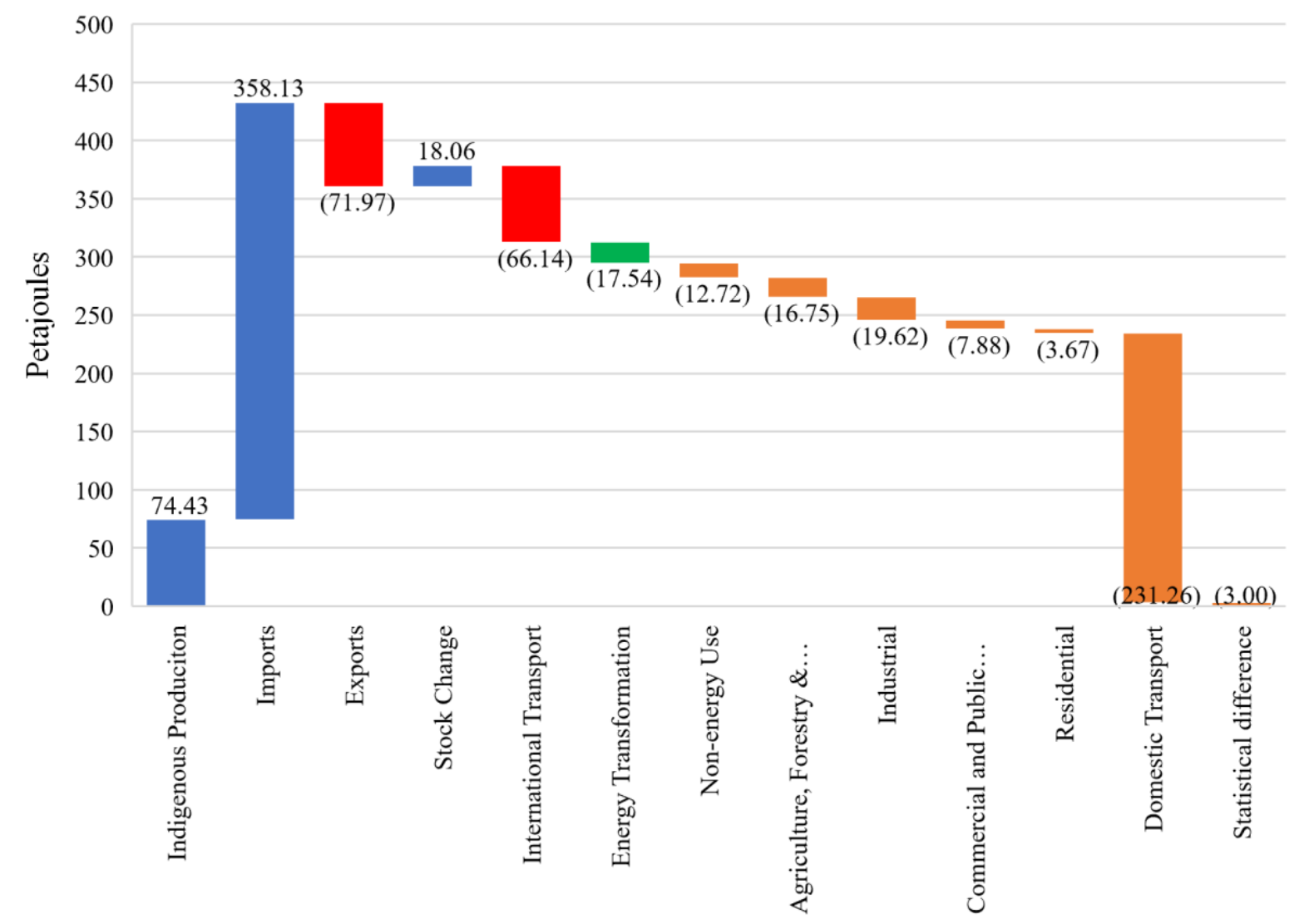

Figure 1.2. New Zealand oil balances in 2017. From MBIE (2018)

Domestic transport is the dominant oil consuming sector in 2017, and grew $6 \%$ from the previous year (MBIE, 2018). It is responsible for $231.26 \mathrm{PJ}$, or $83 \%$, of oil consumption (Figure 1.2). In 2017, the vehicle fleet was composed of $78 \%$ petrol vehicles and $22 \%$ diesel vehicles. The fleet was composed of $91 \%$ light vehicles and about $4 \%$ of heavy vehicles (Figure 1.3). In terms of fleet share by fuel, most light vehicles consume petrol, dominating at $99.9 \%$ of total petrol vehicles. Diesel is consumed by $98 \%$ of heavy vehicles.

However, diesel is the major oil product consumed in the transport sector (Figure 1.4). In terms of fuel volumes consumed, heavy vehicles are responsible for about $51 \%$ of all diesel consumed in the domestic transport sector in the same year (MBIE, 2018). Looking at the fleet share by fuel (as shown in Figure 1.3), 22\% of both light and heavy diesel vehicles are responsible for $49 \%$ of transport oil consumption in 2017. From these figures, there are two key points supporting the reason why heavy vehicles are "low-hanging fruit" for the replacement of diesel by hydrogen fuel. First, despite being fewer in numbers, diesel vehicles dominate the overall transport oil consumption. This means that only a few vehicles hold a large share in the overall diesel consumption. If these diesel trucks can run on hydrogen instead of diesel, a significant portion of New Zealand's domestic oil consumption could be reduced. Second, since there are few diesel heavy vehicles in the fleet, replacing these with hydrogen fuel cell trucks is easier than replacing a large proportion of the light vehicle fleet. 
The gradual adoption of hydrogen fuel cell trucks can happen alongside the gradual fleet retirement of current diesel heavy vehicles.

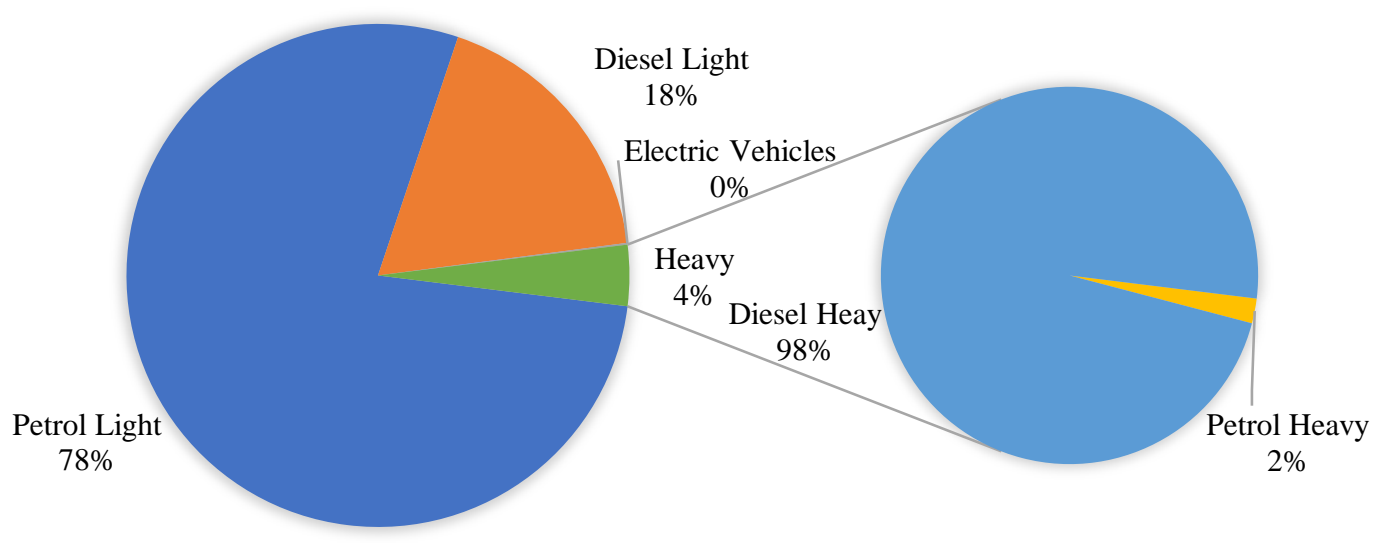

Figure 1.3. Fleet share by fuel in 2017. From MOT (2018)

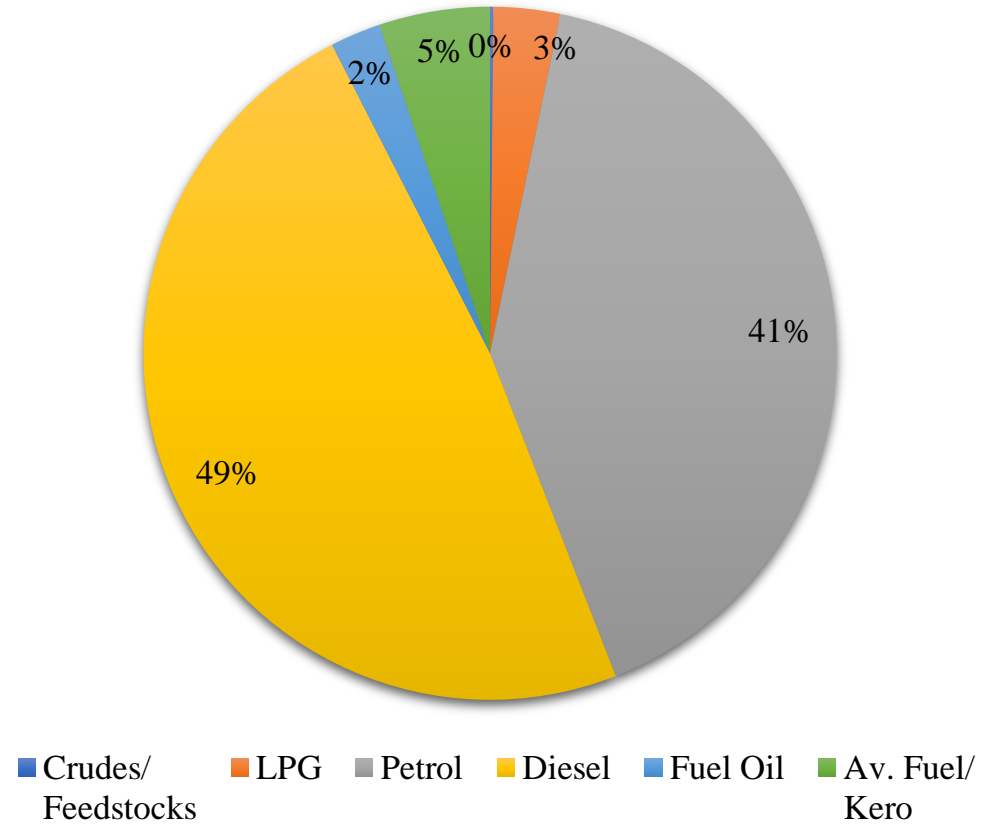

Figure 1.4. Transport oil profile in 2017. From MBIE (2017) 


\subsubsection{New Zealand heavy vehicles}

The heavy vehicle profile in New Zealand consists of three segments: demographics, travel kilometres, and freight information. This discussion aims to define the scope of heavy vehicles in this study as VHVs are the target market for green hydrogen fuel. It also aims to appreciate the role of heavy vehicles in the freight activities in New Zealand by looking at where most of the heavy vehicle traffic occurs. These places are also where population centres are located, and most economic activities take place.

Heavy vehicles have a gross vehicle mass of more than $3,500 \mathrm{~kg}$. These can be classified into medium goods vehicles (more than $3,500 \mathrm{~kg}$ but less than $10,000 \mathrm{~kg}$ ) or heavy goods vehicles (more than $10,000 \mathrm{~kg}$ ). In terms of heavy vehicle fleet share by mass (Figure 1.5), most trucks are concentrated both in the range less than $10,000 \mathrm{~kg}$ and more than 25,000 kg (Ministry of Transport, 2018). The probable reason for this might be the apportioning of freight tasks for short- and long-range travel. Smaller trucks may be used for freight tasks within a city, while larger trucks are used for intercity travelling. Freight tasks are planned economically, reducing travel distances as much as possible by loading and unloading freight from the port nearest to its point of production or use (Deloitte, 2018). In this study, the VHV fleet, weighing more than $30,000 \mathrm{~kg}$, is selected for the analysis. It represents roughly $8 \%$ of the total heavy vehicles in the fleet.
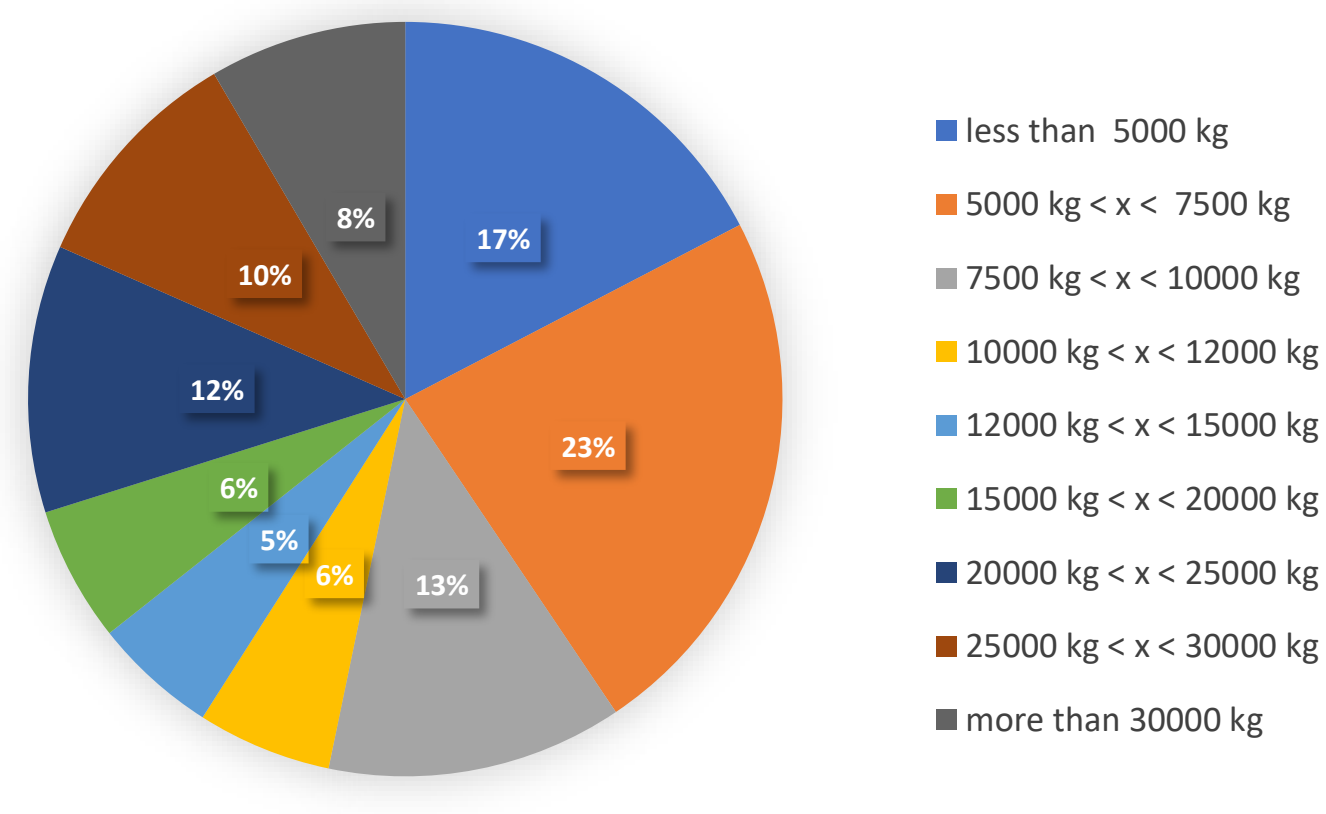

Figure 1.5. Heavy vehicles by mass (kg). From Ministry of Transport (2018)

Some heavy vehicles, especially the "very heavy" ones, tend to be large in size. Because of this, they are only allowed access on certain roads in New Zealand. For intercity travel, it is safe to assume that these vehicles travel along state highways (Figure 1.6). Heavy vehicles pay a certain amount to contribute to maintaining the condition of roads. This is termed the road user charge (RUC), which heavy vehicles pay per $1000 \mathrm{~km}$. Through the payment of RUCs, 
truck and trailer travel is monitored via the measurement of travel kilometres (TKM) (Figure 1.7). Regions with high heavy vehicle traffic volumes include Auckland, Canterbury, Bay of Plenty, and Wellington. These regions have the largest shipping ports and population centres, which are indications of significant freight movements (Deloitte, 2017).

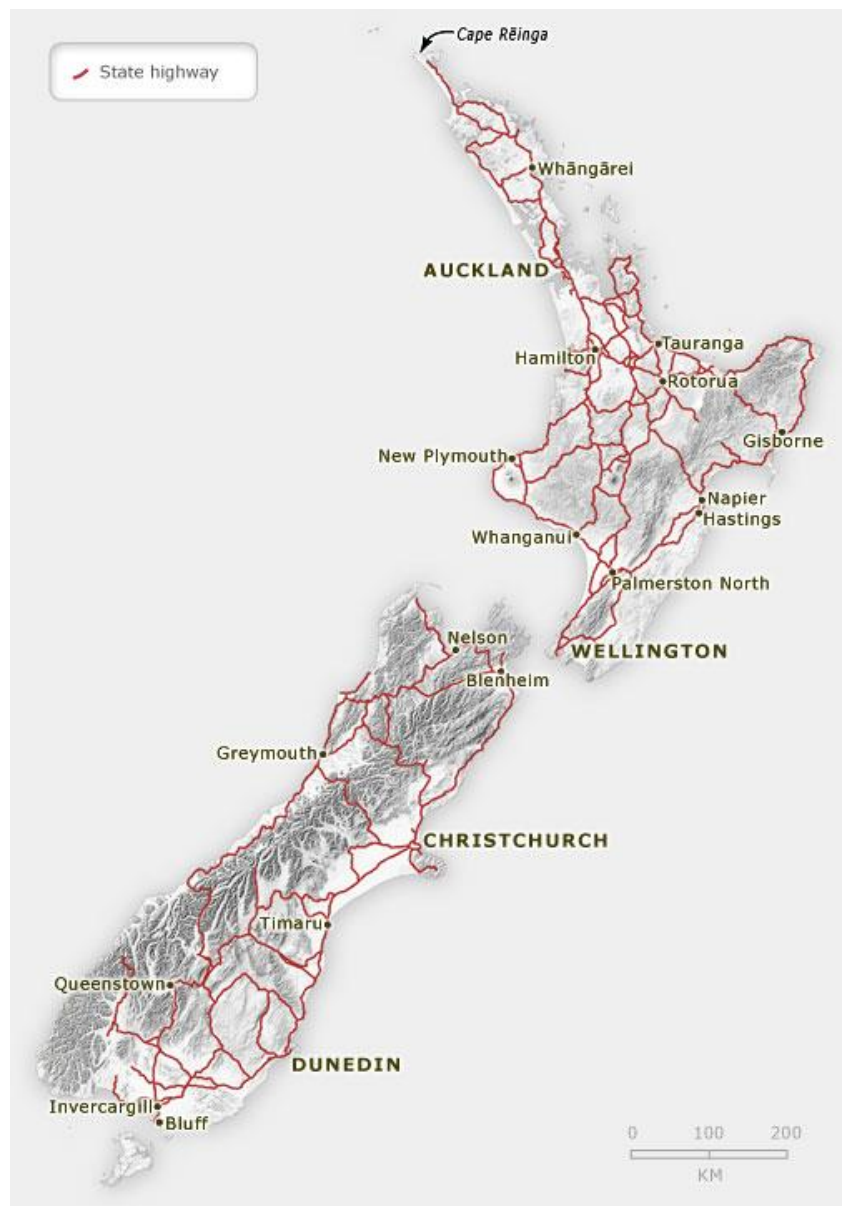

Figure 1.6. New Zealand state highway network. From Te Ara Online Encyclopedia (2016) 


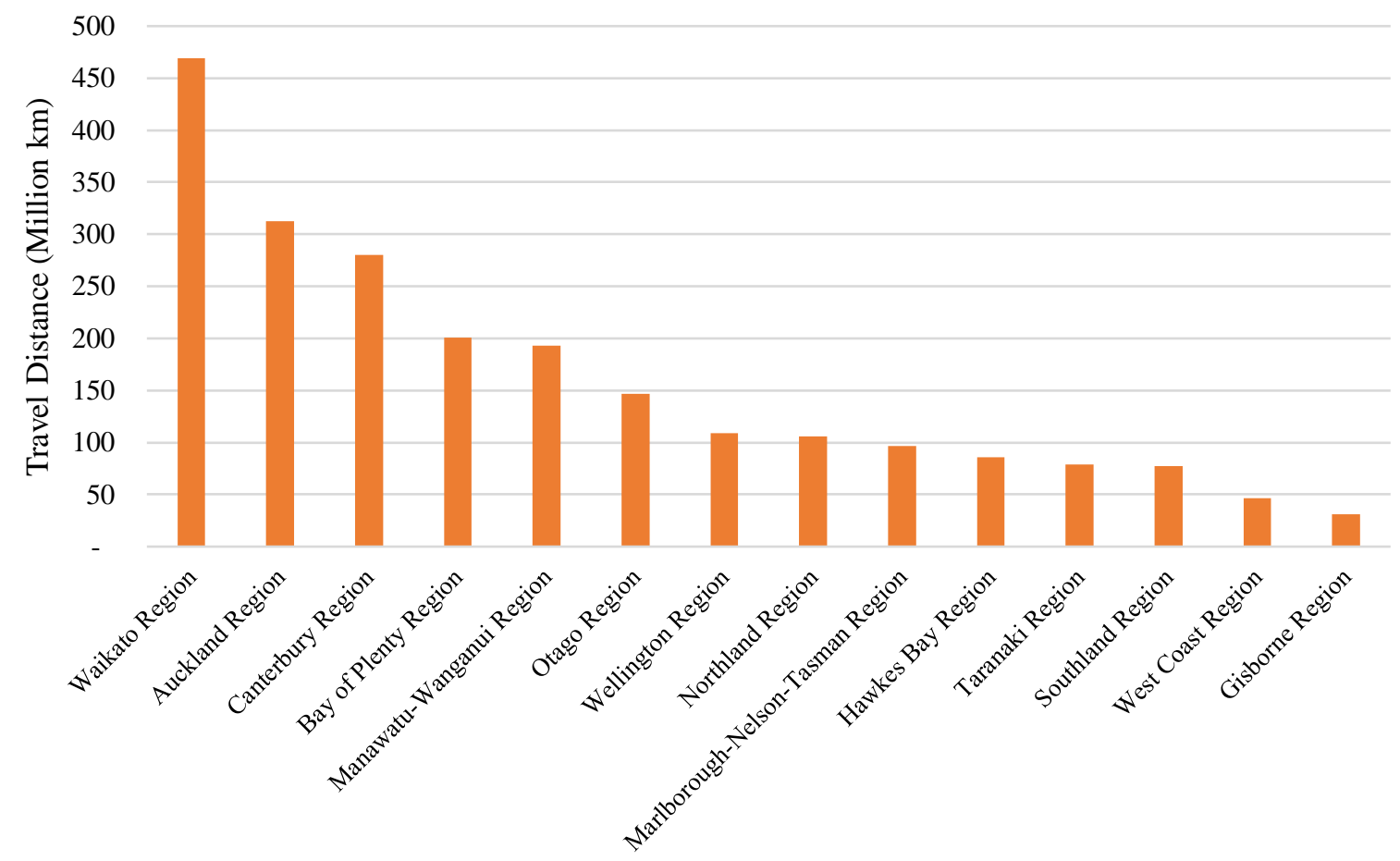

Figure 1.7. Regional heavy vehicle TKM on state highways in 2017. From NZTA (2018)

\subsubsection{Economic relevance of heavy vehicles}

Heavy vehicles, especially the very heavy ones (VHVs), are the main transport mode for road freight. In the case of New Zealand, road freight activities are indicators of economic activity. Gross domestic product (GDP) is a general measure of the economic activity of a country in terms of the value of domestically produced goods and services. Production and transfer of goods from point to point is a two-pronged affair. As such, exploring the relationship of economic measure and road freight is important. A discussion of road freight activity and its significance to New Zealand's economy presents an opportunity for green hydrogen fuel. Since economic activity is dependent on road freight, decarbonizing the freight sector should not negatively affect domestic economic activities.

Road transport represents about $90 \%$ of freight tons and $70 \%$ of freight ton-kilometres of overall freight modes in New Zealand (NZFS, 2014). Both ton and ton-kilometres are parameters that can describe freight activities in a country. Traffic volume is a significant measure of economic performance and momentum (ANZ, 2019). The heavy traffic index has a striking correlation to real GDP (Figure 1.8). ANZ uses the heavy traffic index in its Truckometer survey. The growth of GDP and TKM illustrates a similar pattern (Figure 1.9). These are good indications of how freight activities indicate GDP trends in New Zealand. 


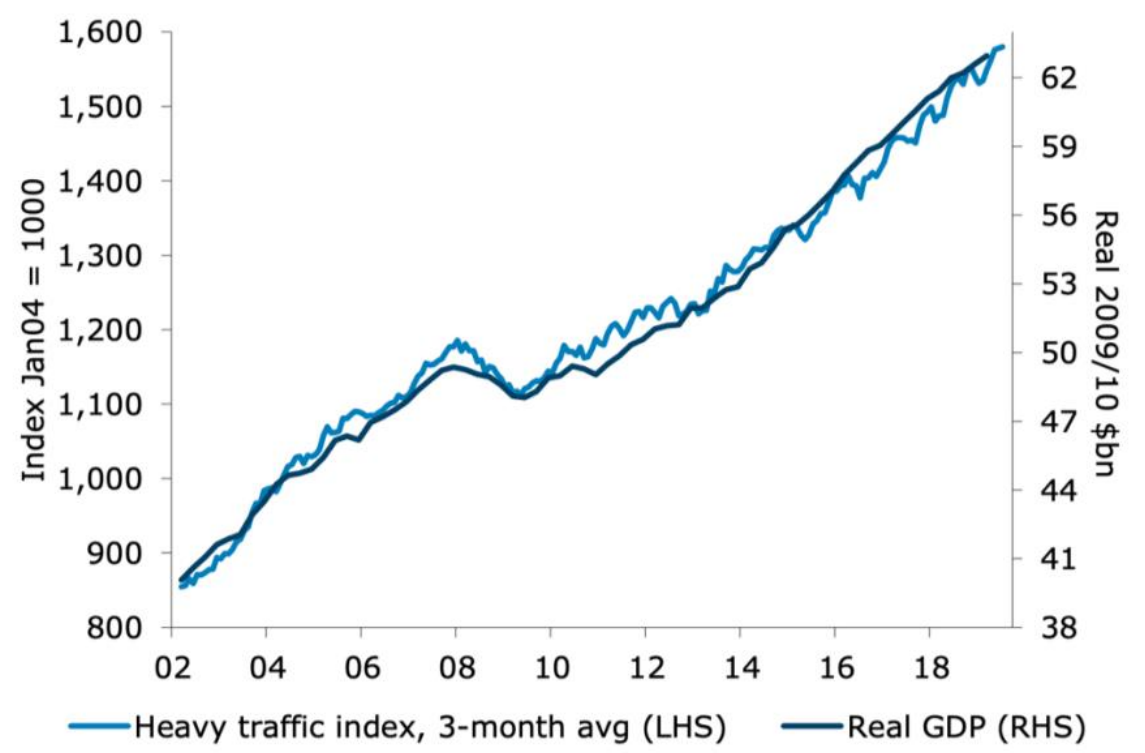

Figure 1.8. Heavy traffic index and GDP. From ANZ (2019, p.1)

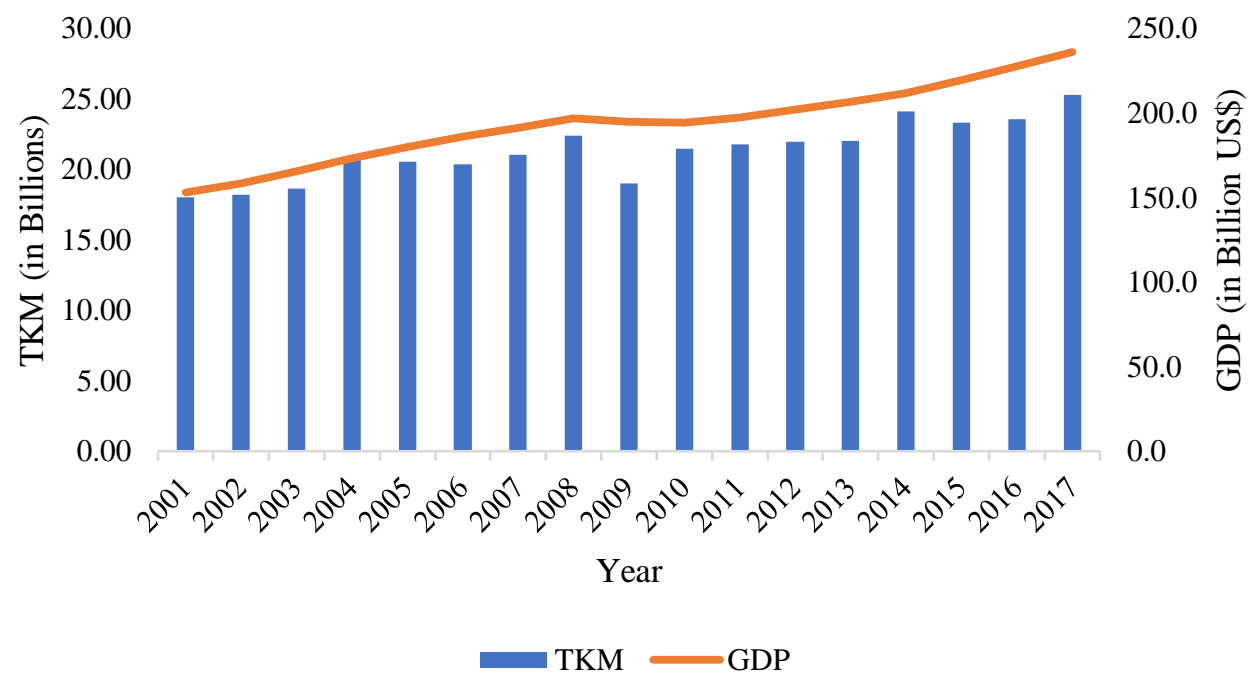

Figure 1.9. Comparison of GDP and TKM growth from 2001 to 2017. From NZTA (2018)

Heavy vehicles are primarily used for domestic road freight, transferring goods from their point of production or import to their point of use or export. Goods may sometimes pass through intermediate processing facilities before reaching their final destination for both domestic use and export (Deloitte, 2018). The Ports of Auckland, Tauranga (Bay of Plenty) and Lyttleton in Christchurch (Canterbury) are the main ports in New Zealand. Some commodities produced in New Zealand are dairy, forestry, agricultural products, coal, petroleum, cement, manufactured and retail goods (NFDS-MOT, 2014). In essence, vehicles transferring goods use the state highways (Figure 1.6) to move within and between regions. Each region has its own "specialty" when it comes to production. This is evident in the million tons (Mt) of generated freight in each region, from the New Zealand Freight Demand Study (Ministry of Transport, 
2014). For instance, forestry is a specialty of Northland (4.35 MT), Waikato (5.15 MT) and Bay of Plenty $(9.80 \mathrm{MT})$. These regions are relatively large in land area and are also endowed with favourable climatic conditions for the growth of trees for wood production. Dairy is a specialty of Waikato (7.08 MT) with $34 \%$ of herds and $27 \%$ of milk produced in New Zealand. Agriculture is a key industry in Canterbury (3.97 MT) which has the most irrigated land by region in the country, while the Bay of Plenty (2.72 MT) is the largest producer of avocado and kiwifruit in the country. Auckland is the largest source of manufactured (9.91 MT) and retail goods (11.77 MT). Overall, Auckland and Canterbury are the two most freight-intensive regions in New Zealand (Deloitte, 2017; Ministry of Transport, 2014). This is not surprising, as these are also the most populated regions. Population is a big contributor in the overall road freight activity (Deloitte, 2017). In 2014, both ton and TKM measures are indicative of the population across regions (Figure 1.10). This is noticeable for Auckland and Canterbury. 


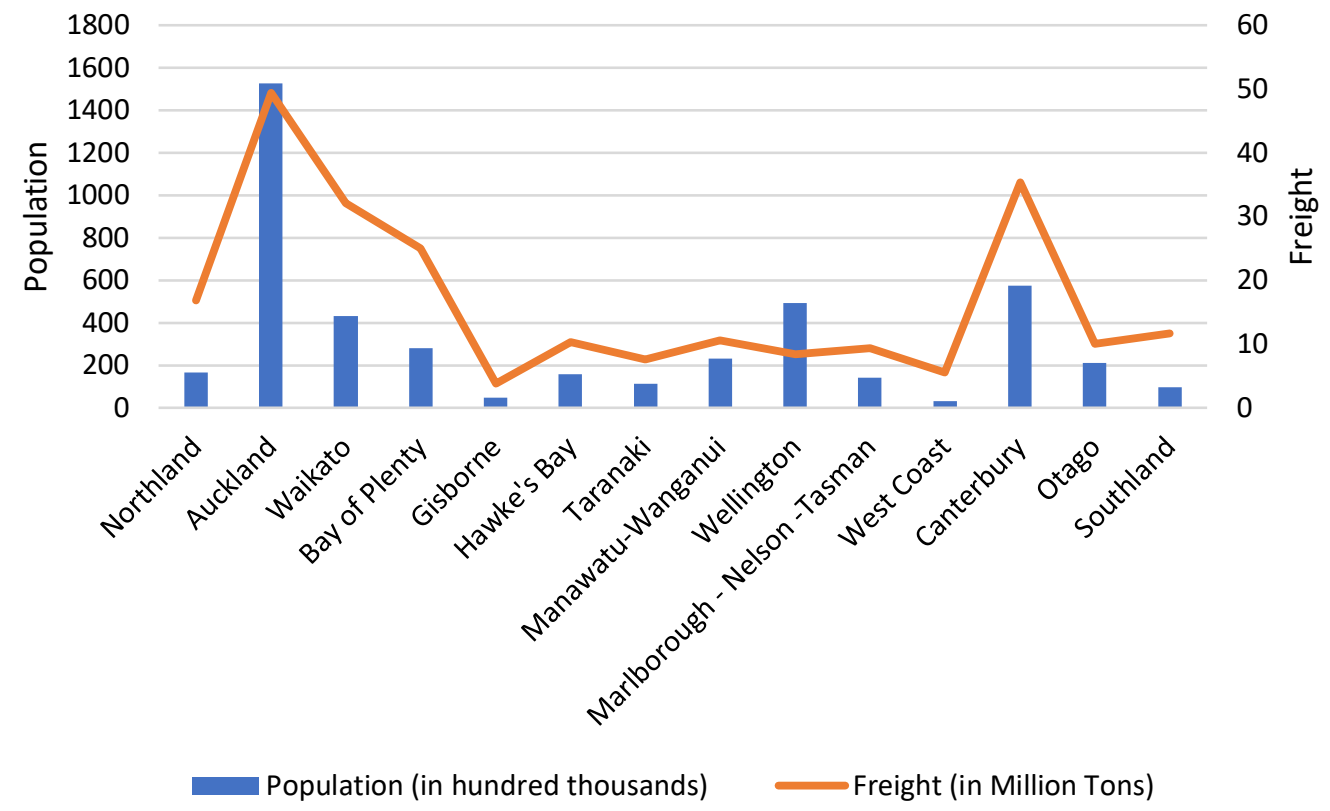

(a)

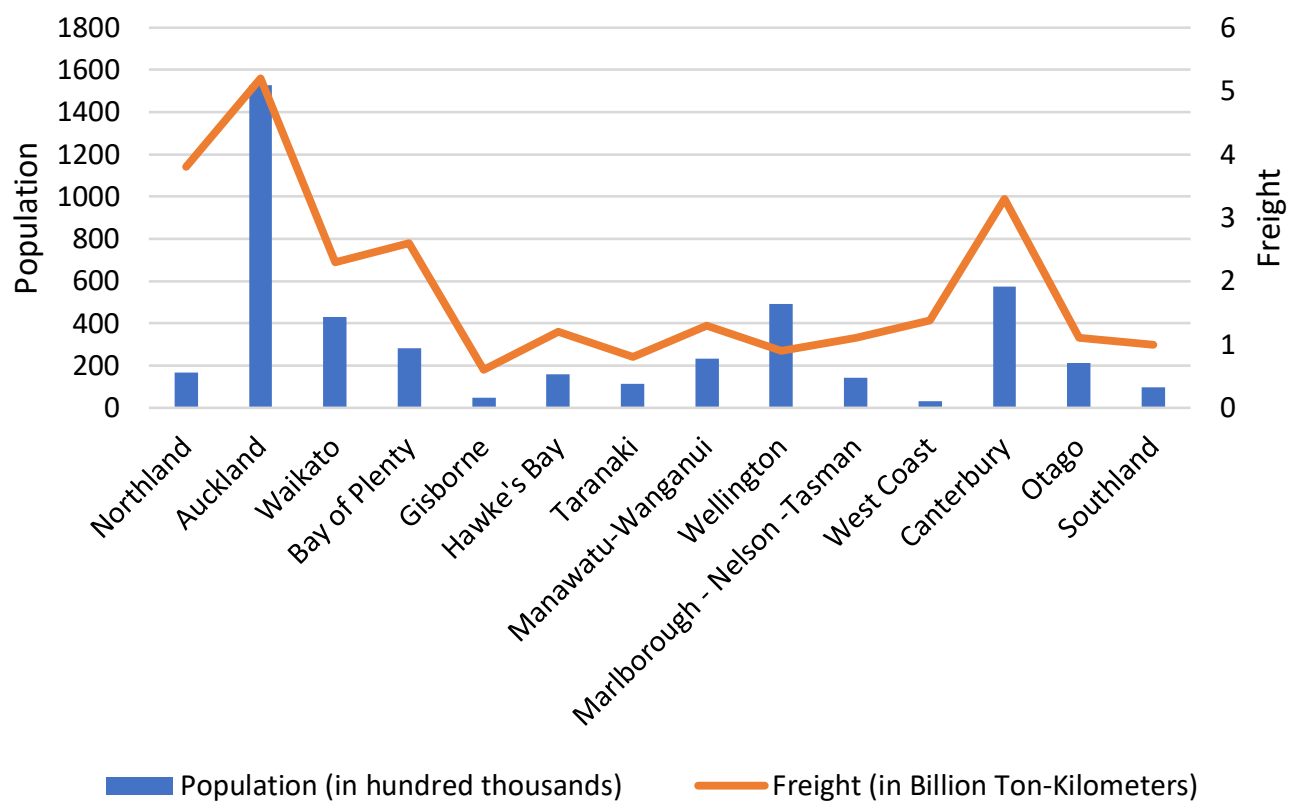

(b)

Figure 1.10. Comparison of population and road freight in tons (a) and ton-kilometres (b) in 2014. From Stats NZ (2019) and Deloitte (2018)

\subsubsection{New Zealand hydrogen vision}

In September 2019, the Ministry of Business, Innovation and Employment (MBIE) released a green paper on the hydrogen vision of New Zealand. It aims to determine the potential of 
green hydrogen on a national scale in the sectors of energy, transport, and hydrogen exports. The green paper is a product of consultation of opportunities and challenges for hydrogen from multiple stakeholders.

On a global scale, there is momentum for technology transformation and decarbonization initiatives. Trends in research and development, carbon financing infrastructure, and the development of a global hydrogen market are some of the things that New Zealand can learn from the international community. An excerpt of government success and initiatives for the uptake of fuel cell vehicles is shown in Table 1.1. On a national scale, the New Zealand government aims to be more productive, more sustainable and more inclusive. The aims include (aspirational) targets for 100\% renewable energy by 2035 and a net zero carbon economy by 2050. Whilst moving towards a sustainable economy, prosperity is also within reach as hydrogen can generate jobs. The additional workforce for the hydrogen industry complements the already successful workforce in the renewable energy sector. 
Table 1. 1. Global development in fuel cell vehicles. From IEA Hydrogen (2017) and Hydrogen Council (2017)

\begin{tabular}{|c|c|}
\hline Country & Fuel Cell Developments \\
\hline Japan & $\begin{array}{l}\text { Government milestone targets: } \\
2017-3,000 \\
2020-40,000 \text { (including buses) } \\
2025-200,000 \\
2040-800,000\end{array}$ \\
\hline California & 1600 registrations in 2017, increase of 1300 from 2016 \\
\hline Norway & Incentivizes FCEVs \\
\hline UK & 49 FCEVs registered \\
\hline Denmark & 75 FCEVs registered \\
\hline China & $\begin{array}{l}\text { Investment of } \$ 17 \text { Million for } 300 \text { fuel cell buses; } \\
1500 \text { hydrogen buses for public transport }\end{array}$ \\
\hline South Korea & Replace 26,000 CNG buses with fuel cell buses by 2030 \\
\hline Europe & $\begin{array}{l}\text { Funding to deploy } 139 \text { fuel cell buses; } \\
\text { Deployment of } 600 \text { to } 1000 \text { hydrogen buses by } 2020\end{array}$ \\
\hline UK & Targeted 42 buses in 2017 \\
\hline
\end{tabular}

The hydrogen opportunity in New Zealand can be divided into sector applications, such as transport, agriculture and industrial, commercial, and residential applications. For transport, there is a pressing need to decarbonize, as $40 \%$ of fossil fuels consumed and $18 \%$ of emissions in New Zealand are from this sector. In terms of fleet decarbonization, light vehicles are better served by direct electrification, while heavy duty vehicles are more appropriate for the hydrogen option (Concept Consultancy, 2019). In this case, battery and fuel cell electric options are complementary, not competing solutions (Figure 1.11). For agriculture, hydrogen can be used as feedstock for fertilizer production (e.g. ammonia). It can also be utilised for power and heating in the process chain and can provide hydrogen mobility for the supply and distribution chain. For industrial, commercial and residential applications, there is an opportunity for hydrogen energy transformation in process, space and water heating. Hydrogen can be produced, stored and converted through various processes using different chemical feedstocks. These options can be tailor-made for each end-use application. In terms of safety, hydrogen is generally safe, and the level of safety can also be customized to each end-use application as with other fuels. In terms of distribution, the existing gas network can 
potentially be repurposed for domestic hydrogen distribution ${ }^{1}$. New Zealand also has opportunity for international export of hydrogen to countries such as Japan and South Korea. But there are technological and economic challenges in terms of transport and distribution, as hydrogen has low weight and energy density. Transcending all applications, the high renewable energy levels in New Zealand present one of the largest opportunities for green hydrogen. This is complemented with New Zealand's resilient existing grid. With an $85 \%$ renewable energy share as of 2018, New Zealand has the fourth largest renewable energy levels in the OECD countries. Realizing the potential of green hydrogen requires sufficient renewable energy supply (MBIE, 2019b).

PASSENGER VEHICLES

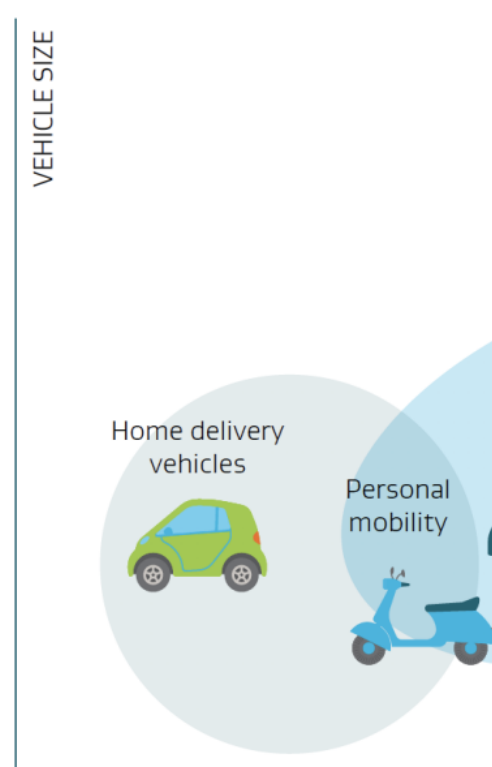

PUBLIC TRANSPORT, FRIEGHT, MATERIALS HANDLING

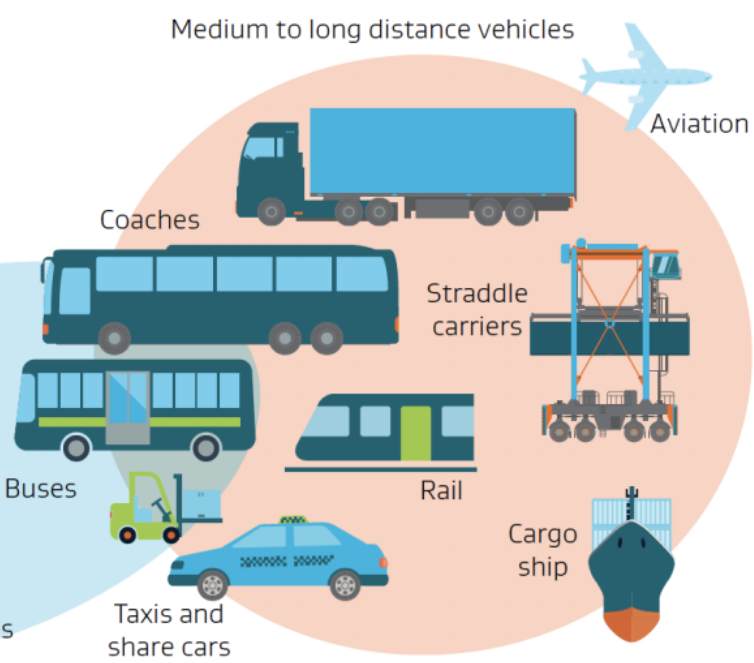

TRAVEL DISTANCE
Fuel
Battery
Gasoline, diesel, biofuels, CNG, synthetic fuels etc
Hydrogen

Figure 1.11. Complementary roles of battery electric and hydrogen fuel in the transport fleet decarbonization. From MBIE (2019, p. 50)

\subsection{Thesis structure}

Chapter 2 presents the literature review of the study and outlines the important considerations and parameters for the techno-economic analysis of green hydrogen fuel.

Chapter 3 discusses the research approach to answer each research question. This chapter also outlines the calculations and estimation methods, as well as the initial results obtained from the calculations.

\footnotetext{
${ }^{1}$ https://firstgas.co.nz/news/hydrogen-pipeline-project-gets-government-funding/
} 
Chapter 4 provides a discussion of the results for each research question. This includes sizing of hydrogen demand, availability of renewable energy supply, and hydrogen cost scenarios.

Chapter 5 provides the summary, conclusions, and recommendations of the study. 


\section{Chapter 2 - Literature review}

This chapter discusses the techno-economic assumptions that shape the green hydrogen fuel analysis. It aims to justify these assumptions and provide a basis for the techno-economic analysis. In particular, the chapter focusses on each theme of the research question, namely: hydrogen demand, hydrogen from renewable energy, and levelized hydrogen cost.

\subsection{Hydrogen demand}

The first step in the green hydrogen fuel analysis is the sizing of the hydrogen demand for very heavy vehicles (VHVs). This study assumes that the overall hydrogen demand for VHVs is proportional to its aggregate diesel consumption. In order to support this assumption, electrolysers, hydrogen for transport, and diesel consumption are discussed.

\subsubsection{Hydrogen from electrolysis}

The history of hydrogen production can be traced back to the 1800 s when scientists William Nicholson and Anthony Carlisle discovered the process of electrolysis: the splitting of water molecules into hydrogen and oxygen. Consequently, electrochemistry was also founded (Siemens, 2018). Electrolysis was, for a time, a standard for hydrogen production but it cannot (economically) produce large amounts of hydrogen for industrial purposes because of technology constraints. Gas reforming and coal gasification, which are thermochemical processes that release $\mathrm{CO}_{2}$ as a by-product from burning fossil fuel, have dominated largescale hydrogen production. Fossil based hydrogen supplies about $95 \%$ of worldwide hydrogen demand (Lettenmeier, 2019; Siemens, 2018). In order to achieve carbon-free large-scale hydrogen production, electrolysis supplied by renewable electricity must be harnessed. The process of electrolysis is shown in Figure 2.1.

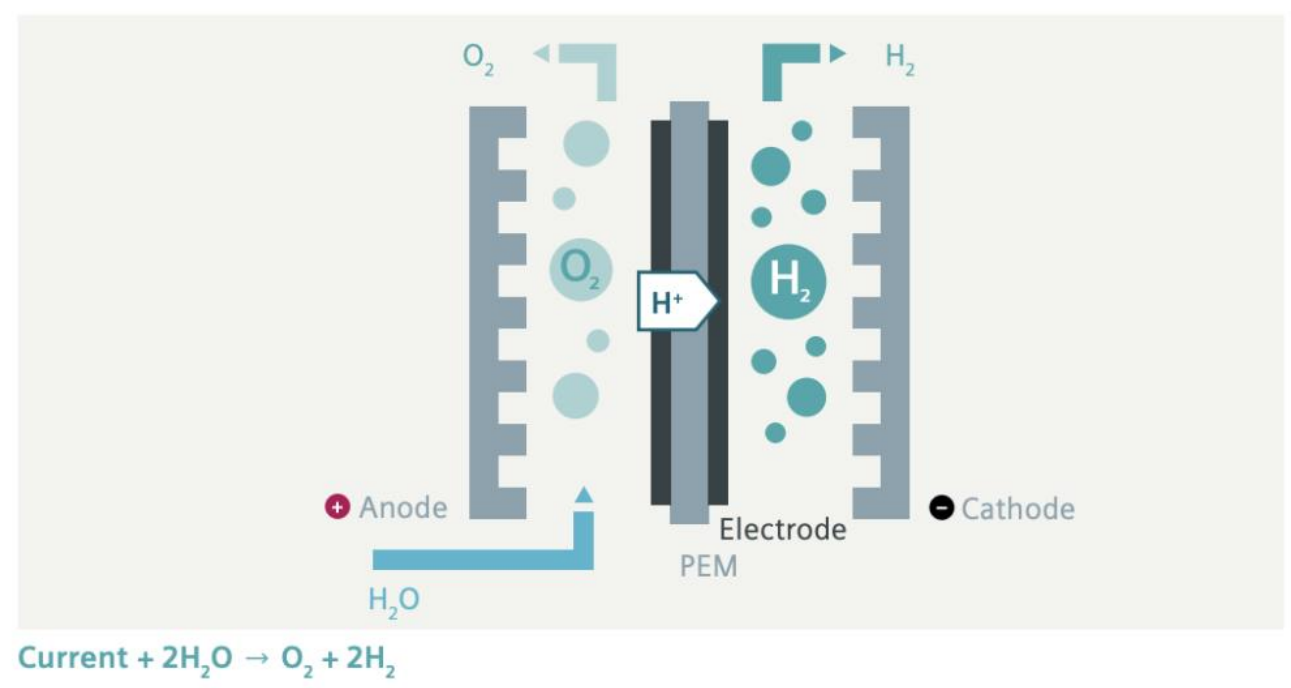

Figure 2.1. Basic diagram for electrolysis. From Siemens (2018, p. 3) 
Electrolysis systems have three operational parameters: water consumption, power consumption and efficiency. Water consumption usually ranges from $8.8-223 \mathrm{~m}^{3} / \mathrm{kg}$ of hydrogen (Mehmeti, Angelis-Dimakis, Arampatzis, McPhail, \& Ulgiati, 2018). In terms of overall consumption, fossil-based hydrogen production has higher water footprint compared to RE-based production (Shi, Liao, \& Li, 2020). Electrolytic power consumption is a function of hydrogen flow rate, which ranges from $4.53-7.3 \mathrm{KWh} / \mathrm{Nm}^{3}$ of hydrogen (Pascuzzi, Anifantis, Blanco, \& Mugnozza, 2016). Electrolyser efficiency is usually $70-75 \%$ for alkaline electrolysers and about $80-85 \%$ for PEM electrolysers and is a function of current density and temperature (Dell, Moseley, \& Rand, 2014; Pascuzzi et al., 2016). Higher current density is needed to produce larger amounts of hydrogen from a given electrolyser area. Operating temperature must also be optimised because higher temperatures are a consequence of larger amounts of hydrogen production, and system aging increases as operating temperature increases. (Lettenmeier, 2019).

Electrolyser systems can be classified into three types, namely: alkaline, polymer electrolyte membrane (PEM), and solid oxide electrolyser cell (SOEC). Table 2.1 summarizes each electrolyzer's characteristics.

Table 2.1. Electrolyser characteristics. From Manage, Hodgson, Milligan, Simons, and Brett (2011)

\begin{tabular}{|c|c|c|c|}
\hline & Alkaline & PEM & SOEC \\
\hline $\begin{array}{l}\text { Operating } \\
\text { Temperature }\left({ }^{\circ} \mathrm{C}\right)\end{array}$ & $70-90$ & $<100$ & $500-1000$ \\
\hline $\begin{array}{l}\text { Electrolyte: Ion } \\
\text { Material }\end{array}$ & $\mathrm{KOH}_{(\mathrm{aq})}, \mathrm{NaOH}_{(\mathrm{aq})}$ & Sulfonated polymers & $\begin{array}{l}\mathrm{O}^{2-} \\
\text { Yttria stabilized } \\
\text { zirconia } \quad \text { (YSZ), } \\
\text { Scandia-stabilized } \\
\text { zirconia }\end{array}$ \\
\hline $\begin{array}{l}\text { Cathode: } \\
\text { Reaction } \\
\text { Material }\end{array}$ & $\begin{array}{l}2 \mathrm{H}_{2} \mathrm{O}+2 \mathrm{e}^{-}->\mathrm{H}_{2}+2 \mathrm{OH}^{-} \\
\begin{array}{l}\text { Nickel with platinum } \\
\text { catalytic coating }\end{array}\end{array}$ & $\begin{array}{ll}2 \mathrm{H}^{+}+2 \mathrm{e}^{-}->\mathrm{H}_{2} & \\
& \\
\text { Platinum } & \text { black, } \\
\text { iridium oxide } & \left(\mathrm{IrO}_{2}\right), \\
\text { ruthenium } & \text { oxide } \\
\left(\mathrm{RuO}_{2}\right) & \\
\end{array}$ & $\begin{array}{l}\mathrm{H}_{2} \mathrm{O}+2 \mathrm{e}^{-}->\mathrm{H}_{2}+\mathrm{O}^{2-} \\
\text { Nickel-YSZ cermet }\end{array}$ \\
\hline Anode: Reaction & $\begin{array}{l}2 \mathrm{OH}^{-} \rightarrow 1 / 2 \mathrm{O}_{2}+\mathrm{H}_{2} \mathrm{O}+ \\
2 \mathrm{e}^{-} \\
\text {Nickel or copper coated } \\
\text { with metal oxides }\end{array}$ & 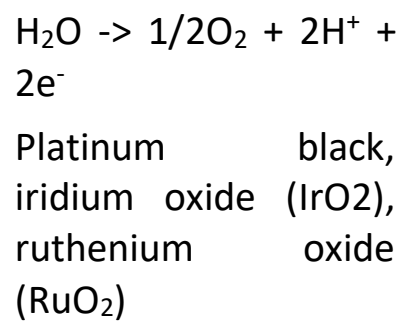 & $\begin{array}{l}\mathrm{O}^{2-}-1 / 2 \mathrm{O}_{2}+2 \mathrm{e}^{-} \\
\text {Perovskite oxides (e.g. } \\
\text { lanthanum } \\
\text { manganate) }\end{array}$ \\
\hline
\end{tabular}

Alkaline electrolysers are described as the earliest, most common, and most leveraged in terms of market and commercialization among the types of electrolysers (M. S. Genç, Çelik, \& Karasu, 2012; Manage, et al., 2011; Mohammadi \& Mehrpooya, 2018; Olateju, Kumar, \& 
Secanell, 2016). They are appropriate for large-scale operation because of their efficient operation at lower current densities (Lettenmeier, 2019) and market maturity (Parra, Valverde, Pino, \& Patel, 2019). However, operation under intermittent electricity provision is undesirable as intermittent electricity supply can reduce system lifetime and increase the cost of maintenance (Manage et al., 2011; Mansilla, Louyrette, Albou, Bourasseau, \& Dautremont, 2013; Mohammadi \& Mehrpooya, 2018). Alkaline electrolysers use an aqueous electrolyte solution with a porous membrane to allow hydrogen and oxygen molecules to pass through. This setup is prone to hazardous mixing of the two gases. Another reported issue with alkaline electrolysers is the potential for additional losses from shunt currents at high current densities, resulting in increased operating temperature and reduced efficiency (Lettenmeier, 2019; Yodwong et al., 2020). This is solved by a polymer electrolyte separator in PEM electrolysers (Figure 2.2).

PEM electrolysers are the second most commercialized electrolyser. PEM electrolysers have the ability to withstand operation under intermittent electricity (G. Genç, Çelik, \& Serdar Genç, 2012; Loisel, Baranger, Chemouri, Spinu, \& Pardo, 2015; Manage et al., 2011; Menanteau, Quéméré, Le Duigou, \& Le Bastard, 2011; Mohammadi \& Mehrpooya, 2018). Another advantage is that they can operate at higher pressures, enabled by the electrolyte's polymeric nature (Lettenmeier, 2019). A disadvantage is the reliance on specific and rare materials that can be expensive such as platinum and iridium (Mohammadi \& Mehrpooya, 2018). Two electrolyser manufacturers, Hydrogenics and Siemens, have announced the technical specification of their PEM electrolysers (Table 2.2). They claim that PEM electrolysers have taken advantage of relevant technological improvements from alkaline electrolysers (Hydrogenics, 2018; Siemens AG, 2017).
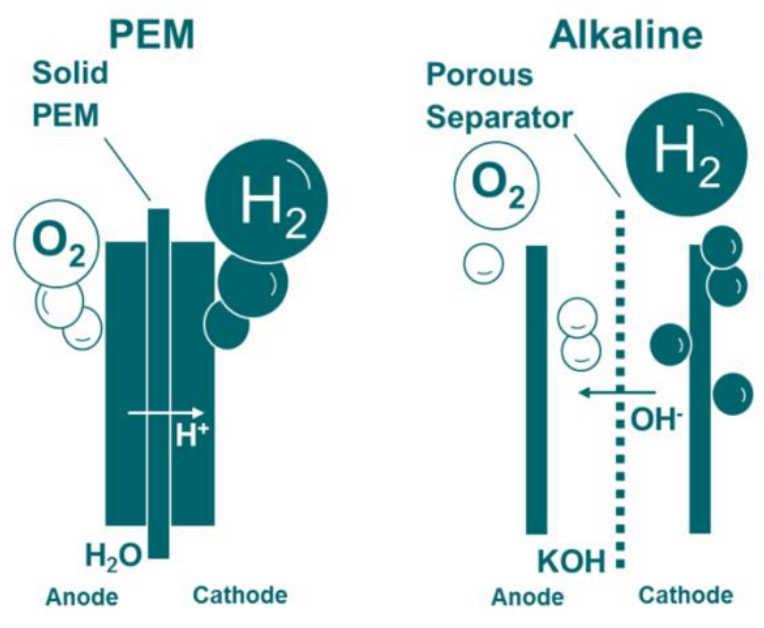

Figure 2.2. Alkaline and PEM electrolysers. From Lettenmeier (2019, p. 5) 
Table 2.2. Technical specifications for PEM electrolysers

\begin{tabular}{|l|l|l|}
\hline Parameter & HyLYZER $^{\text {TM }}$ (Hydrogenics) & SiLYZER $^{\text {TM }}$ (Siemens) \\
\hline Output pressure & $30 \mathrm{bar}$ & $35 \mathrm{bar}$ \\
\hline Input power & $5 \mathrm{MW}$ & $1.25 \mathrm{MW}$ (stack) \\
\hline Nominal flow & $1,000 \mathrm{Nm}^{3} / \mathrm{h}$ & $225 \mathrm{Nm}^{3} / \mathrm{h}$ \\
\hline AC consumption & $59.9 \mathrm{kWh} / \mathrm{kg}$ & $62 \mathrm{kWh} / \mathrm{kg}$ \\
\hline
\end{tabular}

SOECs are the newest types of electrolysers. This technology has the highest efficiency among the electrolyser types and can be competitive with steam methane reforming (SMR). It is, however, disadvantaged because of its market infancy (Mohammadi \& Mehrpooya, 2018).

In Europe, 35 hydrogen fuel projects were implemented from 2003 to 2018 . Nineteen use alkaline electrolysers, 13 PEM and 3 SOEC electrolysers. However, most of the alkaline electrolyser projects have exceeded their lifetime and have already been decommissioned. These projects have technology readiness levels between six and seven, which suggests that these projects are small yet operational in relevant environments (Wulf, Linßen, \& Zapp, 2018).

The selection of electrolyser type was based on costing, efficiency, and commercial readiness. Considering technical advantages, the PEM electrolyser is the assumed electrolyser in this study as it can withstand intermittent operation. Also, the PEM electrolyser is expected to see the most growth in global electrolytic hydrogen production (IEA, 2019; Schmidt et al., 2017).

\subsubsection{Hydrogen for transport}

Based on end-use applications, hydrogen produced from electrolysis can be prescribed for purposes such as for vehicle fuel and energy storage. As discussed above, fossil fuels currently dominate as a transport energy source, providing an opportunity for hydrogen to replace fossil fuels as a transport fuel (Linnemann \& Steinberger-Wilckens, 2007; Menanteau et al., 2011; Olateju et al., 2016; Rahimi, Meratizaman, Monadizadeh, \& Amidpour, 2014).

Hydrogen can tackle sectors which are "battery challenged", such as heavy-duty transport, non-electrified rail, and maritime transportation. While possible, electrified transport may not always meet performance standards and the criterion of charging convenience (Hydrogen Council, 2017). Moreover, hydrogen-powered vehicles, or fuel cell electric vehicles (FCEVs), have the following particular advantages over internal combustion vehicles and battery electric vehicles (BEVs):

- FCEVs can drive longer (more than $500 \mathrm{~km}$ ) without frequent refuelling.

- Refuelling times for FCEVs are similar to gasoline and diesel vehicles.

- Hydrogen fuel has higher energy densities compared to stored energy in battery vehicles. Because of this, the sensitivity of FCEV powertrain cost and weight to the

${ }^{2}$ Conversion of $11.1 \mathrm{Nm}^{3} / \mathrm{kg}$. From IRENA (2018a). 
amount of energy stored (in kWh) is low. This is particularly beneficial for vehicles that require larger energy storage, such as heavy vehicles used for heavy load capacity and long ranges.

- Infrastructure for FCEVs resembles that of gasoline fuel infrastructure, which adds value to practicality, and capital costs.

All land vehicle types are potential niche markets for hydrogen fuel, but medium to heavy vehicles can truly benefit from longer ranges and fewer refuelling stops (Hydrogen Council, 2017). Compared to battery electric vehicles, however, fuel cell vehicles are relatively new to the market. At present, large battery electric vehicles and fuel cell technologies are still expensive relative to small battery electric vehicles. Without significant improvements in battery technology, hydrogen becomes the only viable low-carbon electrification option for medium to heavy trucks. Fuel cell technology will become cost competitive with battery technology by 2025 for medium to heavy trucks (Hydrogen Council, 2020). In the case of longrange heavy-duty transport, hydrogen may be the only realistic alternative (Hydrogen Council, 2020). Successful programs for hydrogen vehicles include the following:

- A heavy duty (class 8 ) vehicle was developed by Toyota which can carry $80,000-\mathrm{lb}$ loads and can travel up to 200 miles per refuelling; and

- Nikola motors also presented a class 8 vehicle for mass production in 2020.

- A food distributor in Norway adopted 4 trucks and 10 forklifts, and a retailer in Switzerland is operating a 100kW PEM fuel cell truck with a 38-ton capacity and 375kilometer range (IEA Hydrogen, 2017).

- There have also been successful runs of hydrogen light rail vehicles in Canada (2002) and Japan (2006). Hydrogen trains are useful in replacing diesel powered trains, especially on un-electrified rails in the countryside such as was the case in Germany in 2017. In terms of investment confidence in hydrogen-powered trains, Hydrogenics signed a 10 -year $€ 50$ million agreement to supply fuel cell systems to commuter rails in Europe (IEA Hydrogen, 2017). ESORO and Hyundai have recently announced that their hydrogen trucks are ready for fleet commercialization. Technical specifications for the two trucks are compared in Table 2.3.

Table 2.3. Technical specifications of the hydrogen trucks. From ESORO (2017) and Hyundai Motors New Zealand (2019)

\begin{tabular}{|l|l|l|}
\hline Parameters & Hyundai fuel cell truck & ESORO fuel cell truck \\
\hline Gross vehicle weight & $34 \mathrm{t}$ & $34 \mathrm{t}$ \\
\hline Driving range & approx. $400 \mathrm{~km}$ & $375-400 \mathrm{~km}$ \\
\hline Hydrogen consumption & $8.2 \mathrm{~kg} / 100 \mathrm{~km}$ & $7.5-8.0 \mathrm{~kg} / 100 \mathrm{~km}$ \\
\hline Tank capacity & $32.86 \mathrm{~kg} \mathrm{H}$ & $34.5 \mathrm{~kg} \mathrm{H}$ \\
\hline Tank pressure & $350 \mathrm{bar}$ & $350 \mathrm{bar}$ \\
\hline
\end{tabular}




\subsubsection{Hydrogen and diesel trucks}

At present, diesel and petrol are the dominant fuel source for road transport in New Zealand in respect of fuel economy and vehicle numbers (Concept Consultancy, 2019; MBIE, 2018). While no silver bullet for all applications, hydrogen excels in some respects. There is a general recognition that trucks are potentially the "low-hanging fruit" for hydrogen fuel (Concept Consultancy, 2019; Hydrogen Council, 2020; MBIE, 2019b). For instance, the fuel economy for heavy-duty diesel trucks is about $43 \mathrm{l} / 100 \mathrm{~km}$ (Collier et al., 2019) and $8 \mathrm{~kg} / 100 \mathrm{~km}$ for hydrogen trucks (ESORO, 2017; Hyundai Motors New Zealand, 2019). Alternatively, a diesel truck runs at about $2.77 \mathrm{~km} / \mathrm{kg}$ and a hydrogen truck at $12.5 \mathrm{~km} / \mathrm{kg}$. It can therefore be observed that hydrogen in a fuel cell truck has more mileage than petrol or diesel in an internal combustion diesel truck (Lee, Elgowainy, Kotz, Vijayagopal, \& Marcinkoski, 2018).

In terms of efficiency, the well-to-tank efficiency of a US Class 6 heavy truck is $83 \%$ for diesel and $42-57 \%$ for fuel cell trucks. As for tank-to-wheel efficiencies, fuel cell trucks can have 50$100 \%$ better efficiencies than diesel trucks. This, however, depends on vehicle operation (including speed) and the liquid or gaseous form of the hydrogen fuel (Lee et al., 2018). In terms of price, hydrogen fuel is currently more expensive than diesel fuel. However, diesel prices are highly volatile, depending on international oil market trends. Oil prices are expected to become more volatile as the future of oil production and consumption becomes increasingly uncertain (IEA, 2018). The diesel price in New Zealand in 2019 was around NZ\$ 1.22/I (Ministry of Transport, 2019a), while the hydrogen price is currently estimated to be around NZ\$11.3/kg (Concept Consultancy, 2019). These sample prices indicate a diesel price of around NZ\$ 0.52/ $\mathrm{km}$ and a hydrogen price of around NZ\$0.9/ $\mathrm{km}$. These figures are estimates and real-world data for hydrogen are difficult to obtain and do not include retail margins.

A comparison of truck ownership costs is also challenging as there is no real-world market data for hydrogen fuel cell trucks. From a New Zealand hydrogen case report (Concept Consultancy, 2019), heavy diesel trucks have a unit cost of NZ\$175,000 while an indicative value of a fuel cell truck is NZ\$500,000. With increased production volume for fuel cell trucks in the future, the cost may go down to as low as NZ\$250,000 in 20 years (Concept Consultancy, 2019; Hydrogen Council, 2020). All other maintenance-related costs are similar for both vehicles.

Refuelling is an important part of a truck's productivity. If there is enough onboard fuel, trucks may not need to stop to refuel. Away-from-base refuelling can be convenient with a diesel truck, but less so with a hydrogen truck. This is because hydrogen refuelling stations may be limited compared to diesel refuelling stations, especially in the early roll out stages. The need to refuel away-from-base depends on the full-tank capacity of the truck. For a hydrogen truck with an assumed capacity of $30 \mathrm{~kg}$, a return trip of approximately 400 kilometres in total would not require a refuelling stop, and refuelling happens back at base. Refuelling speeds for both hydrogen and diesel trucks are around 7 minutes (Concept Consultancy, 2019). An advantage of a hydrogen truck is the possibility for onboard storage. The lightweight nature of hydrogen means that storing it onboard will not significantly add to the overall weight of the vehicle. 
Overall, the current situation suggests a relatively expensive well-to-wheel cost of hydrogen. But the technological and operational advantages of hydrogen trucks may help offset the costs. Also, hydrogen costs are expected to reduce in the future.

\subsection{Hydrogen from renewable energy}

The second step in the analysis of green hydrogen fuel is the feasibility of renewable energydriven hydrogen production. This part of the literature discusses why a dedicated RE is considered. Discussion about the RE growth profile and hydrogen production systems is presented.

\subsubsection{Additional RE from consented yet unbuilt projects}

The increasing trend of consented, yet unbuilt, RE capacity is an indication of a strong RE profile in the NZ electricity grid. The trend is attributable to an increase in geothermal and wind capacity, and the retirement of some coal and gas facilities (MBIE, 2018). However, there are challenges in generation variability, especially with wind.

New Zealand has a strong and growing RE share in the electricity generation (as shown in Figure 2.3).

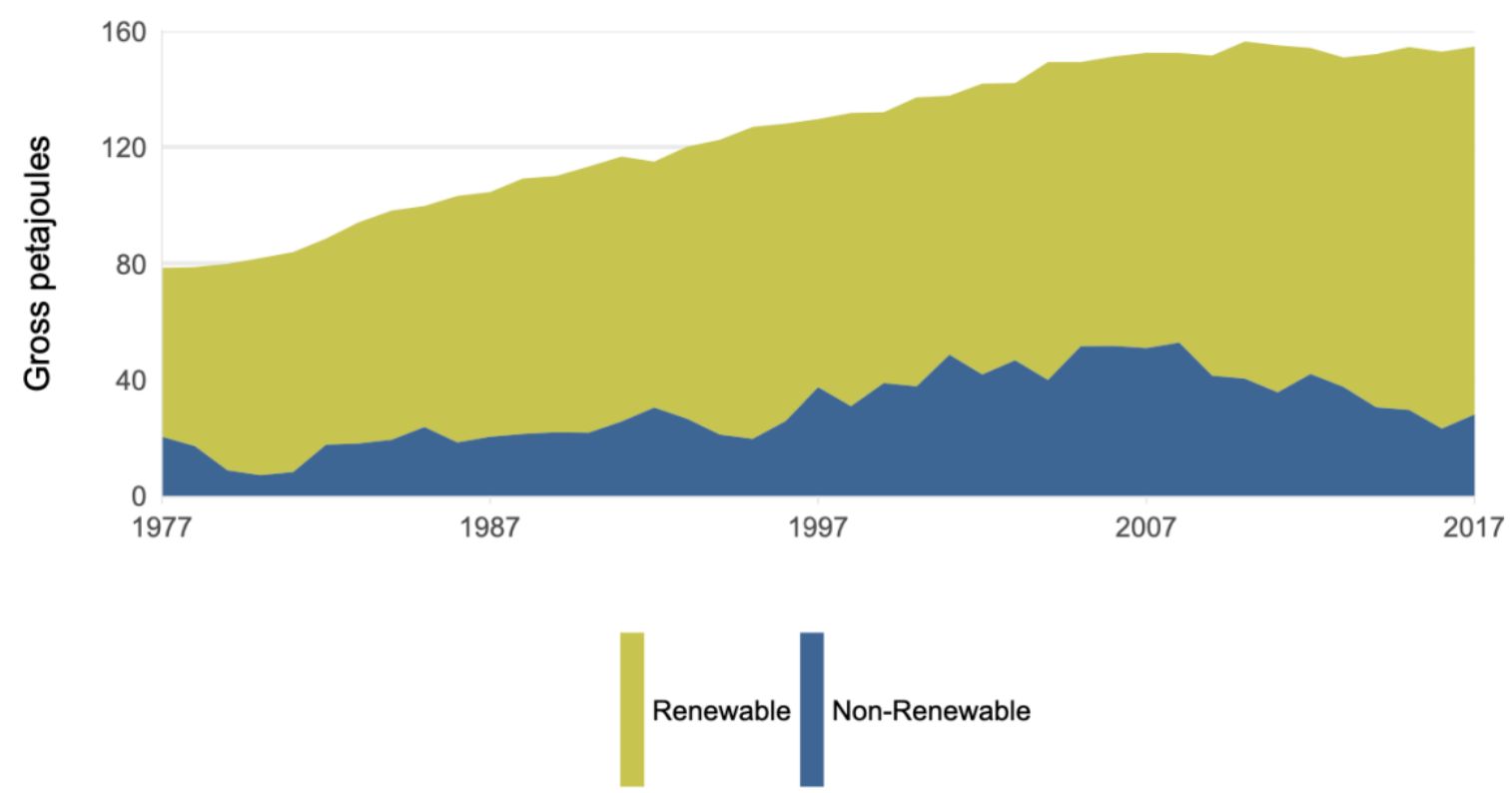

Figure 2.3. Total RE and non-RE electricity generation. From MBIE (2018, p. 54).

A strong and growing RE profile gives a better future case scenario of hydrogen fuel production by purely RE, and vice versa. The New Zealand electricity authority keeps a record of additional consented RE. Wind has the most additional consented generation at 1,800 MW. Of the additional consented RE generating plants, about 1,300 MW are expected to be built in five years' time (MBIE, 2019c). An increase of $R E$ generation can be driven by transformation in the transport sector and an increase in demand for electricity throughout 
the economy. This case can bring RE up to $45 \%$ in a "kayak scenario" ${ }^{3}$ and $55 \%$ in a "waka scenario" 4 (BusinessNZ Energy Council, 2016). In the waka scenario, strong government support, uptake of electric vehicles, and improvement in the fuel efficiency of heavy vehicles are key drivers in the increase (BusinessNZ Energy Council, 2016). As seen in section 2.1.3, a hydrogen truck has more mileage than a diesel truck for the same weight of fuel. This puts green hydrogen trucks in a position to drive an increase of RE in the total primary energy mix.

\subsubsection{Hydrogen production systems}

A benefit of RE for hydrogen production can be maximized when a case-specific production system is properly selected. Hydrogen production systems can be small- or large-scale, gridconnected or off-grid, centralized or decentralised, with a suitable choice of electrolyser. This discussion justifies the large-scale, grid-connected, decentralised hydrogen production system in the techno-economic analysis.

Green hydrogen systems can operate in small-scale or large-scale applications. Identifying a clear scale of hydrogen production is important as it can affect both the component choices and economic performance of a green hydrogen system (Hydrogen Council, 2020). In largescale green hydrogen applications, additional system features such as hydrogen storage, transportation and distribution are important. Having more and larger system components requires more capital costs. On the other hand, increasing hydrogen produced can lessen the cost per unit of hydrogen. In order to make a profit, maximizing hydrogen production potential from renewable electricity via electrolysis must therefore be in balance with economies of scale. In several studies it can be seen that the basis of creating a large-scale green hydrogen system is the large renewable energy resource that can be tapped to produce hydrogen (Levene, Mann, Margolis, \& Milbrandt, 2007; Linnemann \& Steinberger-Wilckens, 2007; Olateju et al., 2016; Zolezzi, Garay, \& Reveco, 2010). The consideration of large-scale hydrogen production in this study is motivated by two things: first, larger volumes of hydrogen produced can bring down costs; and second, large-scale production can be optimized with a decentralized and grid-connected operation.

A number of proposed green hydrogen systems have opted for a grid connection in order to have a consistent supply of electricity whenever wind generation is not enough and to avoid expensive electricity prices during peak times (Mansilla et al., 2013; Rahil \& Gammon, 2017). Other benefits of a grid-connected system include: ruling out the need for transportation in the case of hydrogen produced on-site (Rahil \& Gammon, 2017), additional capacity for RE generating plants in the case of a hydrogen energy buffer (Gutiérrez-Martín, Confente, \& Guerra, 2010), and more flexible electrolyser configuration and operation (Genç et al., 2012). Some studies have also considered off-grid green hydrogen systems, in which either a dedicated or a hybrid dedicated renewable electricity source is solely powering the electrolytic hydrogen production. An advantage of off-grid systems is that they are able to exploit places with rich renewable energy resources (Levene et al., 2007; Zolezzi et al., 2010). One disadvantage of off-grid systems is that the utilisation factor is limited by the capacity

\footnotetext{
${ }^{3} \mathrm{~A}$ business as usual, market-driven case

${ }^{4}$ Optimistic, government-driven and collaborative efforts
} 
factor of the RE source itself (Concept Consultancy, 2019). Since off-grid hydrogen is produced far from its consumption point, transportation of hydrogen may be necessary, which will add to overall costs for large-scale production (Zolezzi et al., 2010). In this study, a grid-connected system is considered, but an additional feature is that the RE is assumed to be dedicated or embedded for hydrogen production. This can be achieved by connecting the RE plants to the grid, without subjecting them to the wholesale electricity market.

The largest problem concerning green hydrogen systems in general is the intermittency of renewable electricity, thereby resulting in electrolyser power variations and variable hydrogen production (Greiner, KorpÅs, \& Holen, 2007; Mohammadi \& Mehrpooya, 2018). In this study, the RE source is diversified by wind, hydro and geothermal plants. These RE plants have consented status, and as yet are unbuilt. A diversified RE electricity supply is more reliable than a single type of $\mathrm{RE}$ source (MBIE, 2018). Diurnal ${ }^{5}$ hydrogen storage is also assumed in the calculation to allow better flexibility for hydrogen production.

Both small-scale and large-scale systems can be prescribed for decentralized operation. A decentralized electrolyser operation, which consumes dedicated power from renewables, can avoid delivery risks (Bruce et al., 2018; IEA Hydrogen, 2017). Decentralised systems also have greater flexibility in terms of design and scalability by being installed in multiple sites where they can be produced at the point of service, and near to where they can take advantage of a rich renewable electricity source. Location of hydrogen production points is also important from the perspective of heavy truck operators. Production points are more beneficial if placed near heavy vehicles drivers' rest period points (FCHJU, 2017). Electrolysers can also be increased in capacity in a strategic place in order to serve higher transport demand volumes and provide greater flexibility and autonomy for vehicle operators (Bruce et al., 2018). In this study, a decentralized hydrogen production is assumed, so that green hydrogen can be produced at or near its point of use. Decentralized hydrogen production can also be configured in the form of a hydrogen refuelling station (HRS).

The number of HRSs worldwide is on the rise, with a target of more than 3000 hydrogen stations in 2025, sufficient to service about 2 million FCEVs (Hydrogen Council, 2017). Table 2.4 summarizes government targets in HRSs in different countries.

${ }^{5}$ Daily replenishment cycle 
Table 2.4. HRS targets in several countries. From IEA (2017)

\begin{tabular}{|l|l|}
\hline \multicolumn{1}{|c|}{ Country } & \multicolumn{1}{c|}{ HRS Target } \\
\hline Germany & 400 stations by 2023 \\
\hline California & 100 stations by 2020 \\
\hline Japan & 80 operational stations \\
\hline China and South Korea & 830 stations by 2025 \\
\hline
\end{tabular}

The feasibility of HRSs in a country is an important factor that fuel cell vehicle manufacturers consider. The fuel cell vehicle market becomes feasible if HRSs are feasible (Bruce et al., 2018). Establishing the potential for HRSs therefore becomes an important first step for some countries to encourage the uptake of fuel cell vehicles. This study assumes an HRS setup as an initial step for hydrogen production systems in New Zealand. HRSs can be prescribed as a decentralized operation, in which, as demand for green hydrogen fuel increases, electrolysers can be increased in capacity. HRSs can be established in locations within close proximity to the renewable energy resource, on heavy vehicle routes (state highways), and at shipping ports and population centres, thereby eliminating hydrogen distribution costs. The economic viability of scale for large-scale hydrogen production can be determined via the calculation of levelized cost of hydrogen. This study, however, does not specify a design for HRSs, as each HRS can have multiple electrolyser units. Costing for electrolyser capacity on a per KW basis instead of per refuelling station offers simplicity for the calculation of the hydrogen production cost.

\subsection{Hydrogen cost}

The third step in the green hydrogen fuel analysis is the calculation of the cost of hydrogen. Hydrogen cost for transport applications such as trucks, rail, and forklifts are expected to become cost competitive starting early 2020 when conditions are optimised, and will continue towards 2030 under normal conditions (Hydrogen Council, 2020). Assumptions about the use of levelized cost, as well as about hydrogen cost components, are justified here.

\subsubsection{Levelized cost of hydrogen}

Several past studies have also examined the economics of hydrogen production through the concept of levelized cost, borrowing from the concept of levelized cost of energy (LCOE) (Viktorsson, Heinonen, Skulason, \& Unnthorsson, 2017). LCOE determines electricity cost in which the income of selling electricity would balance the cost of generating it. LCOE has been used in past techno-economic studies for incorporating cost analysis including investment costs, component life, escalation ratio and discount rate. Hydrogen output has been expressed in terms of LCOE in both vehicle fuel and energy storage applications (Genç et al., 2012; Genç et al., 2012; Rahimi et al., 2014). LCOE factors include equipment costs, total installed costs, capacity factors, operations and maintenance (O\&M) costs and other components of the weighted average capital cost (WACC) (IRENA, 2018b). LCOE is a functional 
approach in measuring hydrogen, since hydrogen output can also be expressed in terms of energy. Similar to computation of electricity costs, hydrogen costs can therefore be expressed in terms of cost per unit of hydrogen (Viktorsson et al., 2017).

Complementing the LCOE is the Discounted Cash Flow (DCF) analysis, which is used to analyse hydrogen costs by considering investment costs, discount rate, and operations and maintenance expenses. Since it can project future investment outcomes, several hydrogen production scenarios have been drawn up in order to determine the most viable economic path for hydrogen (Levene et al., 2007; Mansilla et al., 2013; Menanteau et al., 2011; Olateju et al., 2016).

In the present study, LCOE will be used to frame the levelized cost of hydrogen (LCOH). DCF analysis will also be used in order to project future hydrogen cost values. The levelized cost approach is simple, allowing greater flexibility in sensitizing important $\mathrm{LCOH}$ parameters such as electricity cost, CAPEX and the utilisation factor (International Renewable Energy Agency (IRENA), 2018). This will be discussed in more detail in the next chapter.

\subsubsection{Hydrogen cost components}

There are three common hydrogen cost components: electricity cost, capital cost, and utilisation rate (Concept Consultancy, 2019; FCHJU, 2017; Hinkley et al., 2016; Thomas, Mertens, Meeus, Van der Laak, \& Francois, 2016). Based on the Hydrogen in New Zealand report, electricity cost comprises $75 \%$ of the total hydrogen per unit cost, while capital cost comprises about $25 \%$. This particular hydrogen cost breakdown assumes large-scale, gridconnected hydrogen production at an $85 \%$ utilisation factor.

\subsubsection{Electricity cost}

Hydrogen cost is directly sensitive to changes in electricity source, regardless of whether electricity is sourced from renewable or non-renewable sources, grid-connected or off-grid (Genç et al., 2012; Greiner et al., 2007; Levene et al., 2007; Linnemann \& SteinbergerWilckens, 2007; Loisel et al., 2015; Manage et al., 2011; Parra et al., 2019; Rahil \& Gammon, 2017). Thus, making predictions on electricity availability and pricing is important in the techno-economic analysis. For instance, considering a variable electricity source in the techno-economic analysis (which is the case for most renewable sources), will affect how green hydrogen systems operate and how volatile hydrogen costs will become (Loisel et al., 2015; Mansilla et al., 2013; Olateju et al., 2016). Fluctuating operation imposes high investment costs, because fluctuating electricity reduces the lifetime of electrolyser equipment (Mansilla et al., 2013). Including fixed electricity in the techno-economic analysis enables the system to consume power whenever available (Rahil \& Gammon, 2017).

Nevertheless, hydrogen produced using renewable electricity is expected to be economically competitive in the future as technology (Mohammadi \& Mehrpooya, 2018) and economies of scale in renewable energy (Zolezzi et al., 2010) improve over time, even when electricity from grids with a high share of renewables will not necessarily offer the cheapest electricity feedstock for grid-connected configurations (Mansilla et al., 2013).

Since this study assumes a dedicated embedded renewable energy source, electricity prices are assumed at a higher margin. In another New Zealand hydrogen report, an electricity price 
of NZ\$ 75/MWh was used in the techno-economic assumption (Concept Consultancy, 2019). This price approximately reflects the current time-weighted average (TWA) prices of new baseload generation. This assumption is also made from an optimistically high share of renewables in the current energy mix (Concept Consultancy, 2019). For this study, a higher electricity base cost of NZ\$100/MWh is chosen, assuming it can cover the TWA of future new generation across all renewable energy sources with some margins.

\subsubsection{Capital cost}

The second most influential factor is capital cost (CAPEX), especially electrolyser costs. System optimization is necessary to avoid incorrect sizing of system components in the green hydrogen system (Gutiérrez-Martín et al., 2010; Mohammadi \& Mehrpooya, 2018; Rahil \& Gammon, 2017). However, optimization cannot reduce unit capital costs in electrolysers that depend on rare materials, such as PEM electrolysers (Mohammadi \& Mehrpooya, 2018). Apart from optimization, economies of scale (Linnemann \& Steinberger-Wilckens, 2007) and technology learning rates will also likely have an effect on capital costs and their expected reductions in the future.

In this study, the assumptions made by Concept Consultancy are used. The capital cost is pegged at NZ\$1400/kW for the current scenario. This is assumed to reduce by $3 \%$ annually through a consistent technology learning rate of $13-15 \%$. This assumption is consistent with other hydrogen groups (Concept Consultancy, 2019; Hydrogen Council, 2020).

\subsubsection{Utilisation rate}

Utilisation rate is still significant in the overall price of hydrogen, despite not having a direct share in the hydrogen per unit cost. Utilisation rate is the ratio between the estimated and maximum electrolyser capacity if it were to operate non-stop. Utilisation rate affects the system sizing of hydrogen production systems as part of the core techno-economic analysis (Bertuccioli et al., 2014; MBIE, 2019b). Higher utilisation means that electrolyser investment cost is maximized, and therefore the hydrogen cost lowers (Bruce et al., 2018). Higher utilisation rates can be achieved on a grid-connected setup with a diversified supply of RE input electricity (Thomas et al., 2016). In the case of dedicated RE hydrogen production, however, the utilisation rate is usually low, for example, when using a dedicated wind farm. This is because electrolyser utilisation is limited by the capacity factor of the off-grid, dedicated RE (Concept Consultancy, 2019; Hinkley et al., 2016). This study assumes a utilization rate of $85 \%$ as a result of diversified RE electricity input from consented, yet unbuilt, RE projects.

\subsubsection{Future cost reductions}

There is a global trend of reducing electricity costs from RE sources. In 2018, electricity costs from new RE generation were lower than newly built conventional fossil fuel plants. The weighted average electricity cost across RE sources was also at its lowest in the same year. Installation costs for RE generating plants are expected to continue to decrease beyond 2020. In particular, observed reductions in electricity cost for geothermal is $1 \%, 11 \%$ for hydro, and $13 \%$ for onshore wind (IRENA, 2019). 
Electrolyser costs continue to decrease as more products are manufactured over time, with improvement in overall efficiencies and economies of scale. Moreover, government support for climate change mitigation and decarbonization also plays a role in making green hydrogen economically competitive (Bertuccioli et al., 2014).

Technology learning makes it possible to project lower electrolyser investment costs in the future. In 2015, the learning rate for both alkaline and PEM electrolysers was $18 \%$. The rate of cost reduction for electrolysers is also coupled with market uptake by 2030 . Continued research and development efforts can significantly improve the economic outlook of electrolyser technologies by up to $24 \%$ (Schmidt et al., 2017). Saba et al. (2018) compared over 60 electrolyser cost studies for PEM electrolysers. Figure 2.4 suggests an expected lowering of investment costs for electrolysers. Cost comparison is pegged in 2017 Euro with adjustment for inflation, and balance of plant is not included in the estimation. Variations in the estimated values for PEM electrolysers are more prevalent, as alkaline electrolysers have reached commercialization before PEM electrolysers. PEM investment estimates are also lower in the year 2030. Market acceptance and further technology improvements are suggested to improve the future electrolyser investment outlook (Saba, Müller, Robinius, \& Stolten, 2018).

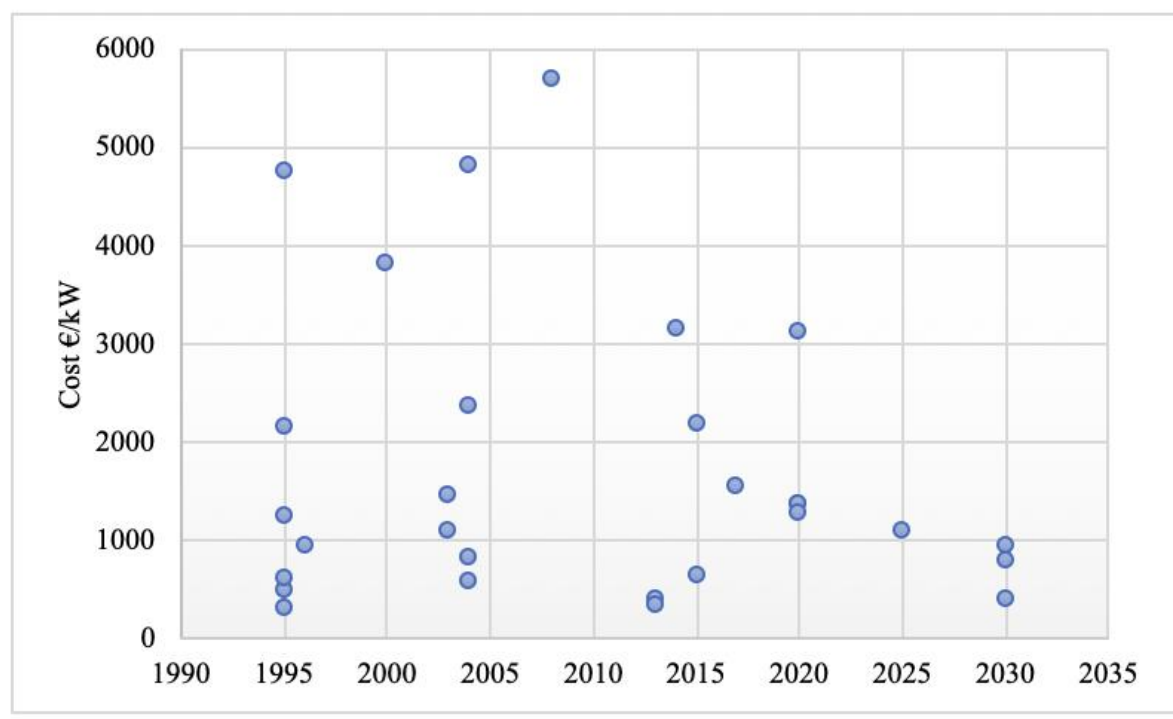

Figure 2.4. Cost projections for PEM electrolysers from 1992 through to 2030. From Saba et al. (2018).

\subsection{Conclusion}

This chapter has discussed the techno-economic assumptions that shape the green hydrogen fuel analysis. The discussion was organised according to the theme of each research question.

- Fuel cell vehicles are on the rise in some countries, which is beneficial in initiating consumer interest. Heavy vehicles are seen as the "low-hanging fruit" for hydrogen fuel. Hydrogen trucks can also take advantage of technology improvements in fuel cell systems. 
- In the sizing of hydrogen demand, a PEM electrolyser is chosen for the technoeconomic analysis as it can withstand operation under intermittent RE electricity supply.

- New Zealand has a strong and growing RE share in the electricity grid. This is a positive indication that a RE-sourced electrolytic hydrogen production may be feasible.

- Selection of a particular hydrogen production system in a form of refuelling stations improves the feasibility of a dedicated grid connected RE to supply electricity for hydrogen production.

- Hydrogen cost is calculated using the concept of levelized cost. It is a simple way of calculating the per unit cost of hydrogen production. Electricity cost, CAPEX and utilization rate are the three main factors that influence the cost of hydrogen.

Table 2.5 summarizes the important techno-economic assumptions for the green hydrogen fuel analysis.

Table 2.5. Summary of techno-economic assumptions

\begin{tabular}{|l|l|}
\hline \multicolumn{1}{|c|}{ Parameter } & \multicolumn{1}{c|}{ Assumption } \\
\hline Electrolyser type & PEM electrolyser \\
\hline Hydrogen application & Transport - fuel cell heavy vehicles \\
\hline Hydrogen demand basis & Diesel consumption of VHVs \\
\hline Electricity source & Purely RE \\
\hline Electricity source connection & Grid-connected, embedded/dedicated \\
\hline Production system & $\begin{array}{l}\text { Large-scale } \\
\text { Decentralised }\end{array}$ \\
\hline Hydrogen cost calculation & Levelized cost (discounted cash flow approach) \\
\hline Electricity cost & NZ\$ 100/MWh \\
\hline CAPEX & NZ\$ 1400/kWh \\
\hline Utilisation rate & $85 \%$ \\
\hline
\end{tabular}




\section{Chapter 3 - Methodology and initial results}

The feasibility of hydrogen as a form of green fuel for the very heavy vehicle (VHV) fleet in New Zealand was assessed using the following approach: (1) establishing the hydrogen demand, (2) sizing the renewable energy sources available, and (3) determining the price of hydrogen (Figure 3.1). The hydrogen demand for VHVs was determined by considering the replacement of the equivalent in diesel fuel consumption, using data from the 2017 calendar year. The size of the renewable generation to power hydrogen production was estimated from additional generating facilities with consented status. Lastly, the corresponding price of hydrogen was calculated based on the concept of levelized cost (G. Genç et al., 2012; M. S. Genç et al., 2012).

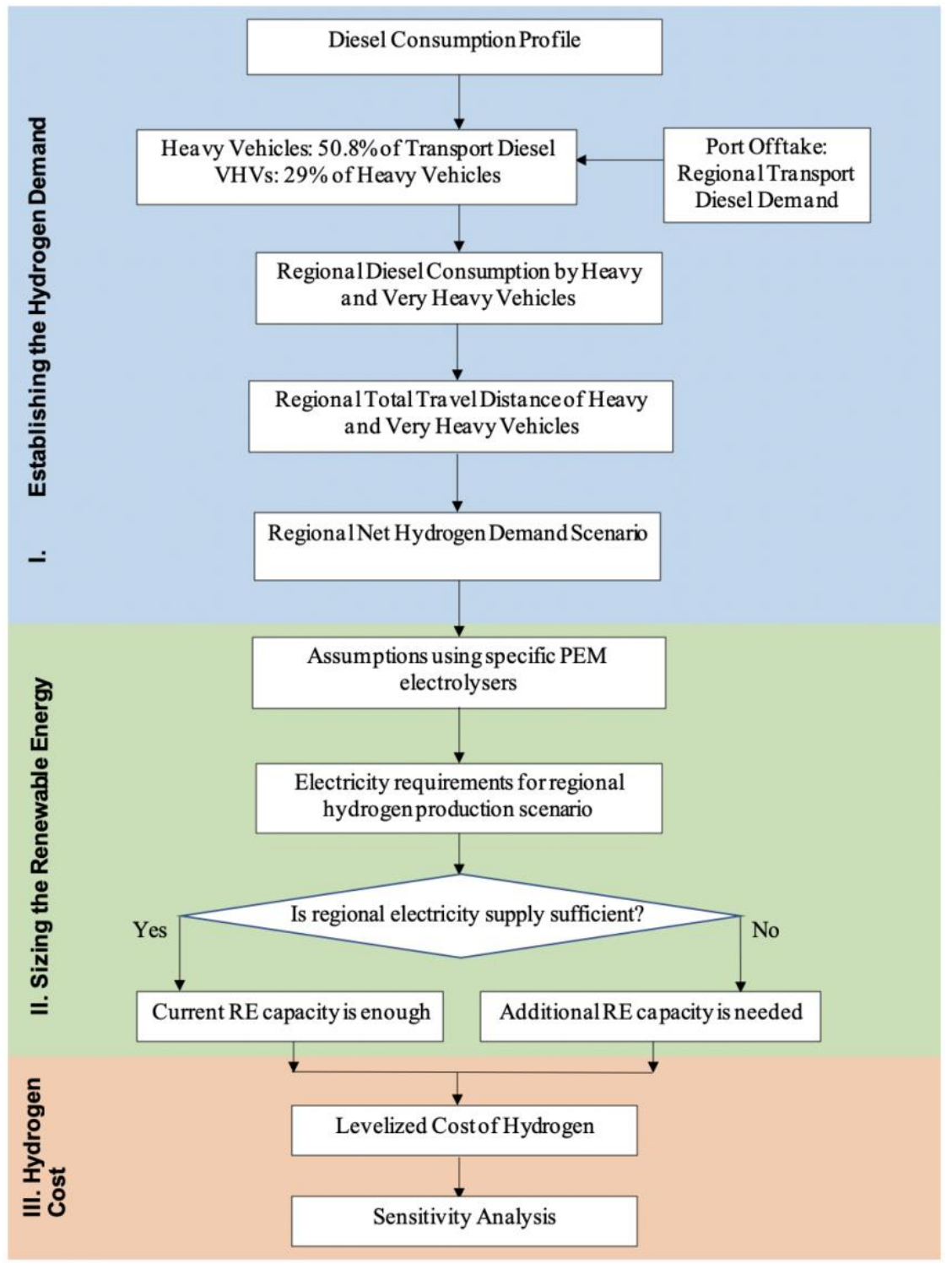

Figure 3.1. Methodology schematic diagram 


\subsection{Information used}

Information on national and regional diesel demand (regional port offtake) was sourced from the energy balances and 2017 calendar year report from the Ministry of Business, Innovation and Employment (MBIE, 2018). This was used to estimate the kilometres travelled by VHVs and the equivalent hydrogen demand. Wholesale electricity prices ${ }^{6}$, existing ${ }^{7}$ and additional renewable energy capacity ${ }^{8}$ were obtained from the Electricity Authority (EA) via the EA Market Information website. Techno-economic assumptions were based on the methodology used in the Hydrogen in New Zealand report (Concept Consulting, 2019). This report includes a green hydrogen cost model, diesel consumption of heavy and "very" heavy vehicles, and cost assumptions including capital and maintenance costs.

Reports from other expert groups, such as the International Renewable Energy Agency (IRENA), the International Energy Agency (IEA) Hydrogen, the Hydrogen Council, WaterstofNet (Power-to-gas roadmap report), Fuel Cells and Hydrogen Joint Undertaking (FCH JU) and Australia's Commonwealth Scientific and Industrial Research Organisation (CSIRO), were also reviewed for information on electrolyser technology, cost assumptions, and the future direction of green hydrogen fuel. The values from the Hydrogen in New Zealand report (Concept Consultancy, 2019) used in this study were cross-checked with the values from these reports and were found to be consistent. A summary of techno-economic assumption values used throughout the calculations is provided in Table 3.1.

\footnotetext{
${ }^{6}$ https://www.emi.ea.govt.nz/Wholesale/Reports/ (2017 dataset)

${ }^{7}$ https://www.emi.ea.govt.nz/Wholesale/Datasets/Generation/Generation_fleet/Existing

${ }^{8} \mathrm{https} / / / \mathrm{www}$.emi.ea.govt.nz/Wholesale/Datasets/Generation/Generation_fleet/Proposed
} 
Table 3.1. Techno-economic assumptions

\begin{tabular}{|c|c|c|c|}
\hline Parameter & Unit of measure & Value & Source \\
\hline Electrolyser CAPEX & $\mathrm{NZ} \$ / \mathrm{kW}$ & 1400 & Concept Consultancy (2019) \\
\hline Electrolyser OPEX & $\%$ of CAPEX & $5 \%$ & Concept Consultancy (2019) \\
\hline Useful Life & Years & 20 & Concept Consultancy (2019) \\
\hline Discount Rate & $\%$ & $6 \%$ & Concept Consultancy (2019) \\
\hline Wholesale Electricity & NZ\$/MWh & 100 & $\begin{array}{l}\text { Assumption, } 2017 \text { average } \\
\text { wholesale electricity price from } \\
\text { EMI }\end{array}$ \\
\hline Storage cost & $\mathrm{NZ} \$ / \mathrm{kg} \mathrm{H}$ & 0.5 & Concept Consultancy (2019) \\
\hline Diesel Travel Distance & litres / 100kM & 43 & (Collier et al., 2019) \\
\hline $\begin{array}{l}\text { Hydrogen } \quad \text { Demand } \\
\text { Conversion }\end{array}$ & $\mathrm{kg} / 100 \mathrm{kM}$ & 8 & $\begin{array}{l}\text { Indicative conversion values } \\
\text { from Hyundai and Esoro Trucks }\end{array}$ \\
\hline $\begin{array}{l}\text { MJ to } \mathrm{kg} \mathrm{H}_{2} \text { Conversion } \\
\text { (assuming LHV) }\end{array}$ & $\mathrm{MJ} / \mathrm{kg} \mathrm{H}$ & 120 & (IRENA, 2018a) \\
\hline $\begin{array}{l}\text { Hydrogen } \mathrm{kg} \text { to } \mathrm{Nm}^{3} \\
\text { Conversion }\end{array}$ & $\mathrm{Nm}^{3} / \mathrm{kg}$ & 11.1 & (IRENA, 2018a) \\
\hline Electricity network loss & $\%$ & 4 & Concept Consultancy (2019) \\
\hline $\begin{array}{l}\text { Electricity network } \\
\text { charges }\end{array}$ & $\mathrm{NZ \$ /MWh}$ & 0.000031 & Concept Consultancy (2019) \\
\hline
\end{tabular}

\subsection{Establishing the hydrogen demand}

The amount of green hydrogen to be produced was assumed to be proportional to the amount of diesel fuel consumed by the VHV fleet in 2017. The basis is the travel distance equivalent per unit of diesel fuel in VHVs. The calculation was refined at a regional (ports) level, and the choice of PEM electrolyser was specified regionally, in conjunction with consented regional RE projects.

According to the Energy in New Zealand report, the total diesel consumption in 2017 was 134.59 PJ. Of this, diesel for transportation was $99.65 \mathrm{PJ}$, or $74 \%$ of the total (p. 14). Heavy vehicles consumed $50.62 \mathrm{PJ}$, equivalent to $50.8 \%$ of transport diesel and $37.6 \%$ of total diesel (MBIE, 2018). Concept Consultancy reports that $29 \%$ of heavy vehicle transport diesel is consumed by VHVs, whose gross mass is more than 30 tonnes. This corresponds to $14.7 \mathrm{PJs}$ or $11 \%$ of the total consumed diesel in 2017 (Concept Consultancy, 2019).

Regional port offtake (Figure 3.2) is an approximate measure of regional fuel consumption, although some fuel is transported between regions (MBIE, 2018). Another feature of regional ports is that some ports service more than one administrative region, such as Mount Maunganui (Waikato and Bay of Plenty regions), Nelson (Marlborough, Nelson, Tasman and 
West Coast regions), Napier (Gisborne and Hawkes Bay regions), and New Plymouth (Manawatu-Wanganui and Taranaki regions). Canterbury is served by both the Christchurch and Timaru ports.

Table 3.2. Regions serviced by each port

\begin{tabular}{|l|l|}
\hline Regional Ports & Serviced Regions \\
\hline Auckland & Auckland \\
\hline Christchurch and Timaru & Canterbury \\
\hline Wellington & Wellington \\
\hline Mount Maunganui & Waikato, Bay of Plenty \\
\hline Dunedin & Otago \\
\hline Whangarei & Northland \\
\hline Nelson & Marlborough, Nelson, Tasman, West Coast \\
\hline Napier & Gisborne, Hawkes Bay \\
\hline Bluff & Southland \\
\hline New Plymouth & Manawatu-Wanganui, Taranaki \\
\hline
\end{tabular}

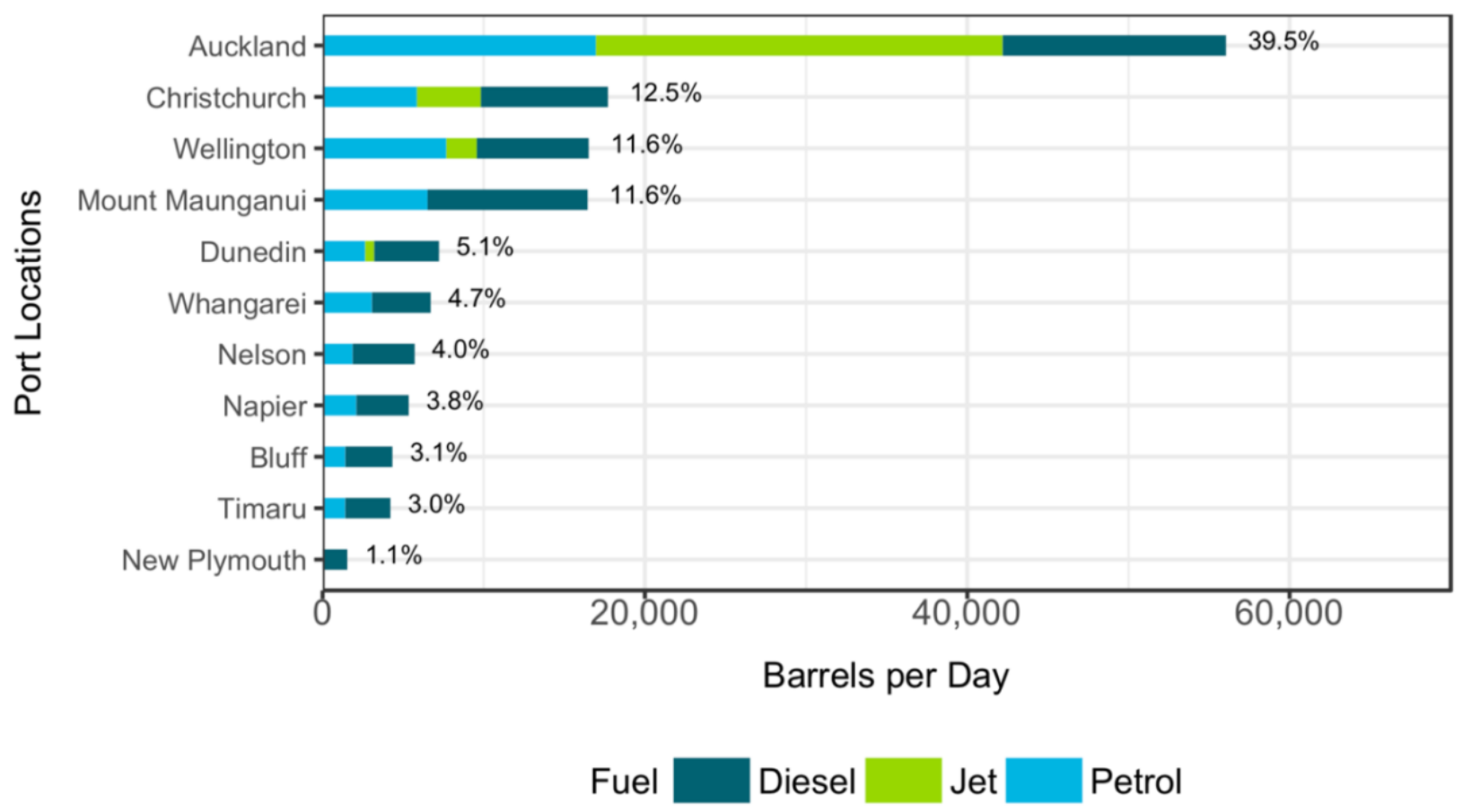

Figure 3.2. Port offtakes for 2107 calendar year. From MBIE (2018; p. 35)

In Table 3.3, regional port offtake data is presented in barrels per day. Percentages are calculated for each regional port, and this is used to approximate regional diesel demand for 
VHVs. This calculation therefore assumes that the $14.7 \mathrm{PJ}$ diesel demand for VHVs is proportionally spread according to the overall transport diesel demand.

Table 3.3. Annual (2017) diesel demand for VHVs per region

\begin{tabular}{|l|l|l|l|l|}
\hline Regional Ports & $\begin{array}{l}\text { Diesel Demand } \\
\text { (Thousand } \\
\text { Barrels per day) }\end{array}$ & $\begin{array}{l}\text { Diesel } \\
\text { Demand } \\
\text { Percentage }\end{array}$ & $\begin{array}{l}\text { Diesel } \\
\text { Demand } \\
\text { (Petajoules) }\end{array}$ & $\begin{array}{l}\text { Diesel } \\
\text { Demand } \\
\text { (Megalitres) }\end{array}$ \\
\hline Auckland and & 13.9 & $22.4 \%$ & 3.30 & 85.4 \\
\hline $\begin{array}{l}\text { Christchurch } \\
\text { Timaru }\end{array}$ & 10.8 & $17.5 \%$ & 2.57 & 66.4 \\
\hline Wellington & 7.0 & $11.2 \%$ & 1.65 & 42.8 \\
\hline Mount Maunganui & 10.1 & $16.3 \%$ & 2.39 & 62.0 \\
\hline Dunedin & 4.0 & $6.5 \%$ & 0.96 & 24.9 \\
\hline Whangarei & 3.7 & $5.9 \%$ & 0.87 & 22.6 \\
\hline Nelson & 4.8 & $7.8 \%$ & 1.15 & 29.8 \\
\hline Napier & 3.2 & $5.2 \%$ & 0.77 & 20.0 \\
\hline Bluff & 2.9 & $4.8 \%$ & 0.70 & 18.1 \\
\hline New Plymouth & 1.4 & $2.2 \%$ & 0.33 & 8.4 \\
\hline TOTAL & 61.8 & $100 \%$ & 14.7 & 380.6 \\
\hline
\end{tabular}

Conversion ratios from petajoule $(\mathrm{PJ})$ to litre $(\mathrm{I})$ are reported by MBIE. Diesel has a density of $0.84 \mathrm{~kg} / \mathrm{l}$ and its gross calorific value is $45.98 \mathrm{MJ} / \mathrm{kg}$ (MBIE, 2018).

The equivalent travel kilometres (Table 3.4) are determined from the consumed volume of diesel, assuming a constant fuel consumption rate of 5.5 miles per gallon, or 43 litres per 100 $\mathrm{km}$. This method was adopted from Collier et al. (2019). This consumption rate was derived from 79 heavy-duty diesel trucks manufactured between 2008 and 2015. The consumption of $5.5 \pm 1.7$ miles per gallon was reported to be consistent with other heavy-duty fleet studies (Collier et al., 2019). Travel distances were calculated using (1).

$$
\text { Travel Distance }=\text { Diesel Demand (in Litres) } x \frac{100 \mathrm{~km}}{43 \text { Litres }}(\mathrm{km})
$$


Table 3.4. Estimated equivalent annual (2017) kilometre travel distance of the VHV fleet

\begin{tabular}{|l|l|l|}
\hline Regional Ports & $\begin{array}{l}\text { Diesel Demand } \\
\text { (Megalitres) }\end{array}$ & $\begin{array}{l}\text { Travel Distance } \\
\text { (Million kilometres) }\end{array}$ \\
\hline Auckland & 85,4 & 198.7 \\
\hline Christchurch and Timaru & 66,5 & 154.6 \\
\hline Wellington & 42,8 & 99.6 \\
\hline Mount Maunganui & 62,0 & 144.1 \\
\hline Dunedin & 24,9 & 57.9 \\
\hline Whangarei & 22,6 & 52.7 \\
\hline Nelson & 29,9 & 69.4 \\
\hline Napier & 20,0 & 46.4 \\
\hline Bluff & 18,1 & 42.1 \\
\hline New Plymouth & 8,4 & 19.6 \\
\hline TOTAL & 380,6 & 885.1 \\
\hline
\end{tabular}

The estimated net hydrogen demand (Table 3.5) is then calculated from the travel kilometres using equation (2), assuming a constant consumption rate for hydrogen vehicles. Several models of hydrogen trucks were considered to estimate the kilogram to kilometre conversion ratio. A HyundaiTM $4 \times 2$ Cargo Truck has a stated hydrogen consumption of $8.2 \mathrm{~kg} / 100$ kilometres (Hyundai Motors New Zealand, 2019), while an Esoro Hydrogen Truck has a hydrogen consumption range of $7.5-8 \mathrm{~kg} / 100$ kilometres (ESORO, 2017). An indicative hydrogen consumption of $8 \mathrm{~kg} / 100$ was adopted in the calculation. A conversion of 0.09 $\mathrm{kg} / \mathrm{Nm}^{3}$ (IRENA, 2018a) is used to determine the hydrogen production on a volume basis.

$$
\text { Net Hydrogen Demand }=\text { Travel Distance } \mathrm{x} \frac{8 \mathrm{~kg}}{100 \mathrm{~km}}(\mathrm{~kg})
$$


Table 3.5. Estimated annual (2017) net hydrogen demand for VHVs

\begin{tabular}{|l|l|l|l|}
\hline Regional Ports & $\begin{array}{l}\text { Travel Distance } \\
\text { (Million } \\
\text { kilometres) }\end{array}$ & $\begin{array}{l}\text { Hydrogen } \\
\text { Demand (Million } \\
\text { kilograms) }\end{array}$ & $\begin{array}{l}\text { Hydrogen } \\
\text { Demand (Million } \\
\mathrm{Nm}^{3} \text { ) }\end{array}$ \\
\hline Auckland & 198.7 & 15.9 & 176.4 \\
\hline Christchurch and Timaru & 154.6 & 12.4 & 137.3 \\
\hline Wellington & 99.6 & 8.0 & 88.4 \\
\hline Mount Maunganui & 144.1 & 11.5 & 128.0 \\
\hline Dunedin & 57.9 & 4.6 & 51.4 \\
\hline Whangarei & 52.7 & 4.2 & 46.8 \\
\hline Nelson & 69.4 & 5.6 & 61.6 \\
\hline Napier & 46.4 & 3.7 & 41.2 \\
\hline Bluff & 42.1 & 3.4 & 37.4 \\
\hline New Plymouth & 19.6 & 1.6 & 17.4 \\
\hline TOTAL & 885.1 & 70.8 & 786.0 \\
\hline
\end{tabular}

\subsection{Renewable electricity source}

This part of the methodology examines the current status and addition of renewable sources in comparison to the regional energy requirements to produce hydrogen for the VHV fleet. Electrolyser energy requirements are estimated using consumption data from specific electrolyser manufacturers.

Several electrolyser models were selected to obtain an equivalent energy consumption per $\mathrm{Nm}^{3}$ of hydrogen. The HyLYZER ${ }^{\circledR}$ PEM electrolyser from Hydrogenics ${ }^{\mathrm{TM}}$ has a reported energy consumption of $5.4 \mathrm{kWh} / \mathrm{Nm}^{3}$ of hydrogen produced, while the SiLYZER ${ }^{\circledR}$ PEM electrolyser from Siemens ${ }^{\mathrm{TM}}$ has an indicative electricity consumption of $5.6 \mathrm{kWh} / \mathrm{Nm}^{3}$ (Hydrogenics, 2018; Siemens AG, 2017). From this, an estimate of $5.5 \mathrm{kWh} / \mathrm{Nm}^{3}$, or $61 \mathrm{kWh} / \mathrm{kg}$, was adopted for the calculations. The calculation using equations (3) (for PJ) and (4) (for GWh) assumes the electrolyser efficiency, or losses, are included in the electrolyser energy consumption.

$$
\begin{aligned}
& \text { Energy Content }=\text { Hydrogen Demand (in } \mathrm{kg}) \times \frac{120 \mathrm{MJ}}{\mathrm{kg}} \times \frac{1 \mathrm{PJ}}{1000000000 \mathrm{MJ}} \\
& \text { Electrolyser Energy Input }=\text { Hydrogen Demand } x \frac{61 \mathrm{kWh}}{\mathrm{kg}} \times \frac{1 \mathrm{GWh}}{1000000 \mathrm{kWh}}
\end{aligned}
$$


Table 3.6. Estimated annual (2017) electrolytic energy consumption per region

\begin{tabular}{|l|l|l|l|}
\hline Regional Ports & $\begin{array}{l}\text { Hydrogen } \\
\text { Demand (Million } \\
\left.\mathrm{Nm}^{3}\right)\end{array}$ & $\begin{array}{l}\text { Equivalent Energy } \\
(\mathrm{GWh})\end{array}$ & $\begin{array}{l}\text { Equivalent Energy } \\
(\mathrm{PJ})\end{array}$ \\
\hline Auckland & 176.4 & 1008 & 1.91 \\
\hline Christchurch and Timaru & 137.3 & 785 & 1.48 \\
\hline Wellington & 88.4 & 486 & 0.96 \\
\hline Mount Maunganui & 128.0 & 505 & 1.38 \\
\hline Dunedin & 51.4 & 731 & 0.56 \\
\hline Whangarei & 46.8 & 257 & 0.51 \\
\hline Nelson & 61.6 & 294 & 0.67 \\
\hline Napier & 41.2 & 267 & 0.45 \\
\hline Bluff & 37.4 & 352 & 0.40 \\
\hline New Plymouth & 17.4 & 236 & 0.19 \\
\hline TOTAL & 786.0 & 4,492 & 8.5 \\
\hline
\end{tabular}

Required regional electrolyser capacities (Table 3.7) were calculated using equation (5). Calculation of the electrolyser capacity requires the utilisation factor. The utilisation factor is the ratio between the actual and potential electrolyser capacity if it were to operate continuously. In the Hydrogen in New Zealand report (Concept Consultancy, 2019), a utilisation factor of $85 \%$ is assumed for a grid-connected hydrogen production case. This assumption implies that hydrogen is produced on a "fairly consistent basis". In the current study, a uniform value of utilisation factor simplifies the levelized cost calculations. Also, a grid network loss of $4 \%$ is considered in the calculation of electrolyser energy demand, as shown in Table 3.10. For the two electrolyser models, HyLYZER ${ }^{\circ}$ has a 5-MW model while SiLYZER ${ }^{\oplus}$ has a stackable skid of $1.25 \mathrm{MW}$. The number of units for each electrolyser type are also calculated (Table 3.7) in order to generate a rough estimate of how many units are needed in each region.

$$
\text { Required Capacity }=\left(\begin{array}{c}
\text { Equivalent } \\
\text { Energy }(G W h)
\end{array}\right) \times \frac{1,000 M W}{1 G W} \times \frac{1}{(8760 h)(\% \text { Utilisation Factor })}
$$


Table 3.7. PEM electrolyser required capacities

\begin{tabular}{|l|l|l|l|}
\hline Regional Ports & $\begin{array}{l}\text { Required MW } \\
\text { Capacity }\end{array}$ & HyLYZER ${ }^{\circledR}$ units & SiLYZER ${ }^{\circledR}$ units \\
\hline Auckland and & 224 & 45 & 179 \\
\hline $\begin{array}{l}\text { Christchurch } \\
\text { Timaru }\end{array}$ & 174 & 35 & 139 \\
\hline Wellington & 112 & 22 & 90 \\
\hline Mount Maunganui & 162 & 32 & 130 \\
\hline Dunedin & 65 & 13 & 52 \\
\hline Whangarei & 59 & 12 & 48 \\
\hline Nelson & 78 & 16 & 63 \\
\hline Napier & 52 & 10 & 42 \\
\hline Bluff & 48 & 10 & 38 \\
\hline New Plymouth & 22 & 4 & 18 \\
\hline TOTAL & 998 & 200 & 799 \\
\hline
\end{tabular}

The Electricity Authority maintains a 2015 record of existing generation plants ${ }^{9}$ including gridconnected renewables (Table 3.8). This data is derived from the 2015 existing generation plant from the Electricity Authority. Renewable generation on the North Island is dominated by geothermal and hydroelectric sources, which are mostly found in the Waikato region. Manawatu-Whanganui and Wellington also have rich wind resources. Generation in the South Island is primarily hydropower, notably in Canterbury and Otago. Some regions do not have grid-connected renewables. Information on installed capacity in $\mathrm{MW}$ and annual typical generation in GWh is available for each existing generating facility.

\footnotetext{
${ }^{9}$ https://www.emi.ea.govt.nz/Wholesale/Datasets/Generation/Generation_fleet/Existing
} 
Table 3.8. Existing grid renewable sources per region

\begin{tabular}{|l|l|l|l|}
\hline Region & Renewables & Capacity (MW) & $\begin{array}{l}\text { Annual Generation } \\
\text { (GWh) }\end{array}$ \\
\hline Auckland & & & \\
\hline Canterbury & hydro & 819 & 3840 \\
\hline Wellington & wind & 143 & 550 \\
\hline Waikato & hydro, geothermal & 2407.1 & 11773 \\
\hline Bay of Plenty & hydro, geothermal & 334 & 1637 \\
\hline Otago & hydro & 1800 & 8278 \\
\hline Northland & & & \\
\hline $\begin{array}{l}\text { Marlborough-Nelson- } \\
\text { Tasman }\end{array}$ & hydro & 3.8 & 17 \\
\hline West Coast & hydro & 6.5 & 30 \\
\hline Gisborne & & & \\
\hline Hawke's Bay & & & 5300 \\
\hline Southland & hydro, wind & 908 & 769 \\
\hline Manawatu-Whanganui & hydro, wind & 225.75 & 318 \\
\hline Taranaki & hydro & 30.7 & \\
\hline New Zealand Total & & & \\
\hline
\end{tabular}

From the nameplate capacity and annual generation of existing grid renewable sources, the capacity factor for each renewable source can be calculated using (6).

$$
\% \text { Capacity Factor }=\frac{\text { Typical Annual Generation }(G W h) \times 1000}{365 \times 24 \times \text { Installed Capacity }(\mathrm{MW})}
$$

Capacity factors are different for every renewable generating station in each region. In order to obtain uniformity, mean capacity factors by generation type were calculated in each region. This in turn was used to calculate the estimated annual generation in GWh of the additional renewable sources per source per region. This calculation assumes that the capacity factor for each type of renewable source varies with regional location. The allocation of capacity factors by source and region for additional consented renewables is based on the capacity factor of existing renewables in the same region. Other additional renewables have allocated capacity factors of the same type of renewable source from its adjacent region. The same formula for the capacity factor (6) was used to obtain values for the estimated energy generation. The average capacity factor for all additional renewable sources was also assumed to be the utilisation factor. This is following a dedicated RE hydrogen production setup. 
Table 3.9 details the consented yet unbuilt renewable energy capacity in each region. This information was derived from the 26 May 2019 update of proposed generation plants ${ }^{10}$ by the Electricity Authority. These projects have a consented status, with the earliest commissioning year of 2019 (6.5 MW hydro in Otago) and the latest known tentative construction year between 2023 through to 2033 (860 MW wind in Wellington) (MBIE, 2019c). The estimated generation in GWh was calculated from indicative nameplate capacities of additional consented renewable energy projects using (7).

Additional RE $=$ Plant Capacity (in MW) $\times 8760 \times$ Capacity Factor $\times \frac{1 G W h}{1000 M W h}$

Table 3.9. Consented yet unbuilt renewable energy projects per region

\begin{tabular}{|l|l|l|l|l|}
\hline Region & $\begin{array}{l}\text { Capacity } \\
(\mathrm{MW})\end{array}$ & $\begin{array}{l}\text { Renewable } \\
\text { Source }\end{array}$ & $\begin{array}{l}\text { Capacity } \\
\text { Factor }\end{array}$ & $\begin{array}{l}\text { Estimated } \\
\text { Generation (GWh) }\end{array}$ \\
\hline Auckland & 18 & Wind & $39.9 \%$ & 63 \\
\hline Canterbury & 16 & Hydro & $59.8 \%$ & 84 \\
\hline Wellington & 1019 & Wind & $43.9 \%$ & 3918 \\
\hline Waikato & 250 & Geothermal & $78.5 \%$ & 1720 \\
\hline Bay of Plenty & 98 & Wind & $39.9 \%$ & 343 \\
\hline Otago & 6.5 & Hydro & $48.9 \%$ & 28 \\
\hline $\begin{array}{l}\text { Northland } \\
\text { Nelson-Tasman }\end{array}$ & 70.5 & Wind & $39.4 \%$ & 566 \\
\hline West Coast & 106 & Geothermal & $78.5 \%$ & 365 \\
\hline Gisborne & & Hydro & $51.1 \%$ & 316 \\
\hline Hawke's Bay & & & $52.7 \%$ & 489 \\
\hline $\begin{array}{l}\text { Manawatu- } \\
\text { Wanganui }\end{array}$ & 428 & Wind & $39.2 \%$ & 1469 \\
\hline Taranaki & 135 & Wind & $39.2 \%$ & 464 \\
\hline TOTAL & $\mathbf{2 3 6 4}$ & & $\mathbf{4 9 . 4 \%}$ & $\mathbf{9 8 2 5}$ \\
\hline
\end{tabular}

A comparison between electrolyser energy demand and additional consented renewable energy (Table 3.10) shows that the additional renewable energy capacity is enough to supply electricity to the electrolysers. Some regions do not have additional renewable energy capacity. Connection to the electricity grid from adjacent regions with abundant indicative

10

https://www.emi.ea.govt.nz/Wholesale/Datasets/Generation/Generation_fleet/Proposed 
generation is viable in order to service hydrogen production from regions like Bay of Plenty, Gisborne, Hawke's Bay and Southland.

Table 3.10. Regional electrolyser energy demand and additional renewable generation

\begin{tabular}{|c|c|c|}
\hline Region & $\begin{array}{l}\text { Electrolyser Energy } \\
\text { Demand (GWh) }\end{array}$ & $\begin{array}{l}\text { Additional Renewable } \\
\text { Generation (GWh) }\end{array}$ \\
\hline Auckland & 1008 & 63 \\
\hline Canterbury & \multirow{2}{*}{785} & 84 \\
\hline West Coast & & 489 \\
\hline Wellington & 505 & 3918 \\
\hline Waikato & \multirow{2}{*}{731} & 1909 \\
\hline Bay of Plenty & & \\
\hline Otago & 294 & 594 \\
\hline Northland & 267 & 365 \\
\hline $\begin{array}{l}\text { Marlborough-Nelson- } \\
\text { Tasman }\end{array}$ & 352 & 316 \\
\hline Gisborne & \multirow{2}{*}{236} & \\
\hline Hawke's Bay & & \\
\hline Southland & 214 & \\
\hline Manawatu-Wanganui & \multirow{2}{*}{100} & 1469 \\
\hline Taranaki & & 464 \\
\hline TOTAL & 4492 & 9824 \\
\hline
\end{tabular}

\subsection{Hydrogen cost}

The calculation of levelized hydrogen cost considered the following: hydrogen production in a year, electrolyser capital cost, operations and maintenance costs, cost of electricity input, and the capital recovery factor of the electrolyser (Genç et al., 2012; Genç et al., 2012). Levelized cost does not include taxes and the inflation rate.

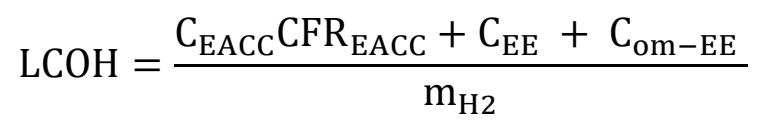

In which,

$$
\begin{gathered}
\mathrm{C}_{\mathrm{EACC}}=\mathrm{P}_{\text {rated }} \mathrm{I}_{\mathrm{E}} \\
C F R_{E A C C}=\frac{(1+\mathrm{r})^{\mathrm{n}} \mathrm{r}}{(1+\mathrm{r})^{\mathrm{n}}-1}
\end{gathered}
$$

Where 


$\begin{array}{ll}\text { LCOH } & \text { Levelized cost of hydrogen } \\ \mathrm{C}_{\mathrm{EACC}} & \text { Electrolyser capital cost } \\ \mathrm{CFR}_{\mathrm{EACC}} & \text { Capital recovery factor of electrolyser } \\ \mathrm{C}_{\mathrm{EE}} & \text { Cost of electricity input } \\ \mathrm{C}_{\mathrm{Om}-\mathrm{EE}} & \text { Operations and maintenance cost } \\ \mathrm{m}_{\mathrm{H} 2} & \text { Hydrogen production in a year } \\ \mathrm{P}_{\text {rated }} & \text { Electrolyser rated power } \\ \mathrm{I}_{\mathrm{E}} & \text { Electrolyser cost per KW } \\ r & \text { Discount rate } \\ \mathrm{n} & \text { System lifetime }\end{array}$

The green hydrogen model assumptions used by Concept Consultancy (2019) were mostly used in the calculations (Table 3.11). Selection of these parameters enables a comparison with another report in a New Zealand context.

Table 3.11. Hydrogen model assumptions derived from Concept Consultancy (2019)

\begin{tabular}{|l|l|}
\hline Electrolyser capital cost $(\mathrm{NZ} \mathbf{\$} / \mathrm{kW})$ & 1400, with $3 \%$ annual reduction rate \\
\hline Operations and maintenance & $5 \%$ of capital costs \\
\hline Discount rate & $6 \%$ \\
\hline System lifetime & 20 years \\
\hline Storage Cost & $0.50 \mathrm{NZ \$} / \mathrm{kg}$ \\
\hline Electricity network charge & $0.000031 \mathrm{NZ} / \mathrm{MWh}$ \\
\hline
\end{tabular}

Electrolyser capital cost, electricity input cost and utilisation rate were initially kept constant, but a sensitivity analysis was undertaken (see Chapter 4 - Discussion). Factors such as yearly hydrogen production demand (Table 3.6), electrolyser energy demand (Table 3.6) and electrolyser required capacity (Table 3.7 ) are specified per region.

The PEM electrolyser CAPEX is currently high as the technology has not yet reached commercial maturity (Concept Consultancy, 2019). However, it is expected to reduce annually by $3 \%$, reflecting the current technology cost reduction learning rate (Concept Consultancy, 2019; Hydrogen Council, 2020; Schmidt et al., 2017). Operations and maintenance costs (OPEX) are assumed to be a fixed percentage of the capital cost, which allows flexibility in the scalability of capital costs (i.e. a smaller CAPEX for small-scale hydrogen infrastructure corresponds to a smaller OPEX). This is consistent with other literature (Hinkley et al., 2016; IEA Hydrogen, 2015; Tractebel \& Hinicio, 2017). Storage cost is also considered from past literature, which assumes a daily replenishment cycle to keep the cost down (Concept Consultancy, 2019). The calculation assumes a wholesale electricity price of $100 \mathrm{NZ} \$ / \mathrm{MWh}$, 
obtained from higher margin 2017 average wholesale electricity prices ${ }^{11}$. This figure is higher than the $75 \mathrm{NZ} \$ / \mathrm{MWh}$ assumption in the Concept Consultancy report. A higher electricity cost approximates the higher time-weighted average (TWA) price of a new generating plant. Based on the initial calculation, the resultant costs were obtained (Table 3.12).

Table 3.12. Resultant costs (in NZ \$/kg H2)

\begin{tabular}{|l|l|}
\hline Electrolyser CAPEX & 1.00 \\
\hline Electrolyser OPEX & 0.57 \\
\hline Electricity cost & 6.34 \\
\hline Storage cost & 0.50 \\
\hline Hydrogen levelized cost & $\mathbf{8 . 4 2}$ \\
\hline
\end{tabular}

Electricity cost counts for the largest share in the hydrogen cost at $75 \%$. This is roughly consistent with the data from the Concept Consultancy report (2019). The Hydrogen production cost of $8.42 \mathrm{NZ} \$ / \mathrm{kg}$ is also approximately similar to the hydrogen cost data from the Concept Consultancy report (2019) for a large-scale hydrogen production that requires new renewable generation build at $9.1 \mathrm{NZ} \$ / \mathrm{kg}$.

From an earlier figure of $8 \mathrm{~kg} / 100 \mathrm{~km}$, a hydrogen production cost at $8.42 \mathrm{NZ} \$ / \mathrm{kg}$ would translate to $0.67 \mathrm{NZ} \$ / \mathrm{km}$. This value does not include taxes, inflation and retail margins.

\subsection{Conclusion}

The green hydrogen fuel scenario has been modelled in three steps: (1) establishing the hydrogen demand, (2) sizing the renewable energy source, and (3) determining the cost of hydrogen. Hydrogen demand was estimated from current diesel consumption in VHVs based on equivalent travel kilometres with the existing fleet. Port offtake data for diesel deliveries was used to assess hydrogen demand on a regional level. The sizing of additional consented renewable energy generation was also examined on a regional basis. This consented but unbuilt generation would be sufficient to supply the energy required for hydrogen production. Finally, a levelized hydrogen cost of $8.42 \mathrm{NZ} \$ / \mathrm{kg}$ was calculated. The LCOH provides a simple estimation of how much the green hydrogen fuel would cost at present.

This chapter has presented data from the modelled bottom-up calculations. The next chapter provides an in-depth narrative on the data presented in this chapter, as well as its significance in the New Zealand context. This includes a sanity check on the estimated hydrogen demand in comparison to diesel consumption in VHVs, as well as cost prospects for green hydrogen fuel in both the short and long term.

\footnotetext{
${ }^{11} \mathrm{https} / / \mathrm{www}$.emi.ea.govt.nz/Wholesale/Reports/
} 


\section{Chapter 4 - Results and discussion}

It is assumed that hydrogen demand will follow population and industry activities in the much same way as diesel does. In terms of equivalent energy, green hydrogen uses less energy than diesel for the same transport duty. The potential energy generation from consented yet unbuilt renewable energy (RE) generation projects is significantly more than the electrical energy required for hydrogen production to satisfy the VHV sector. The levelized cost of hydrogen, based on the current technology, is a little higher than current diesel pricing. However, future projections show a cost reduction for hydrogen production.

\subsection{Hydrogen demand}

The overall VHV annual (2017) hydrogen demand volume was calculated at about 71 million $\mathrm{kg}$ or 786 million $\mathrm{Nm}^{3}$. Diesel and hydrogen fuel can be compared using energy and travel kilometre efficiency. In terms of energy, the hydrogen demand is equivalent to $8.5 \mathrm{PJ}^{12}$ while for diesel it is 14.7 PJ (Concept Consultancy, 2019; MBIE, 2018). In terms of travel kilometre efficiency, diesel vehicles consume $16.6 \mathrm{~kJ} / \mathrm{km}$ while hydrogen consumption is estimated at $9.6 \mathrm{~kJ} / \mathrm{km}$ (Collier et al., 2019). This is an indication that hydrogen entails more efficient conversion of energy to useful motive power than diesel.

As stated in the previous chapter, prerequisites to calculating hydrogen demand are calculating diesel demand and then travel kilometres. The annual (2017) calculated travel distance equivalent of indicative diesel consumption in VHVs is 885 million $\mathrm{km}$. The travel kilometres are difficult to cross-check due to two reasons: 1 ) road user charges (RUC) count heavy vehicles in general, with no segregation per vehicle mass within the heavy vehicle category, and 2) RUC measurements for heavy vehicles are done only on state highways. This is the first limitation of the analysis.

Regional distribution of annual (2017) hydrogen demand (Figure 4.1) was mapped using QGIS. Auckland has the greatest hydrogen demand, followed by Mount Maunganui (Waikato and Bay of Plenty regions) and Canterbury. As discussed in Chapter 2, these regions also have the largest state highway networks, population and freight activities (Deloitte, 2017). At first glance, there is a rough consistency between regions with high hydrogen fuel demand and regions with more population, state highway networks, and economic productivity.

\footnotetext{
12 Low heating value
} 
Hydrogen Volume (Million kg)

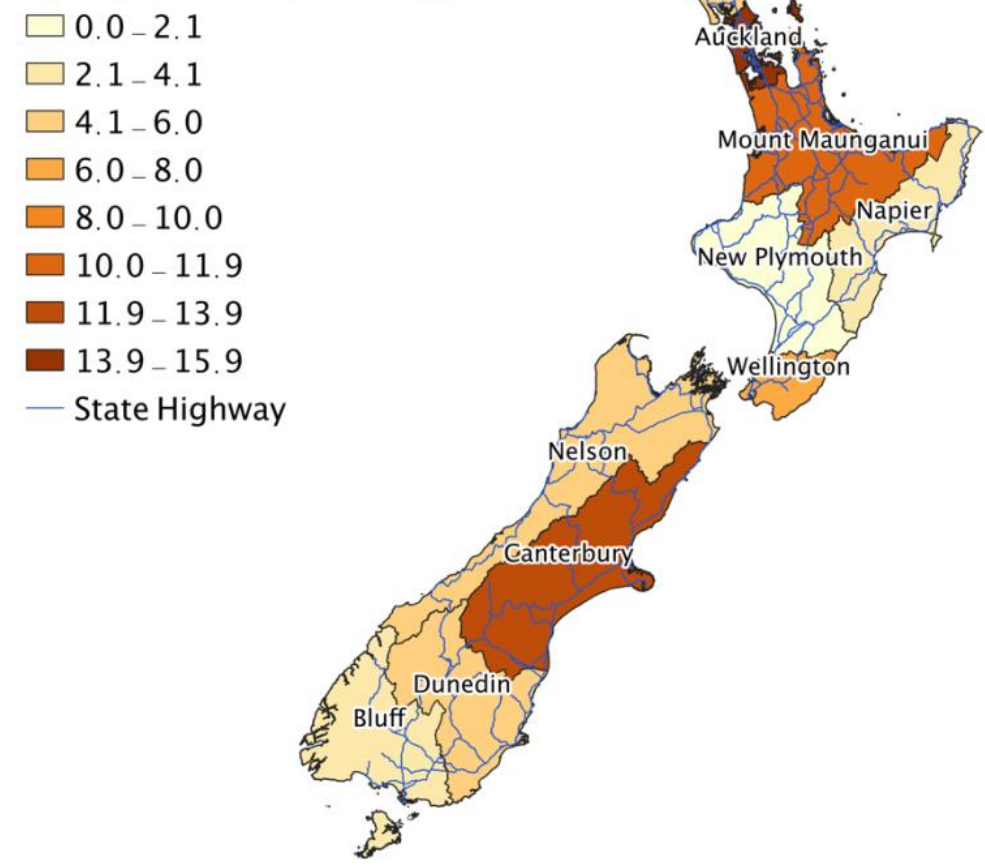

Figure 4.1. Regional demand for hydrogen fuel

\subsection{Renewable energy supply}

This research step begins with the calculation of hydrogen electrical energy equivalent. Annual (2017) hydrogen demand is calculated at 8.5 PJ or 4,492 GWh. The conversion value of $61 \mathrm{kWh} / \mathrm{kg}$ is assumed to be inclusive of losses within the electrolyser equipment.

The number of electrolyser units needed to supply the total annual hydrogen demand is shown in Figure 4.2. Regional electrolyser units give initial information on the extent of investment needed to supply the regional hydrogen demand. In terms of electrolyser choice, regions with high hydrogen demand may be better served with electrolysers of higher capacity (e.g. HyLYZER). In terms of scalability, regions with high hydrogen demand may have higher initial investment intensity. 


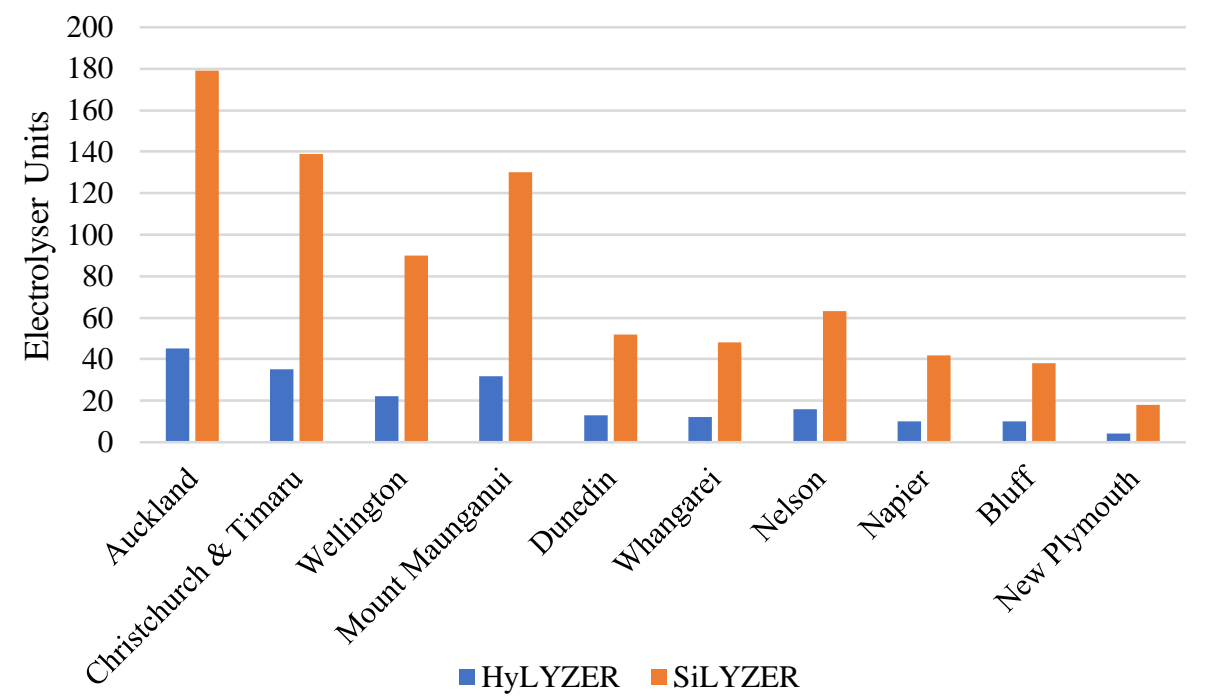

Figure 4.2. Electrolyser capacity in numbers of HyLYZER (5MW) and SilYZER (1.25 MW) units

Electrolyser capacity was calculated at an assumed utilization rate of $85 \%$. As mentioned in the previous chapter, the electrolyser capacity is limited by the utilization rate of purely RE source of electricity. In the calculation, utilization rate directly affects the electrolyser capacity needed to supply the target hydrogen demand. To illustrate this, electrolyser capacity is sensitized with respect to utilization rate (Figure 4.3). If the utilization rate is improved, the required electrolyser capacity can be reduced. This implies that for purely RE-powered hydrogen production, optimizing electrolyser capacity can be achieved by improving the utilization rate of the RE source.

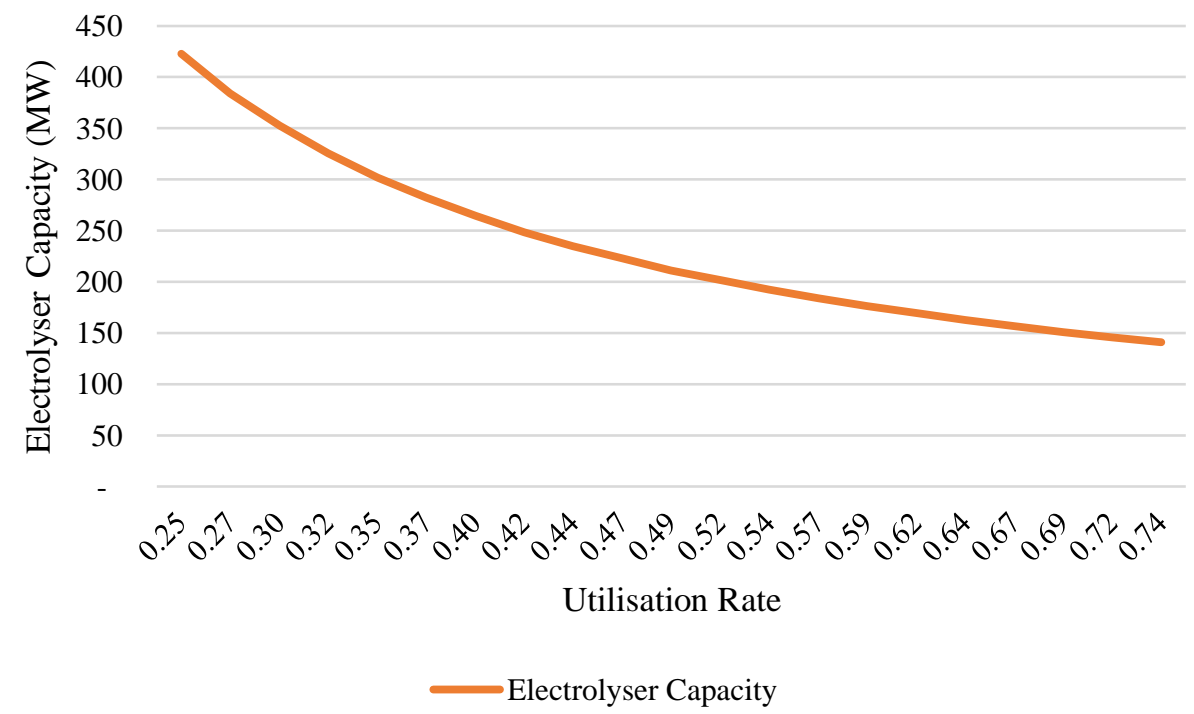

Figure 4.3. Sensitivity of electrolyser capacity to utilization rate 
Regional distribution of additional RE (Figure 4.4) shows that Wellington has the largest additional capacity composed of purely wind generation. The second largest additional capacity comes from Waikato. The takeaway from this QGIS generated map is the strategic location of the additional RE generation plants. Connection of additional RE to the grid is beneficial in extending power to regions of high hydrogen demand and regions without additional RE. RE in Wellington can support hydrogen production demand in both the North and South Islands, especially the Canterbury region. The Waikato and Bay of Plenty regions (Mount Maunganui) can support hydrogen demand in Auckland.

As shown in Table 3.9 in the previous chapter, additional RE consists mostly of wind, at 1862 MW or $79 \%$ of the total. Of the proposed RE generating plant, there are six wind, four hydroelectric (199 MW or $8 \%$ of consented yet unbuilt capacity) and 2 geothermal (303 MW or $13 \%$ of consented yet unbuilt capacity) projects. Significant additional wind energy will come from the Wellington and Manawatu-Wanganui regions which are known to have rich wind resources. At present, wind energy counts for a small percentage on the overall electricity grid mix (Electricity Authority, 2018). The proposed addition of wind energy plants indicates that the wind resource in such regions has not been exhausted yet. The same is true for other regions. Otago, which currently has a considerable hydro resource, also has a significant potential for wind energy. The West Coast has a potential for further development of hydro energy sources. These additional RE generation options may indicate that there are still untapped and unexhausted resources in New Zealand. This further suggests that a higher share of RE in the electricity grid, greater than present levels, can be achieved.

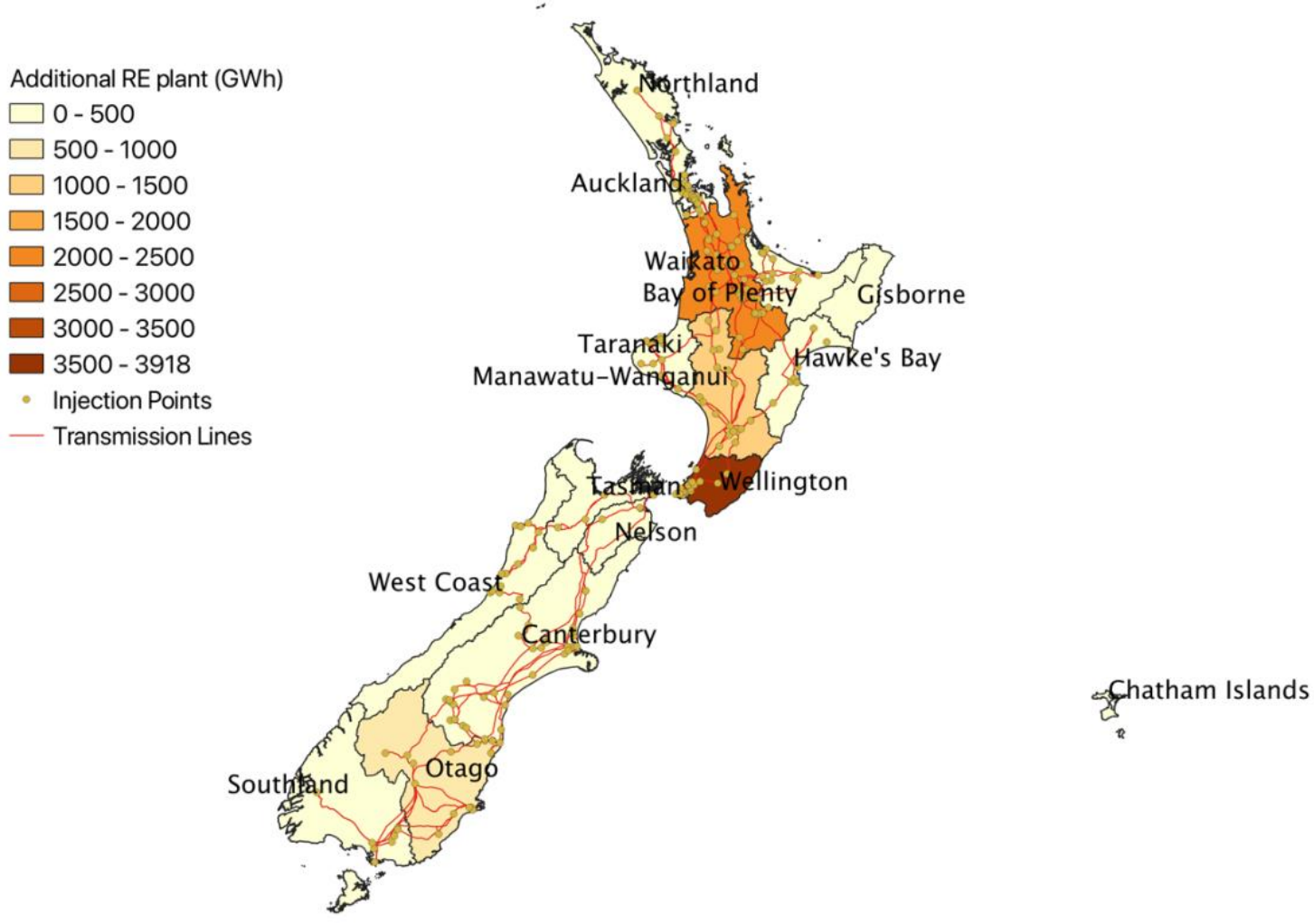

Figure 4.4. Regional distribution of additional RE 
Consented yet unbuilt RE totals $9,824 \mathrm{GWh}$. This is sufficient to power the hydrogen production electricity demand, which is $4,492 \mathrm{GWh}$ (inclusive of $4 \%$ grid network loss). This is a positive indication of green hydrogen cost competitiveness, because regions with abundant RE sources can produce more cost competitive green hydrogen (Hydrogen Council, 2020). However, the current study did not conduct a power matching scenario for regions of high hydrogen demand and regions with abundant RE supply. The current study also recognizes that these additional RE sources did not earn the status of approval by virtue of supplying power specifically for hydrogen production. It rather implies there is an opportunity for additional RE generation to consider green hydrogen outside of the wholesale electricity market.

\subsection{Hydrogen cost}

The calculated hydrogen price is NZ\$ 8.42/kg (see Section 3.4). The cost breakdown for this price is shown in Figure 4.5. This price is near to the Concept report estimate of NZ\$ 9.1/kg for large scale hydrogen production requiring new RE generation. Electricity cost counts for the largest portion of the hydrogen cost, occupying about $75 \%$ of total production costs. This is consistent with other hydrogen cost methodologies for electrolytic hydrogen. This is further illustrated in the sensitivity graph in Figure 4.6.

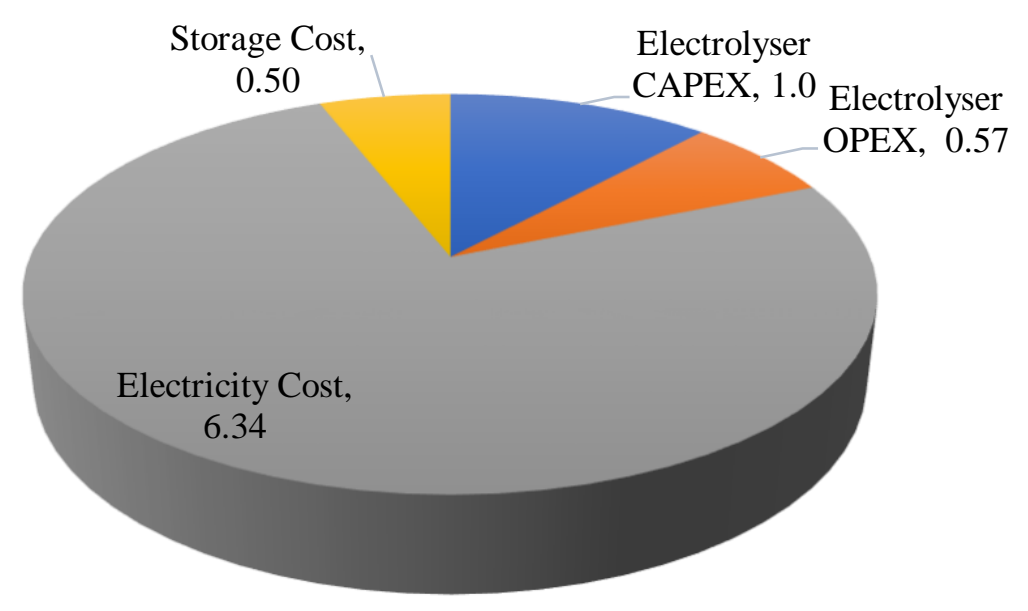

Figure 4.5. Hydrogen resultant costs in NZD/kg 


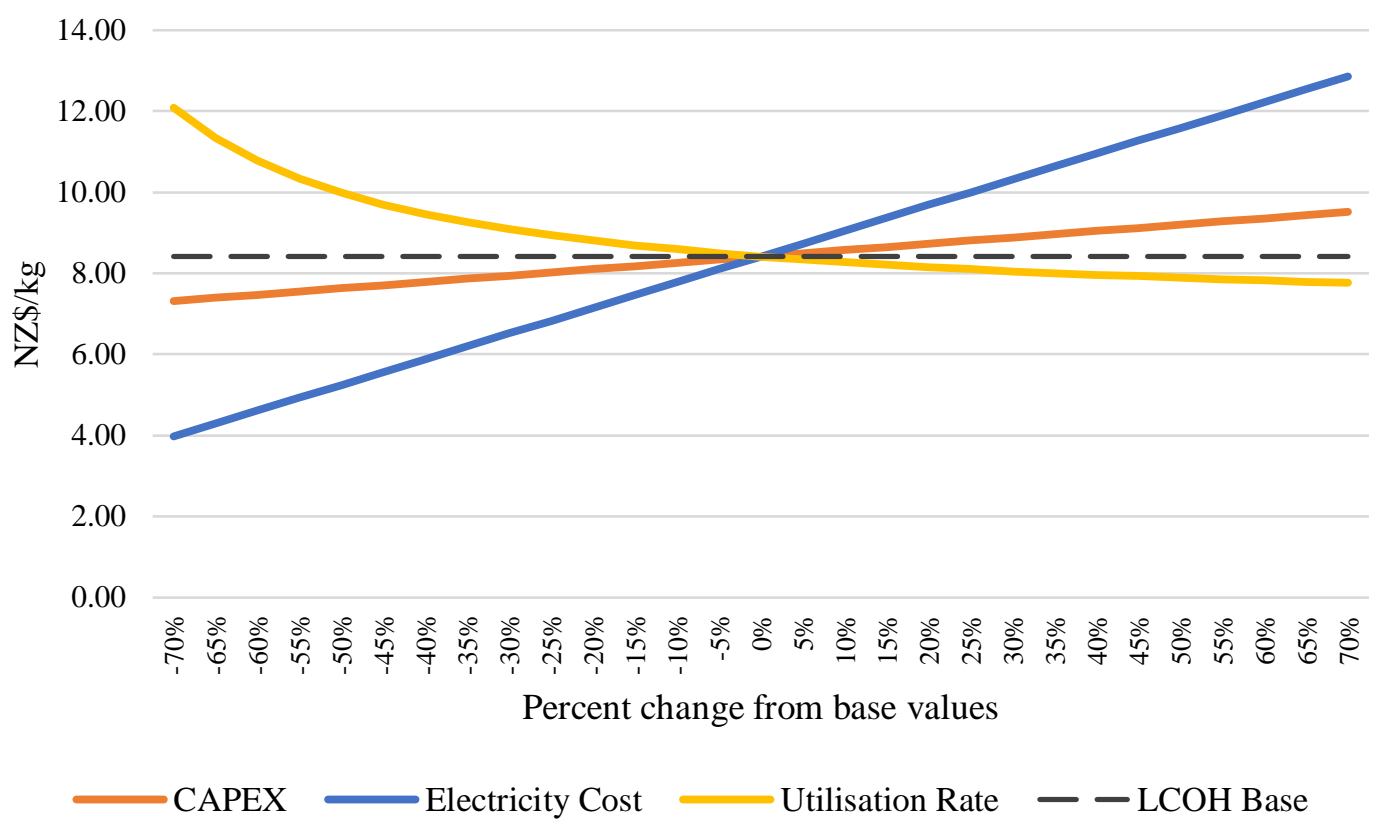

Figure 4.6. Hydrogen cost sensitivity graph

The sensitivity graph is intended to measure the degree of uncertainty of $\mathrm{LCOH}$ to the range of values of CAPEX, electricity cost, and utilisation rate. The sensitivity analysis employs a oneat-a-time or deterministic approach (Crosetto, Tarantola, \& Saltelli, 2000). In the LCOH calculation, the base values were NZ\$1400/kW for CAPEX, NZ\$100/MWh for electricity, and the utilisation rate is $85 \%$. The range of value of each parameter is adjusted by $5 \%$ increase and decrease from the base value. This is extended up to a $70 \%$ increase and decrease from base values.

Based on the graph, electricity cost is the most uncertain cost aspect of the $\mathrm{LCOH}$. This implies that changes in the cost of electricity will significantly affect hydrogen cost, three-fold compared to CAPEX. For the utilisation rate, the curved line shows that the $\mathrm{LCOH}$ will rise up at lower levels of utilisation but cannot go beyond the $100 \%$ mark. The greatest future cost reduction opportunity is reflected in the electricity cost. Should the hydrogen production be subjected to wholesale market operation, fluctuation in electricity price will make the cost of hydrogen highly unstable. Instability in hydrogen prices will reduce its economic competitiveness (Rahil \& Gammon, 2017). A fixed electricity price from a grid connected dedicated RE generating plant is therefore beneficial for hydrogen production.

\subsection{Cost reduction scenarios}

Three scenarios project the price of hydrogen in 10 to 20 years. Each scenario is crafted for a specific cost reduction of both CAPEX and electricity, as shown in Table 4.1. The cost reduction for CAPEX is 3\%, approximately equal to the projections made by Concept Consultancy (2019) and the Hydrogen Council (2020). This cost reduction figure is based on an increased production scale (up to $90 \mathrm{GW}$ of electrolytic hydrogen production capacity) and a $13-15 \%$ technology learning rate. Cost reduction for electricity is pegged at $4 \%$, reflective of the 
reduction of LCOE from onshore wind (Hydrogen Council, 2020). The third scenario describes the combined effect of reducing CAPEX and electricity costs.

Table 4.1. Cost reduction scenarios

\begin{tabular}{|l|l|}
\hline Scenario 1 & reduced CAPEX; steady electricity cost \\
\hline Scenario 2 & reduced electricity; steady CAPEX \\
\hline Scenario 3 & reduced capex and electricity \\
\hline
\end{tabular}

The cost reduction over the 10- and 20-year period is shown in Figure 4.7. The reduction in CAPEX alone (Scenario 1 ) will yield a cost reduction of NZ\$ 0.42/ kg in 10 years and NZ\$0.72/kg in 20 years. Significant reductions in the electricity cost (Scenario 2 ) will reduce LCOH by NZ\$ $2.13 / \mathrm{kg}$ in 10 years and NZ\$3.54/ kg in 20 years. The combined reduction of both CAPEX and electricity cost (Scenario 3 ) will yield the biggest cost reduction opportunity. This is simply the arithmetic sum of the individual cost reductions for both CAPEX and electricity. In the third scenario, the $\mathrm{LCOH}$ may be reduced by NZ\$2.54/kg in 10 years ( $30 \%$ reduction rate) and will go down by a further NZ\$4.26/kg in 20 years, more than $50 \%$ from the base value. This cost reduction estimate is approximately similar to the estimate in the Hydrogen Council (2020) report.

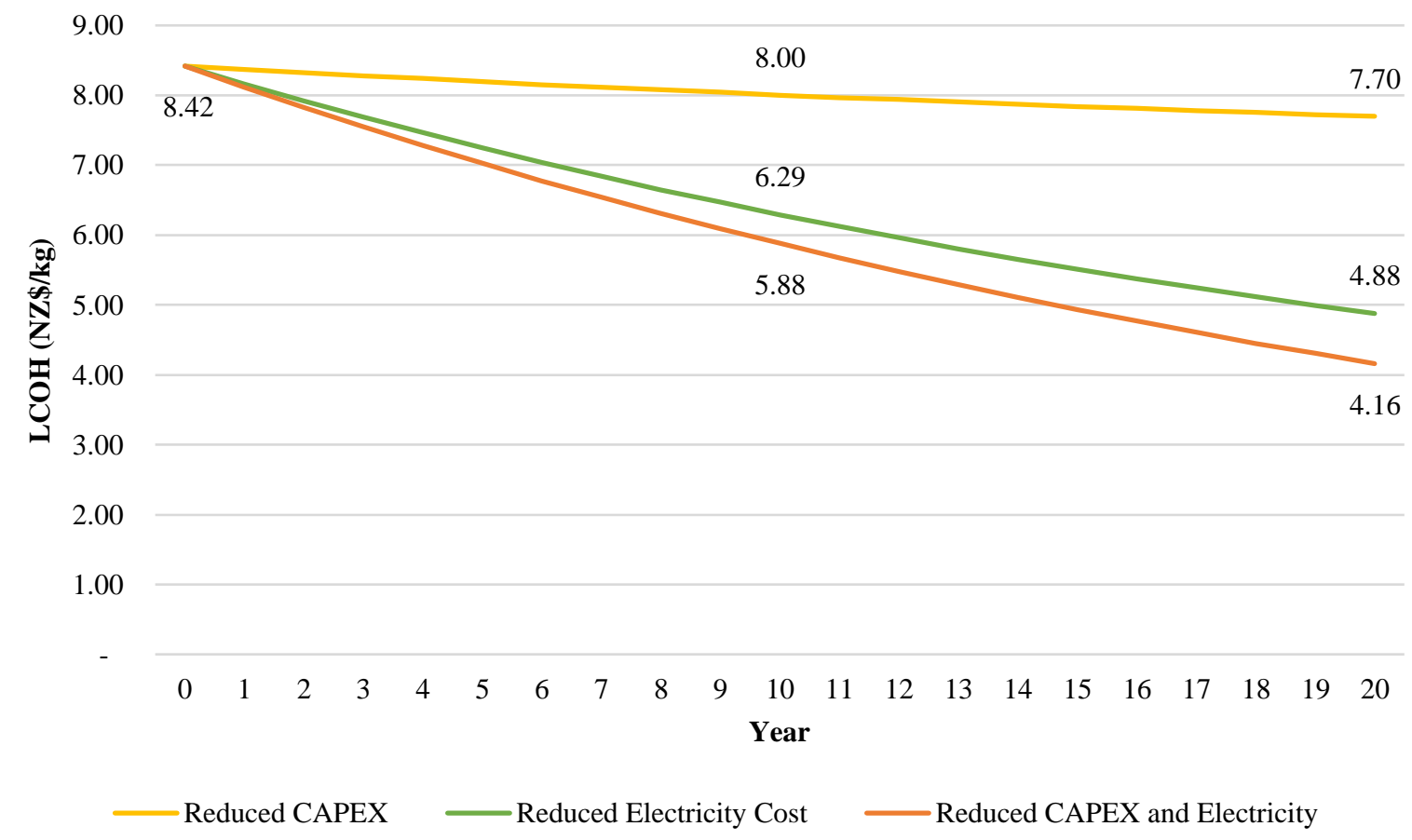

Figure 4.7. Hydrogen cost reduction scenarios

\subsection{Effect on ownership costs}

In order to examine the relative costs of diesel and fuel cell trucks, a sample calculation of the total cost of ownership (TCOO) is shown. The TCOO is composed of four segments, namely: fuel cost, vehicle capital cost, distance-based cost and other costs. The TCOO template is 
adopted from the Concept Consultancy (2019) report. The estimation of TCOO is done on an annual basis. The annual travel per VHVs is calculated from the total kilometres of all VHVs, which is equal to 885 million $\mathrm{km}$ (refer to Table 4.3 of previous chapter for calculation). This is divided by the number of VHVs in 2017, which is $12,193^{13}$. This implies that each VHV travels approximately 72,600 km per year, or around $200 \mathrm{~km}$ per day on average. Both diesel and hydrogen fuel costs are annualized by multiplying the cost per $\mathrm{km}$ by the travel $\mathrm{km}$ approximate for each VHV. The vehicle capital cost is payable within 6.5 years. The distancebased cost includes payload and refuelling penalties. Fuel cell trucks reflect a smaller distance-based cost compared to diesel trucks because of the relatively lighter weight of hydrogen fuel and fewer refuelling stops needed for hydrogen refuelling. Other costs involve drivers' salaries and other operational costs, which are equal for both diesel and fuel cell trucks (Concept Consultancy, 2019). Distance-based and other costs are the same for current and future cost TCOO scenarios. Table 4.2 specifies the assumptions taken for each segment of the TCOO.

Table 4.2. TCOO assumptions

\begin{tabular}{|l|l|}
\hline TCOO segment & Assumptions (units in NZ\$) \\
\hline Fuel cost & Diesel cost $=1.4 / \mathrm{I} ; \mathrm{H} 2$ cost $=8.42 / \mathrm{kg}$ \\
\hline Vehicle capital cost & Diesel truck $=175,000 ;$ Fuel cell truck $=500,000$ \\
\hline Distance-based cost & Diesel $=37,240 /$ year $;$ Fuel cell truck $=35,425 /$ year \\
\hline Other costs & $33,680 /$ year (equal for both vehicles) \\
\hline
\end{tabular}

Figure 4.8 shows the current TCOO of both diesel and fuel cell VHVs. For a diesel VHV, fuel is the largest share in the total cost, while the least cost is the vehicle capital. This is not the same with the fuel cell VHV, in which vehicle capital is the largest cost. This is because fuel cell technology is currently still expensive (Concept Consultancy, 2019).

\footnotetext{
${ }^{13}$ Number of trucks weighing more than 30 T. Data from https://www.transport.govt.nz/motresources/vehicle-fleet-statistics/
} 


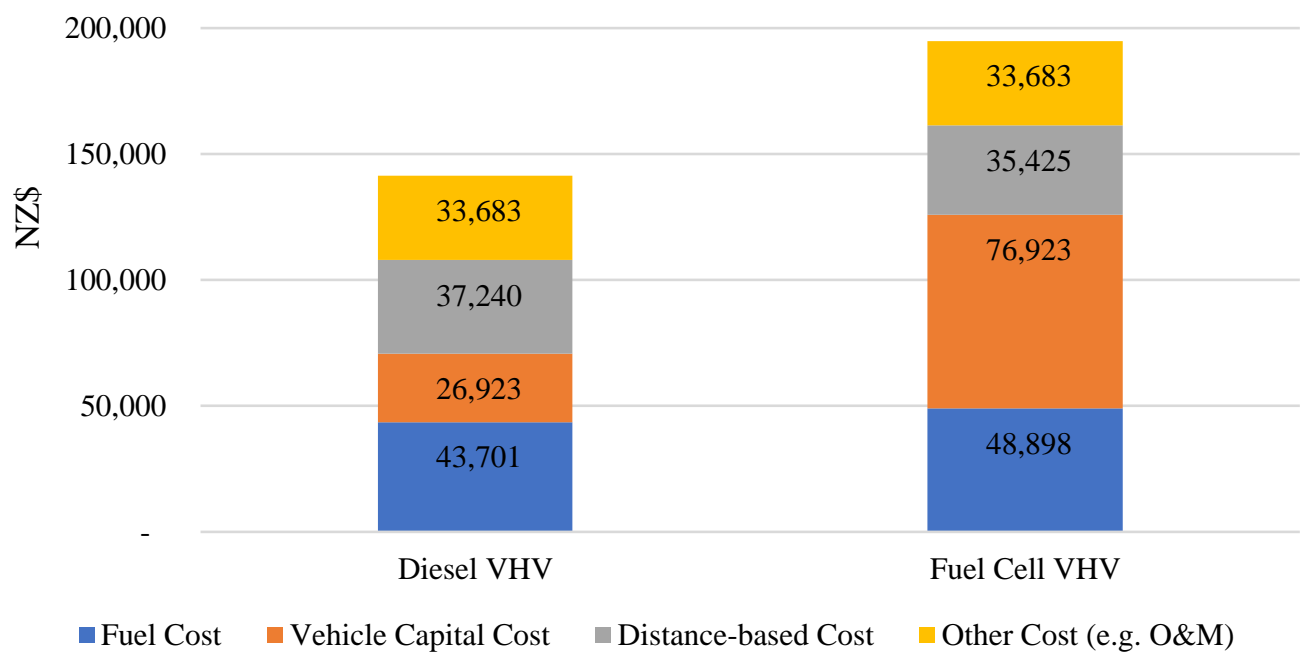

Figure 4.8. Current annual relative TCOO of VHVs

The future TCOO scenario is pegged at the 10th year (Figure 4.9). In this scenario, demand for VHVs is kept constant from the current scenario, which means that travel kilometres and number of VHVs are kept constant. Diesel fuel and vehicle costs are also kept constant. Cost reductions occur mainly on the hydrogen fuel cost and the fuel cell vehicle cost. The hydrogen cost reduces to NZ\$5.88/ $\mathrm{kg}$, as reflected in Figure 4.7 above. The fuel cell vehicle cost reduces to NZ\$375,000 from NZ\$500,000. The vehicle cost reduction estimates technology learning and an increased production scale in hydrogen and fuel cell technologies (Concept Consultancy, 2019). In order to achieve a breakeven TCOO for both diesel and fuel cell VHVs, a hypothetical carbon price margin is added. The carbon price equates to NZ\$19,400/year for diesel VHV. The carbon price illustrates the amount needed to be imposed on diesel VHVs in a year for hydrogen fuel cell VHVs to achieve TCOO cost parity. It can be in the form of an added diesel fuel or distance-based cost. 
200,000

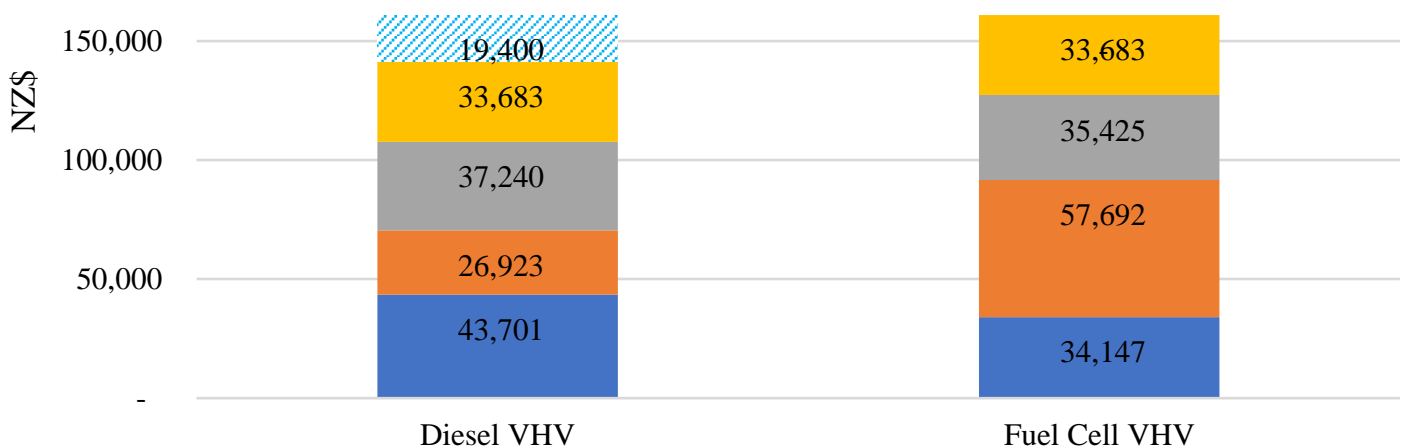

$\varpi$ Fuel Cost $₫$ Vehicle Capital Cost $₫$ Distance-based Cost $₫$ Other Cost (e.g. O\&M) $₫$ CO2 price margin

Figure 4.9. Future annual relative TCOO of VHVs

\subsection{Summary}

This chapter presented a discussion of the results, which were calculated in Chapter 3 , and addressed each research question, namely: hydrogen demand, additional renewable energy, and hydrogen cost. Discussion about possible cost reductions and their indicative effect on the total ownership costs was also provided. In summary, hydrogen results in more efficient conversion of energy to useful motive power than diesel for the same fuel demand volume. Energy from consented, yet unbuilt, renewable energy (RE) generation projects is more than the electrical energy required for hydrogen production. However, this study did not conduct a power matching analysis between regions of high hydrogen demand and regions with high RE potential. Possible grid effects of additional electricity demand from hydrogen production were also not evaluated. In the hydrogen cost calculation, electricity cost is the most significant cost aspect. Hydrogen cost reduction scenarios suggest that a reduction in electricity cost alone can significantly drive the cost of hydrogen. Even with CAPEX and electricity cost reductions in the future, a carbon price margin of NZ\$19,400/year is also needed in order to make fuel cell VHVs cost competitive with diesel VHVs. 


\section{Chapter 5 - Conclusions and recommendations}

This chapter presents the summary, limitations, conclusions and recommendations of the study.

This study examined the feasibility of green hydrogen as a transport fuel for the very heavy vehicle (VHV) fleet in New Zealand. It assumed that green hydrogen would be produced by water electrolysis using electricity from renewable energy (RE) generation. This study chose very heavy vehicles as a potential market for green hydrogen because it is considered as "lowhanging fruit" for hydrogen fuel where battery electrification is less feasible. It is based on large-scale, decentralized, embedded (dedicated) grid-connected hydrogen production using a polymer electrolytic membrane (PEM) electrolyser.

\subsection{Summary}

The analysis was done in three steps. First, hydrogen demand was calculated. This was undertaken by considering the complete displacement of diesel fuel consumption in VHVs. Second, the additional RE was evaluated in order to determine its sufficiency to supply electricity for green hydrogen production. The calculation was based on consented, yet unbuilt, RE projects. Finally, the hydrogen production cost was calculated using the concept of levelized cost. Sensitivity analyses, cost reduction scenarios, and the calculation of effect on truck ownership costs were also undertaken.

\subsection{Conclusions}

The results of this study indicate an overall green hydrogen demand for VHVs of 71 million $\mathrm{kg}$ or $8.5 \mathrm{PJ}$, smaller compared to the $14.7 \mathrm{PJ}$ of diesel fuel demand for the same VHV travel kilometres. Regions with greater populations and economic activities, such as Auckland and Canterbury, tend to have the largest demand for green hydrogen fuel. This study also established that the 9,824 GWh of RE electricity from consented, yet unbuilt, RE projects is greater than the electricity demand for green hydrogen production, which is estimated to be around $4,492 \mathrm{GWh}$. Wind is the largest RE source from the consented, yet unbuilt, projects, and is mostly concentrated in the Wellington region. A comparison of hydrogen demand and RE supply indicates a mismatch between regions of high hydrogen demand and high $\mathrm{RE}$ supply. The calculated levelized hydrogen cost is NZ\$ $8.42 / \mathrm{kg}$. This translates into NZ\$ $0.67 / \mathrm{km}$ of VHV travel cost, excluding retail margins. Electricity cost is also found to be the most sensitive cost parameter for green hydrogen production. A combined annual cost reduction rate of $3 \%$ for CAPEX and $4 \%$ for electricity indicates a hydrogen cost reduction of $30 \%$ in 10 years and more than $50 \%$ in 20 years. Despite potential cost reductions in fuel cell truck capital and green hydrogen fuel in the future, carbon pricing for diesel is still needed in order for hydrogen fuel cell trucks to become cost competitive with diesel.

\subsection{Limitations of the study}

There are five limitations in this study. First, there is no data available for actual travel kilometres for the VHVs, which were instead estimated from other indirect sources. Second, 
the reference for capital cost is based on capacity per kW costing for electrolysers and not per refuelling station. The current study recognises that each refuelling station can have more than one electrolyser unit. Third, there is no real cost reference for additional consented RE in New Zealand. The electricity cost base assumption of NZ\$100/MWh is taken from the marginal wholesale electricity prices in the New Zealand market. The technological advancement of RE is offset by material prices and shipping costs. The fourth limitation is the absence of a carbon cost mechanism in the calculations, whether distance-based or in addition to diesel cost, due to uncertainty. This is why a carbon price margin of NZ\$19,400 is provided in the future TCOO scenario for diesel VHVs. The carbon price margin illustrates the additional cost for a diesel VHV in order to achieve TCOO cost parity with a fuel cell VHV. Fifth, power matching analysis has been done only at an approximate level by identifying regions with high hydrogen demand and regions with high potential supply for RE electricity. This meant that transmission constraints have not been assessed in the current study. This also means that there is no assessment of the possible electricity grid impact of additional electricity demand for hydrogen production and potential electricity supply from consented, yet unbuilt, RE projects.

\subsection{Recommendations}

There are three recommendations from this study. First, carbon pricing for diesel must be implemented in order for green hydrogen transport fuel to be economically competitive. With the future implementation of the zero carbon bill in New Zealand, this can be made possible (New Zealand Productivity Commission, 2018). Second, power matching scenarios for regions with high hydrogen demand and regions with high potential supply for RE electricity must be assessed through further research. This includes identifying transmission constraints and grid impact assessments for possible grid stresses that both the additional electricity demand for hydrogen production demand and potential electricity supply from consented, yet unbuilt, RE projects can create. Third, the uptake of green hydrogen fuel will require exploration of potential policy interventions beyond carbon pricing for conventional fuels. The New Zealand government has been supportive of the promotion of electric vehicles. There have been fiscal and non-fiscal incentives for electric vehicles, such as privilege parking and access to charging stations. The government can do the same for hydrogen fuel cell vehicles, particularly for heavy vehicle freight operators (Ministry of Transport, 2019b). 


\section{References}

ANZ. (2019). ANZ NZ Truckometer August 2019, (August). Retrieved from https://www.anz.co.nz/content/dam/anzconz/documents/economics-and-marketresearch/2019/truckometer/ANZ-Truckometer-20190809.pdf

Bertuccioli, L., Chan, A., Hart, D., Lehner, F., Madden, B., \& Standen, E. (2014). Development of Water Electrolysis in the European Union. LC-GC North America. Retrieved from https://www.fch.europa.eu/sites/default/files/FCHJUElectrolysisStudy_FullReport (ID 199214).pdf

Bruce, S., Temminghoff, M., Hayward, J., Schmidt, E., Munnings, C., Palfreyman, D., \& Hartley, P. (2018). National Hydrogen Roadmap. Retrieved from https://www.csiro.au/en/Do-business/Futures/Reports/Hydrogen-Roadmap

BusinessNZ Energy Council. (2016). BEC 2050: A deep dive into 2030 energy targets for New Zealand, 8. Retrieved from https://www.bec.org.nz/_data/assets/pdf_file/0020/119009/A-deep-dive-into-2030energy-targets-for-New-Zealand.pdf

Collier, S., Ruehl, C., Yoon, S., Boriboonsomsin, K., Durbin, T. D., Scora, G., ... Herner, J. (2019). Impact of Heavy-Duty Diesel Truck Activity on Fuel Consumption and Its Implication for the Reduction of Greenhouse Gas Emissions. Transportation Research Record, 2673(3), 125-135. https://doi.org/10.1177/0361198119834548

Concept Consultancy. (2019). Hydrogen in New Zealand Report 2 - Analysis. Retrieved from http://www.concept.co.nz/uploads/2/5/5/4/25542442/h2_report2_analysis_v4.pdf

Crosetto, M., Tarantola, S., \& Saltelli, A. (2000). Sensitivity and uncertainty analysis in spatial modelling based on GIS. Agriculture, Ecosystems and Environment, 81(1), 71-79. https://doi.org/10.1016/S0167-8809(00)00169-9

Dell, R. M., Moseley, P. T., \& Rand, D. A. J. (2014). Chapter 8 - Hydrogen, Fuel Cells and Fuel Cell Vehicles. In R. M. Dell, P. T. Moseley, \& D. A. J. B. T.-T. S. R. T. Rand (Eds.) (pp. 260295). Boston: Academic Press. https://doi.org/https://doi.org/10.1016/B978-0-12404616-0.00008-6

Deloitte. (2017). Industry insight New Zealand ports and freight yearbook 2017. Retrieved from https://www2.deloitte.com/nz/en/pages/finance/articles/new-zealand-portsand-freight-yearbook.html

Electricity Authority. (2018). Electricity in New Zealand. Electricity Authority. Retrieved from https://www.ea.govt.nz/dmsdocument/20410-electricity-in-new-zealand

Energy Transitions Commission. (2018). Reaching net-zero carbon emissions from harder-toabate sectors by mid-century. Retrieved from https://www.ieta.org/resources/COP24/Misc Media Files/Dec7/SE16 (3).pdf

ENGINEERING, T., \& Hinicio. (2017). Study on Early Business Cases for H2 in Energy Storage 
and More Broadly Power To H2 Applications. EU Commission, (June), 228. Retrieved from

http://www.hinicio.com/inc/uploads/2017/07/P2H_Full_Study_FCHJU.pdf\%0Ahttp://w ww.fch.europa.eu/sites/default/files/P2H_Full_Study_FCHJU.pdf\%0Ahttp://www.hinici o.com/file/2018/06/P2H_Full_Study_FCHJU.pdf

ESORO. (2017). The world's first fuel cell heavy goods vehicle able to fulfill Coop's logistics requirements. ESORO. Retrieved from http://www.esoro.ch/deutsch/content/ aktuelles/images/Factsheet_Lastwagen_E.pdf

FCHJU. (2017). Development of Business Cases for Fuel Cells and Hydrogen Applications for Regions and Cities. Retrieved from https://www.fch.europa.eu/sites/default/files/171121_FCH2JU_ApplicationPackage_WG1_Heavy duty trucks \%28ID 2910560\%29 \%28ID 2911646\%29.pdf

Genç, G., Çelik, M., \& Serdar Genç, M. (2012). Cost analysis of wind-electrolyzer-fuel cell system for energy demand in Pnarbaş-Kayseri. International Journal of Hydrogen Energy, 37(17), 12158-12166. https://doi.org/10.1016/j.ijhydene.2012.05.058

Genç, M. S., Çelik, M., \& Karasu, I. (2012). A review on wind energy and wind-hydrogen production in Turkey: A case study of hydrogen production via electrolysis system supplied by wind energy conversion system in Central Anatolian Turkey. Renewable and Sustainable Energy Reviews, 16(9), 6631-6646. https://doi.org/10.1016/j.rser.2012.08.011

Greiner, C. J., KorpÅs, M., \& Holen, A. T. (2007). A Norwegian case study on the production of hydrogen from wind power. International Journal of Hydrogen Energy, 32(10-11), 1500-1507. https://doi.org/10.1016/j.ijhydene.2006.10.030

Gutiérrez-Martín, F., Confente, D., \& Guerra, I. (2010). Management of variable electricity loads in wind - Hydrogen systems: The case of a Spanish wind farm. International Journal of Hydrogen Energy, 35(14), 7329-7336. https://doi.org/10.1016/j.ijhydene.2010.04.181

Hinkley, J., Hayward, J., Mcnaughton, R., Gillespie, R., Matsumoto, A., Watt, M., \& Lovegrove, K. (2016). Cost assessment of hydrogen production from PV and electrolysis, (March), 1-35. Retrieved from http://arena.gov.au/files/2016/05/Assessment-of-the-cost-of-hydrogen-from-PV.pdf

Hydrogen Council. (2017). How hydrogen empowers the energy transition, (January), 28. https://doi.org/10.1109/TAP.2009.2035997

Hydrogen Council. (2020). Path to hydrogen competitiveness - A cost perspective, (January).

Hydrogenics. (2018). Hydrogenics Renewable Hydrogen Solutions. Retrieved from http://www.hydrogenics.com/wp-content/uploads/Renewable-HydrogenBrochure.pdf

Hyundai Motors New Zealand. (2019). World's first fleet of fuel cell electric trucks into 
commercial operation. Retrieved November 27, 2019, from

https://www.hyundai.co.nz/hyundai-motor-and-h2-energy-to-bring-the-world-s-first-

fleet-of-fuel-cell-electric-trucks-into-commercial-operation-

IEA. (2018). Oil 2018 - Analysis and Forecasts to 2023. Market Report Series.

IEA. (2019). Hydrogen. Retrieved May 31, 2019, from https://www.iea.org/topics/hydrogen/

IEA Hydrogen. (2015). Technology Roadmap - Hydrogen and Fuel Cells. Encyclopedia of Production and Manufacturing Management. https://doi.org/10.1007/1-4020-06128_961

IEA Hydrogen. (2017). Global Trends and Outlook for Hydrogen. Prepared by Mary-Rose de Valladares, (December), 20. https://doi.org/ISBN-13: 978-1-945951-07-7

International Energy Agency. (2017). Energy Policies of IEA Countries - New Zealand 2017 Review, 1-8. https://doi.org/10.1111/j.1475-6765.2009.01865.x

International Renewable Energy Agency (IRENA). (2018). Renewable Power Generation Costs in 2017. International Renewable Energy Agency. https://doi.org/10.1007/SpringerReference_7300

IRENA. (2018a). Hydrogen From Renewable Power: Technology outlook for the energy transition.

IRENA. (2018b). Renewable Power Generation Costs in 2017. International Renewable Energy Agency, Abu Dhabi. Retrieved from https://www.irena.org//media/Files/IRENA/Agency/Publication/2018/Jan/IRENA_2017_Power_Costs_2018.pd $\mathrm{f}$

IRENA. (2019). Renewable Power Generation Costs in 2018. International Renewable Energy Agency. https://doi.org/10.1007/SpringerReference_7300

Lee, D. Y., Elgowainy, A., Kotz, A., Vijayagopal, R., \& Marcinkoski, J. (2018). Life-cycle implications of hydrogen fuel cell electric vehicle technology for medium- and heavyduty trucks. Journal of Power Sources, 393(May), 217-229. https://doi.org/10.1016/j.jpowsour.2018.05.012

Lettenmeier, P. (2019). Efficiency - Electrolysis. Siemens AG, 1-8. Retrieved from https://assets.new.siemens.com/siemens/assets/api/uuid:139de890-44e1-453b-8176c3d45c905178/version:1558704999/white-paper-efficiency-en.pdf

Levene, J. I., Mann, M. K., Margolis, R. M., \& Milbrandt, A. (2007). An analysis of hydrogen production from renewable electricity sources. Solar Energy, 81(6), 773-780. https://doi.org/10.1016/j.solener.2006.10.005

Linnemann, J., \& Steinberger-Wilckens, R. (2007). Realistic costs of wind-hydrogen vehicle fuel production. International Journal of Hydrogen Energy, 32(10-11), 1492-1499. https://doi.org/10.1016/j.ijhydene.2006.10.029 
Loisel, R., Baranger, L., Chemouri, N., Spinu, S., \& Pardo, S. (2015). Economic evaluation of hybrid off-shore wind power and hydrogen storage system. International Journal of Hydrogen Energy, 40(21), 6727-6739. https://doi.org/10.1016/j.ijhydene.2015.03.117

Manage, M. N., Hodgson, D., Milligan, N., Simons, S. J. R., \& Brett, D. J. L. (2011). A technoeconomic appraisal of hydrogen generation and the case for solid oxide electrolyser cells. International Journal of Hydrogen Energy, 36(10), 5782-5796. https://doi.org/10.1016/j.ijhydene.2011.01.075

Mansilla, C., Louyrette, J., Albou, S., Bourasseau, C., \& Dautremont, S. (2013). Economic competitiveness of off-peak hydrogen production today - A european comparison. Energy, 55, 996-1001. https://doi.org/10.1016/j.energy.2013.03.022

MBIE. (2018). Energy in New Zealand 2018. Markets - Evidence and Insights Branch. Retrieved from https://www.mbie.govt.nz/assets/d7c93162b8/energy-in-nz-18.pdf

MBIE. (2019a). A vision for hydrogen in New Zealand. Energy Strategies for New Zealand, (September). Retrieved from https://www.mbie.govt.nz/building-and-energy/energyand-natural-resources/energy-strategies-for-new-zealand/

MBIE. (2019b). A vision for hydrogen in New Zealand. Retrieved April 9, 2019, from https://www.mbie.govt.nz/building-and-energy/energy-and-natural-resources/energystrategies-for-new-zealand/

MBIE. (2019c). Energy in New Zealand 2019. Markets - Evidence and Insights Branch, 15, 58.

Mehmeti, A., Angelis-Dimakis, A., Arampatzis, G., McPhail, S., \& Ulgiati, S. (2018). Life Cycle Assessment and Water Footprint of Hydrogen Production Methods: From Conventional to Emerging Technologies. Environments, 5(2), 24. https://doi.org/10.3390/environments5020024

Menanteau, P., Quéméré, M. M., Le Duigou, A., \& Le Bastard, S. (2011). An economic analysis of the production of hydrogen from wind-generated electricity for use in transport applications. Energy Policy, 39(5), 2957-2965. https://doi.org/10.1016/j.enpol.2011.03.005

Ministry of Transport. (2014). Executive Summary of National Freight Demands Study 2008, 1-18.

Ministry of Transport. (2019a). Light petrol and diesel vehicles comparison. Retrieved January 5, 2020, from https://www.transport.govt.nz/land/road-user-charges-ruc-andpetrol-excise-duty-ped/light-petrol-vs-diesel/

Ministry of Transport. (2019b). The Green Freight Project, (September).

Mohammadi, A., \& Mehrpooya, M. (2018). A comprehensive review on coupling different types of electrolyzer to renewable energy sources. Energy, 158, 632-655. https://doi.org/10.1016/j.energy.2018.06.073

New Zealand Productivity Commission. (2018). Low-emissions economy. Retrieved from 
https://www.productivity.govt.nz/sites/default/files/Productivity Commission_Lowemissions economy_Final Report_FINAL.pdf

NZTA. (2018). Average Annual Daily Traffic for all roads in New Zealand - data.govt.nz. Retrieved January 8, 2020, from https://data.govt.nz/datasetrequest/show/337

Olateju, B., Kumar, A., \& Secanell, M. (2016). A techno-economic assessment of large scale wind-hydrogen production with energy storage in Western Canada. International Journal of Hydrogen Energy, 41(21), 8755-8776.

https://doi.org/10.1016/j.ijhydene.2016.03.177

Parra, D., Valverde, L., Pino, F. J., \& Patel, M. K. (2019). A review on the role, cost and value of hydrogen energy systems for deep decarbonisation. Renewable and Sustainable Energy Reviews, 101(July 2018), 279-294. https://doi.org/10.1016/j.rser.2018.11.010

Pascuzzi, S., Anifantis, A. S., Blanco, I., \& Mugnozza, G. S. (2016). Electrolyzer performance analysis of an integrated hydrogen power system for greenhouse heating a case study. Sustainability (Switzerland), 8(7), 1-15. https://doi.org/10.3390/su8070629

Rahil, A., \& Gammon, R. (2017). Dispatchable hydrogen production at the forecourt for electricity demand shaping. Sustainability (Switzerland), 9(10). https://doi.org/10.3390/su9101785

Rahimi, S., Meratizaman, M., Monadizadeh, S., \& Amidpour, M. (2014). Techno-economic analysis of wind turbine-PEM (polymer electrolyte membrane) fuel cell hybrid system in standalone area. Energy, 67, 381-396. https://doi.org/10.1016/j.energy.2014.01.072

Saba, S. M., Müller, M., Robinius, M., \& Stolten, D. (2018). The investment costs of electrolysis - A comparison of cost studies from the past 30 years. International Journal of Hydrogen Energy, 43(3), 1209-1223. https://doi.org/10.1016/j.ijhydene.2017.11.115

Schmidt, O., Gambhir, A., Staffell, I., Hawkes, A., Nelson, J., \& Few, S. (2017). Future cost and performance of water electrolysis: An expert elicitation study. International Journal of Hydrogen Energy, 42(52), 30470-30492.

https://doi.org/10.1016/j.ijhydene.2017.10.045

Shi, X., Liao, X., \& Li, Y. (2020). Quantification of fresh water consumption and scarcity footprints of hydrogen from water electrolysis: A methodology framework. Renewable Energy, 154, 786-796. https://doi.org/10.1016/j.renene.2020.03.026

Siemens. (2018). Hydrogen Solutions. Siemens AG. Retrieved from https://new.siemens.com/global/en/products/energy/renewable-energy/hydrogensolutions.html

Siemens AG. (2017). SiLYZER 200, 8. https://doi.org/PDLD-B10004-01-7600

Thomas, D., Mertens, D., Meeus, M., Van der Laak, W., \& Francois, I. (2016). Power-to-Gas: Roadmap for Flanders, (October), 140.

Viktorsson, L., Heinonen, J. T., Skulason, J. B., \& Unnthorsson, R. (2017). A step towards the 
hydrogen economy - A life cycle cost analysis of a hydrogen refueling station. Energies, 10(6), 1-15. https://doi.org/10.3390/en10060763

Wulf, C., Linßen, J., \& Zapp, P. (2018). Review of power-to-gas projects in Europe. Energy Procedia, 155, 367-378. https://doi.org/10.1016/j.egypro.2018.11.041

Yodwong, B., Guilbert, D., Phattanasak, M., Kaewmanee, W., Hinaje, M., \& Vitale, G. (2020). AC-DC converters for electrolyzer applications: State of the art and future challenges. Electronics (Switzerland), 9(6). https://doi.org/10.3390/electronics9060912

Z Energy. (2019). Z Energy House View - Hydrogen, (December). Retrieved from https://z.co.nz/assets/Uploads/Z-House-View-Hydrogen-.pdf

Zolezzi, J. M., Garay, A., \& Reveco, M. (2010). Large scale hydrogen production from wind energy in the Magallanes area for consumption in the central zone of Chile. Journal of Power Sources, 195(24), 8236-8243. https://doi.org/10.1016/j.jpowsour.2009.12.060 